Article

\title{
Chemical Evolution of $\mathrm{Nb}$-Ta Oxides and Cassiterite in Phosphorus-Rich Albite-Spodumene Pegmatites in the Kangxiwa-Dahongliutan Pegmatite Field, Western Kunlun Orogen, China
}

\author{
Yonggang Feng ${ }^{1,2, *} \mathbb{D}$, Ting Liang ${ }^{1,2, *}$, Xiuqing Yang ${ }^{1,2}$, Ze Zhang ${ }^{1,2}$ and Yiqian Wang ${ }^{1,2}$ \\ 1 School of Earth Science and Resources, Chang'an University, Xi'an 710054, China; \\ xiuqing2008@126.com (X.Y.); 18209258176@163.com (Z.Z.); wyq940221@163.com (Y.W.) \\ 2 Laboratory of Mineralization and Dynamics, Chang'an University, Xi'an 710054, China \\ * Correspondence: ygfeng@chd.edu.cn (Y.F.); liangt@chd.edu.cn (T.L.)
}

Received: 30 January 2019; Accepted: 2 March 2019; Published: 8 March 2019

check for updates

\begin{abstract}
The Kangxiwa-Dahongliutan pegmatite field in the Western Kunlun Orogen, China contains numerous granitic pegmatites around a large granitic pluton (the Dahongliutan Granite with an age of ca. 220 to $217 \mathrm{Ma}$ ), mainly including barren garnet-, tourmaline-bearing pegmatites, Be-rich beryl-muscovite pegmatites, and $\mathrm{Li}$-, P-rich albite-spodumene pegmatites. The textures, major element contents, and trace element concentrations of columbite-group minerals (CGM) and cassiterite from three albite-spodumene pegmatites in the region were investigated using a combination of optical microscopy, SEM, EPMA and LA-ICP-MS. The CGM can be broadly classified into four types: (1) inclusions in cassiterite; (2) euhedral to subhedral crystals (commonly exhibiting oscillatory and/or sector zoning and coexisting with magmatic cassiterite); (3) anhedral aggregates; (4) tantalite-( $\mathrm{Fe})$-ferrowodginite $\left(\mathrm{FeSnTa}_{2} \mathrm{O}_{8}\right)$ intergrowths. The compositional variations of CGM and cassiterite are investigated on the mineral scale, in individual pegmatites and within the pegmatite group. The evolution of the pegmatites is also discussed. The variation of $\mathrm{Nb} / \mathrm{Ta}$ and $\mathrm{Zr} / \mathrm{Hf}$ ratios of the cassiterite mimics the $\mathrm{Nb}-\mathrm{Ta}$ and $\mathrm{Zr}$-Hf fractionation trends in many LCT pegmatites, indicating that these two ratios of cassiterite may bear meanings regarding the pegmatite evolution.
\end{abstract}

Keywords: albite-spodumene pegmatites; columbite-group minerals; cassiterite; Dahongliutan; chemical evolution of $\mathrm{Nb}$-Ta oxides

\section{Introduction}

Niobium and tantalum, considered as strategic metals, are widely used for manufacturing high-technology products [1,2] and columbite-group minerals (CGM) with a chemical formula $(\mathrm{Fe}, \mathrm{Mn})(\mathrm{Nb}, \mathrm{Ta})_{2} \mathrm{O}_{6}$ are the most important minerals in which $\mathrm{Nb}$ and $\mathrm{Ta}$ are major components. CGM commonly occurs in granitic pegmatites and highly evolved granites [3-6]. Recent studies show that chemistry of CGM possibly reflects the chemistry of magma sources and pegmatite melts [5-7] and that compositional variations of CGM can potentially reveal fractionation of pegmatite melts as well as hydrothermal evolution of pegmatites [8]. Most studies on CGM from granitic pegmatites focus on major and trace elements such as $\mathrm{Nb}, \mathrm{Ta}, \mathrm{Ti}, \mathrm{Sn}, \mathrm{Fe}$, and $\mathrm{Mn}$ [9-14], partly due to the limitations of analytical methods. Few studies paid attention to variation of trace element (including $\mathrm{Li}, \mathrm{Zr}, \mathrm{Hf}$, and REE) concentrations in CGM and its relationship with pegmatite evolution [5,7,8]. Therefore, more research needs to be carried out in order to understand the behavior of trace elements in CGM as well as in other $\mathrm{Nb}$-Ta oxides. 
Compared to CGM, chemistry of cassiterite from pegmatites has received little attention, though cassiterite from $\mathrm{Sn}$-rich granitoids, granite-related greisens and quartz veins has been extensively analyzed for both major and trace elements [15-18]. One possible reason may be the lack of cassiterite in many granitic pegmatites containing CGM and other $\mathrm{Nb}$-Ta oxides [7]. Cassiterite is structurally similar to CGM and significant $\mathrm{Nb}$ and Ta can enter cassiterite via a columbite substitution $(\mathrm{Fe}, \mathrm{Mn})^{2+}$ $+2(\mathrm{Nb}, \mathrm{Ta})^{5+}=3 \mathrm{Sn}^{4+}$ leading to formation of solid solutions between cassiterite and CGM $[9,19]$. It is expected that CGM and cassiterite in granitic pegmatites would influence the compositional variations of each other (i.e., $\mathrm{Nb} / \mathrm{Ta}$ ratios, $\mathrm{Zr} / \mathrm{Hf}$ ratios, and incorporation of trace elements).

The Dahongliutan albite-spodumene (AbSpd) pegmatites belong to the Kangxiwa-Dahongliutan pegmatite field that is located in the Western Kunlun Orogen, China and has been estimated to be a medium-sized deposit that contains 87,682 $\mathrm{t} \mathrm{Li}_{2} \mathrm{O}$ and $2684 \mathrm{t} \mathrm{BeO}$ [20,21]. According to [21], the Dahongliutan AbSpd pegmatites contain both CGM and cassiterite and thus provide a good opportunity to investigate chemical evolution of CGM and cassiterite as well as the compositional variations of these two minerals with evolution of lithium-cesium-tantalum (LCT) family pegmatites [22]. In this study, we combined EPMA and in situ LA-ICP-MS analyses of CGM, ferrowodginite, and cassiterite from the Dahongliutan AbSpd pegmatites with field and petrographic observation to explore the relationship between compositional variations of CGM and cassiterite and pegmatite evolution.

\section{Geological Setting}

The Western Kunlun Orogen (WKO) where the study area is located is regarded as an accretionary orogenic belt, which is bordered by the Tibetan Plateau to the south and the Tarim Block to the north (Figure 1a) [23-25]. From north to south, the southeast-trending Oytag-Kudi, Mazar-Kangxiwa and Hongshanhu-Qiaoertianshan sutures/faults subdivide the WKO into four major tectonic terranes: the North Kunlun, South Kunlun, Tianshuihai, and Karakorum terranes (Figure 1b) [21,26-30]. The WKO is dominated by Precambrian metamorphosed strata (mainly comprising metapelite, slate, marble, and dolomite), early Paleozoic strata (mainly composed of low-grade metamorphosed sandstone, chert and andesitic volcanic rocks), Permian and Triassic flysch formations, and early Paleozoic to Mesozic granites [23-25,31]. The subduction of the Proto- and Paleo-Tethys and collision between the above-mentioned terranes from early Paleozoic to early Mesozoic account for the main tectonic evolution history of the WKO [21,23,24,30,32]. The dynamics of the main sutures/faults in the WKO changed with time and has not been fully understood. According to [33], the formation of the Marzha-Kangxiwa suture represented the closure of the Proto-Tethys and this suture was superimposed by a large-scale strike-slip fault that was dextral during the early Paleozoic, but transformed to a sinistral strike-slip fault after the Triassic.

In this study, we focus on the NW-SE trending Tianshuihai terrane (TST) where the Kangxiwa-Dahongliutan pegmatite field is situated. The Mazar-Kangxiwa suture in the north and the Hongshanhu-Qianertianshan suture in the south separate this terrane from the South Kunlun and Karakorum terranes, respectively (Figure 1b) [25]. The TST is dominated by Paleoprotozoic Kangxiwa Group and Triassic Bayan Har Group, and Mesozoic Dahongliutan Granite and granitic pegmatites. The Kangxiwa Group is strongly deformed and mainly composed of biotite quartz schists, two-mica quartz schists, biotite quartz leptynite, felsic gneisses and marbles, whereas the Bayan Har Group is a suite of metamorphosed clastic rocks with lesser carbonate rocks [34,35]. The Dahongliutan Granite which is located south of the Marzha-Kangxiwa suture is intruded into both the Kangxiwa and Bayan Har groups and is likely a composite granite showing lithology varying from biotite monzogranite to two-mica granite with variable amounts of garnet, tourmaline, magnetite, apatite, and zircon (Figure 1b) [34]. Wei et al. [35] suggested that, the northeastern part of the Dahongliutan Granite was mainly monzogranite whereas the southwestern part of the pluton predominantly two-mica granite. Nevertheless, to date, the transitional zone between the two lithologies has not been identified yet. The mineralogy and geochemical features of the Dahongliutan Granite agree with a peraluminous 
S-type character [34]. In addition, the early-Mesozoic zircon SHRIMP U-Pb ages at ca. $220 \pm 2.2 \mathrm{Ma}$ to $217 \pm 2.2$ Ma point to its intrusion in a post-collisional tectonic regime [34].

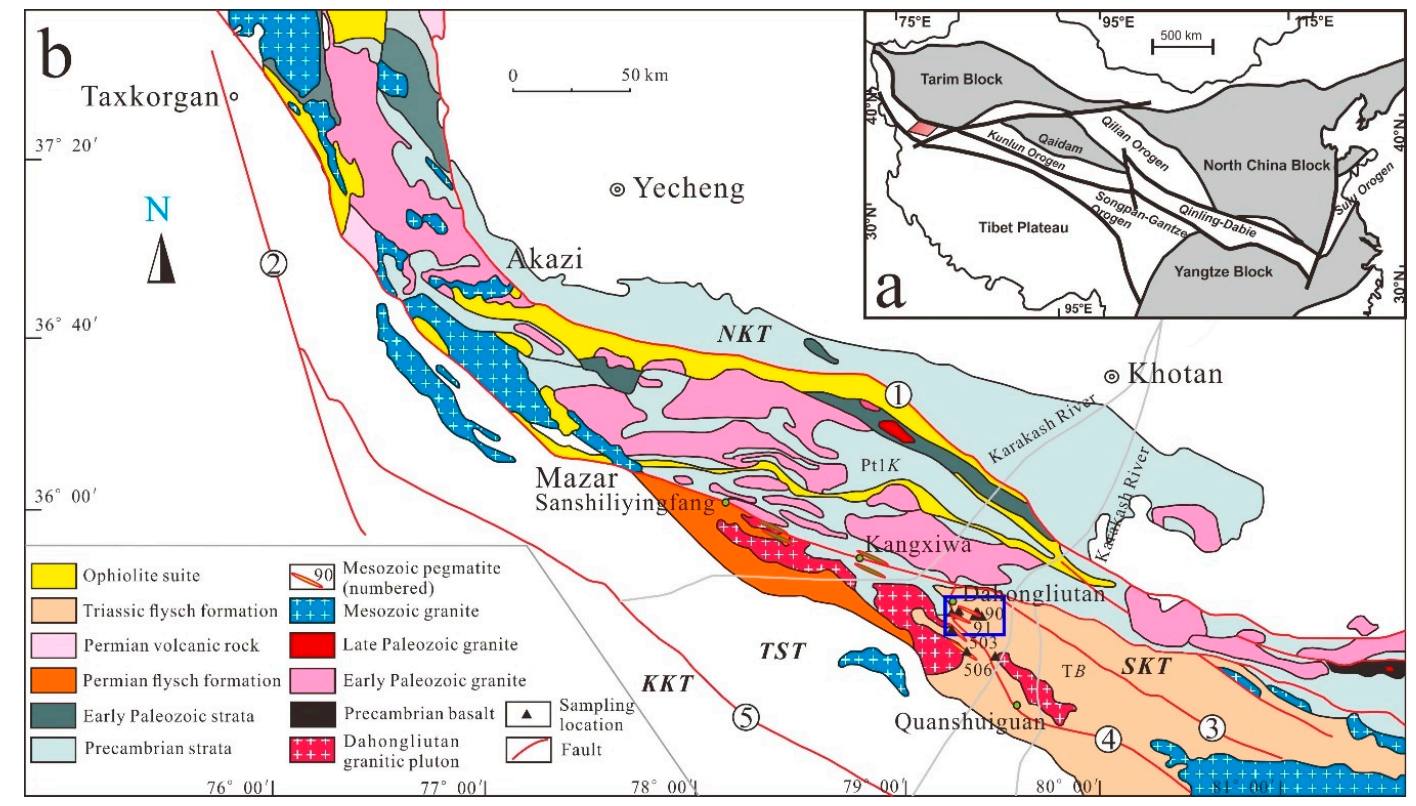

Figure 1. (a) Geological map showing the major tectonic units in China (after [36]) and the location of the study area (red quadrilateral) and (b) Geological map of the Western Kunlun Orogen (after [25,31]). Sutures and faults: 1-Oytag-Kudi Suture; 2-Karakorum Fault; 3-Mazha-Kangxiwa Suture; 4-Dahongliutan Fault; 5-Hongshanlu-Qiao'ertianshan Suture. Terranes: NKT—North Kunlun Terrane; SKT—South Kunlun Terrane; TST_-Tianshuihai Terrane; KKT_Karakorum Terrane. Strata: Pt1K_Paleoprotozoic Kangxiwa Group and TB-Triassic Bayan Har Group.

The Kangxiwa-Dahongliutan pegmatite field which contains more than 7000 pegmatite dikes extends from Sanshiliying to ca. $15 \mathrm{~km}$ southeast of Dahongliutan Village, along the Mazar-Kangxiwa Suture [20]. The pegmatite field mainly comprises three types of granitic pegmatites, namely, (i) barren garnet-, tourmaline-bearing microcline pegmatites (GrtTur pegmatites), (ii) Be-rich beryl-muscovite pegmatites (BrlMs pegmatites), and (iii) Li-, Nb-, and Ta-rich AbSpd pegmatites [21]. The AbSpd pegmatites are typical LCT-family pegmatites, according to the classification proposed by [22]. Most pegmatites occur as dikes and lenticular bodies with variable width (from $<1 \mathrm{~m}$ up to $>50 \mathrm{~m}$ ) and their orientation is mainly controlled by the Mazar-Kangxiwa suture and local faults [20,21]. The barren pegmatites are widely distributed along the Dahongliutan Granite, whereas the pegmatites with significantly economic Be mineralization and Li mineralization mainly occur at Kangxiwa and Dahongliutan and its nearby area. According to [20,21], the regional zoning of the pegmatites around the Dahongliutan Granite mimics the pattern for LCT-family pegmatite fields around their parental granitic plutons proposed by [37]. In general, GrtTur pegmatites are spatially closer to the granitic pluton than BrlMs pegmatites and AbSpd pegmatites at Dahongliutan [20]. Among the mineralized pegmatites, No. 90 and 91 pegmatites are the most important Li-rich pegmatites in terms of size [20,21]. Yan et al. [21] obtained a columbite U-Pb age of $211.9 \pm 2.4$ and a cassiterite U-Pb age of $218 \pm 12 \mathrm{Ma}$ for No. 90 AbSpd pegmatite using LA-ICP-MS. The Kangxiwa BrlMs pegmatite which accounts for the majority of Be mineralization in the Kangxiwa-Dahongliutan pegmatite field was dated at ca. $209.2 \pm 4.4 \mathrm{Ma}$ (our unpublished data), based on LA-ICP-MS U-Pb isotope dating on zircon (rim with oscillatory zoning). The geochronological studies on the Kangxiwa-Dahongliutan pegmatite field indicate that the BrlMs pegmatites and AbSpd pegmatites were likely coeval but were slightly younger than the Dahongliutan Granite. Based on the regional zoning of the pegmatites and geochronological 
data, Yan et al. [21] proposed that the Dahongliutan pegmatites may be evolved from the Dahongliutan granitic magma.

\section{Analytical Methods}

Field observations were made for examining the zonation patterns of No. 90, 91, and 503 pegmatites and a cross-section was drawn to demonstrate the relatively complete zoning of No. 90 pegmatite. All the following analyses were carried out at the Laboratory of Mineralization and Dynamics, Chang'an University. Optical microscopy was performed on doubly polished thin sections of pegmatite samples. In combination with optical microscopy, a FEI Quanta 650 Environment Scanning Electron Microscopy (ESEM) (Hillsboro, OR, USA) with a mounted INCA EDS (energy dispersive spectroscopy) was used for characterizing internal textures of rare metal-bearing minerals. The beam diameter and accelerating voltage were set at $5 \mu \mathrm{m}$ and $15 \mathrm{kV}$, respectively. Triphylite-lithiophilite series, CGM, cassiterite, and ferrowodginite were analyzed for major element concentrations using a JEOL JXA-8100 electron microprobe (Tokyo, Japan). The accelerating voltage and sample current were $15 \mathrm{kV}$ and $15 \mathrm{nA}$, respectively. The beam diameter was set to $2 \mu \mathrm{m}$. The summarization on the EPMA working condition is given in Supplementary Materials S1. The analytical precision for major oxide contents are better than 3\% (expressed as relative stand deviation). Summary of EPMA data for CGM and ferrowodginite and cassiterite is given in Tables 1 and 2, respectively. Complete EPMA dataset for CGM, ferrowodginite, and cassiterite are given in Supplementary Materials S2 and S3. Representative chemical compositions of triphylite-lithiophilite series are given in Table 3.

CGM, ferrowodginite, and cassiterite were analyzed for trace elements on a Photon Machines $193 \mathrm{~nm}$ excimer laser ablation system coupled with an Agilent 7700 ICP-MS (Santa Clara, CA, USA) at Chang'an University. The analyzed elemental isotopes included ${ }^{7} \mathrm{Li},{ }^{9} \mathrm{Be},{ }^{23} \mathrm{Na},{ }^{24} \mathrm{Mg},{ }^{27} \mathrm{Al},{ }^{29} \mathrm{Si},{ }^{31} \mathrm{P}$, ${ }^{44} \mathrm{Ca},{ }^{45} \mathrm{Sc},{ }^{49} \mathrm{Ti},{ }^{51} \mathrm{~V},{ }^{55} \mathrm{Mn},{ }^{56} \mathrm{Fe},{ }^{69} \mathrm{Ga},{ }^{85} \mathrm{Rb},{ }^{88} \mathrm{Sr},{ }^{89} \mathrm{Y},{ }^{90} \mathrm{Zr},{ }^{93} \mathrm{Nb},{ }^{118} \mathrm{Sn},{ }^{121} \mathrm{Sb},{ }^{133} \mathrm{Cs},{ }^{137} \mathrm{Ba},{ }^{139} \mathrm{La},{ }^{140} \mathrm{Ce}$, ${ }^{141} \mathrm{Pr},{ }^{146} \mathrm{Nd},{ }^{147} \mathrm{Sm},{ }^{149} \mathrm{Sm},{ }^{153} \mathrm{Eu},{ }^{157} \mathrm{Gd},{ }^{159} \mathrm{~Tb},{ }^{163} \mathrm{Dy},{ }^{165} \mathrm{Ho},{ }^{166} \mathrm{Er},{ }^{169} \mathrm{Tm},{ }^{172} \mathrm{Yb},{ }^{175} \mathrm{Lu},{ }^{177} \mathrm{Hf},{ }^{181} \mathrm{Ta}$, ${ }^{182} \mathrm{~W},{ }^{203} \mathrm{Tl},{ }^{206} \mathrm{~Pb},{ }^{209} \mathrm{Bi},{ }^{232} \mathrm{Th}$, and ${ }^{238} \mathrm{U}$. Spot analysis was performed and the spot size was $25 \mu \mathrm{m}$ in diameter. Positions of laser spots are close to the analytical spots of EPMA. The laser energy and repetition rate were $5.9 \mathrm{~J} / \mathrm{cm}^{2}$ and $10 \mathrm{~Hz}$, respectively. Helium gas was the carrier gas and NIST 610 was used as the primary external standard. Signal collecting time on gas background and sample were $10 \mathrm{~s}$ and $40 \mathrm{~s}$, respectively. Detailed descriptions regarding the accuracy and precision of this analysis are presented in Supplementary Materials S4. A software, Aabel NG2, was used for processing ICP spectra. Niobium concentration of CGM, Ta concentration of ferrowodginite, and Sn concentration of cassiterite based on EPMA analysis were used as the internal standards for calculating trace element concentrations in CGM, ferrowodginite and cassiterite, respectively. The results of LA-ICP-MS analyses of CGM and ferrowodginite and of cassiterite are presented in Tables 4 and 5.

\section{Results}

\subsection{Field Observations}

In this study, three AbSpd pegmatites near Dahongliutan were investigated, of which, No. 90 and 91 pegmatites are exposed ca. $1 \mathrm{~km}$ west of Dahongliutan while No. 503 AbSpd pegmatite ca. $10 \mathrm{~km}$ southeast of Dahongliutan, close to the southernmost margin of the Dahongliutan Granite (Figure 1b). The Li-rich pegmatites between these two localities were not investigated due to limited road access. In a plan view map, among the investigated pegmatites, No. 503 pegmatite is the nearest pegmatite of the Dahongliutian Granite while No. 90 pegmatite the farthest (Figure 1b). The strike of these three pegmatites is generally parallel to that of the metamorphosed strata (predominantly two-mica quartz schists) hosting the pegmatites (see Figure 2 for example). No. 90 and 91 pegmatites is SE-trending (ca. $115^{\circ}$ ) and dip southwest with a dip angle of ca. $70^{\circ}$. Both pegmatites show branching features and locally cross-cut the country rock from narrow angles (Figure 2a). 
According to [20], the AbSpd pegmatites were not well zoned in the Dahongliutan area. Nevertheless, our field observations show that No. 90 pegmatite is distinctly zoned, though No. 91 and 503 pegmatites show no clear zoning. The cross-section (Figure 2b) shows that from rim to core, the four lithological zones of No. 90 pegmatite include a Wall Zone (WZ) (locally strongly albitized), a spodumene-muscovite-quartz zone (SMQZ), a megacrystic spodumene-quartz zone and a Quartz Core. Close to the contact, the country rock contains abundant tourmaline.
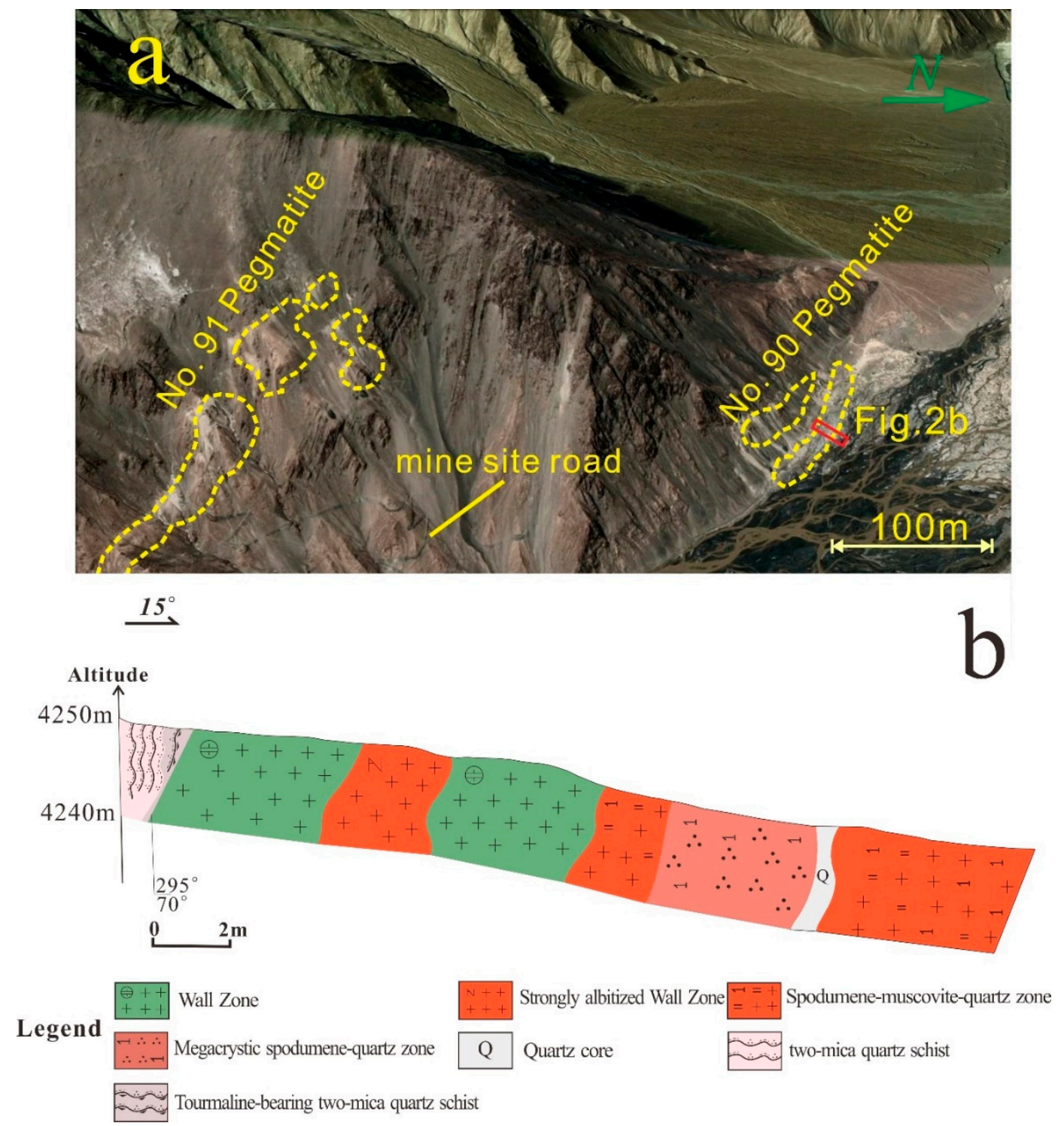

Figure 2. (a) Google Earth satellite image showing spatial relationship between No. 90 and No. 91 pegmatites near Dahongliutan (see the area in the blue box on Figure 1b) and (b) Cross section of No. 90 pegmatite showing four distinct lithologic zones.

The contact between the pegmatite and its country rock (two-mica quartz schists) is sharp (Figure 3a). The WZ is mainly composed of albite, quartz, and dark mineral (triphylite-lithiophilite series) that form dendritic aggregates growing towards the center of the pegmatite (Figure $3 b$ ) or form rounded aggregates showing no orientation (Figure 3c). The SMQZ is mainly composed of prismatic spodumene crystals (up to $35 \mathrm{~cm}$ long), coarse-grained albite, muscovite and quartz (Figure $3 \mathrm{~d}$ ). The megacrystic spodumene-quartz zone has a simple mineralogy and is dominated by euhedral, prismatic spodumene crystals (over $50 \mathrm{~cm}$ in length) and massive quartz (Figure 3e). The spodumene 
in the megacrystic spodumene-quartz zone commonly shows a dark rim (Figure 3f). The four zones are gradational into each other. When compared to No. 90 pegmatite, the mineralogy of No. 91 and No. 503 pegmatites is simple and dominated by coarse-grained spodumene, quartz and albite with lesser muscovite.
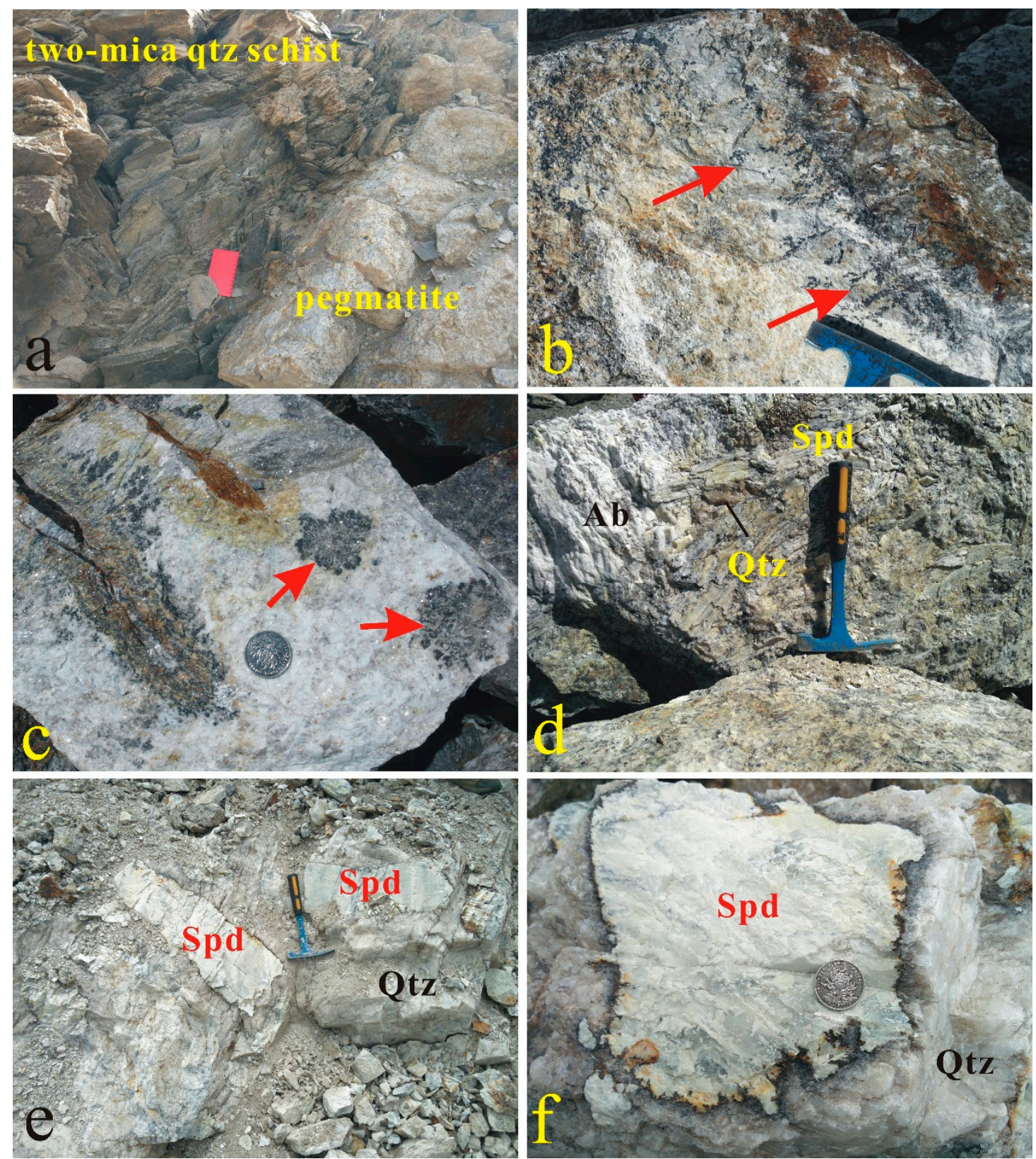

Figure 3. Field photos showing typical textures of No. 90 pegmatite. (a) the contact between the country rock (two-mica quartz schists) and the pegmatite. (b) oriented dendritic aggregates of dark minerals growing inwards from the contact zone between the Wall Zone of No. 90 pegmatite and country rock. (c) aggregate of dark minerals in the albitized Wall Zone. (d) typical mineralogy of the spodumene-muscovite-quartz zone. (e) megacrystic spodumene-quartz zone. (f) megacrystic spodumene showing a dark rim dominated by spodumene-quartz intergrowths (see Figure $4 \mathrm{e}, \mathrm{f}$ ). The length of the notebook, hammer and marker are $15 \mathrm{~cm}, 45 \mathrm{~cm}$, and $10 \mathrm{~cm}$, respectively. The diameter of the coin is $2 \mathrm{~cm}$. Mineral abbreviations: $\mathrm{Ab}=$ albite, $\mathrm{Qtz}=$ quartz, and Spd = spodumene. 


\subsection{Petrographic Observations}

The mineralogy of the two-mica quartz schists is dominated by medium- to coarse-grained biotite (10-20 vol. \%), muscovite ( $20-35$ vol. \%), quartz ( $20-35$ vol. \%), tourmaline (<1-15 vol. \%), and apatite (1-2 vol. \%) (Figure 4a). No. 91 and 503 pegmatites are mainly composed of albite, microcline, quartz, spodumene (30-50 vol. \%), amblygonite-montebrasite $\left(\mathrm{LiAl}\left(\mathrm{PO}_{4}\right)(\mathrm{F}, \mathrm{OH})\right)(15-30$ vol. \%), and muscovite (10-20 vol. \%) with lesser disseminated cassiterite (2-3 vol. \%), CGM (2-5 vol. \%), and tourmaline $(1 \%)$ and accessory zircon, beryl, and apatite. The well zoned No. 90 pegmatite exhibits a complicated mineralogy, compared with the other two pegmatites. In addition to the minerals within No. 91 and 503 pegmatites, No. 90 pegmatite contains triphylite-lithiophilite series and rare ferrowodginite-tantalite intergrowths. Triphylite-lithiophilite is abundant (10-15 vol. \%) in the WZ (Figure $3 \mathrm{~b}$ ) and SMQZ, and occurs as dendritic and rounded aggregates associated with fine-grained muscovite (Figure $4 \mathrm{~b}$ ), which makes this mineral species an important Li carrier in No. 90 pegmatite. Triphylite-lithiophilite series with such morphology was considered as a primary phase crystallizing from P-rich pegmatite melts [37-40]. Ferrowodginite-tantalite intergrowths are rare and mainly occur in the albite-rich part of the WZ of this pegmatite.

In all three pegmatites, spodumene (30-50 vol. \%) and amblygonite-montebrasite (15-30 vol. \%) are the predominant Li minerals. The two minerals commonly exhibit planar contact with each other (Figure 4c), indicating that both minerals were likely coevally formed. Two generations of albite can be observed: (1) coarse-grained magmatic albite that is mainly coeval with spodumene and (2) bladed albite (cleavelandite) formed during the albitization of the pegmatites (e.g., the strongly albitized WZ in Figure $3 b, c)$. Microcline is minor and commonly coarse-grained and euhedral. Cassiterite in all the pegmatites is coarse-grained (up to $\mathrm{cm}$ in diameter), euhedral and is yellowish to brown (Figure $4 \mathrm{~d}$ ). The majority of cassiterite and CGM are euhedral to subhedral and the two minerals are closely associated with each other (Figure 4d). Both euhedral to subhedral CGM and cassiterite coexist with coarse-grained quartz and albite. CGM also occurs as aggregates in No. 90 pegmatite. Tourmaline is mainly green to dark green schorl-foitite series and elbaite is rarely encountered. Common alteration minerals include secondary quartz, sericite, and chlorite. Moreover, spodumene in all three pegmatites shows a dark rim (e.g., the dark rim of the megacrystic spodumene in Figure 3f) that comprises intergrown spodumene and quartz (Figure 4e,f), similar to the symplectitic texture of spodumene-quartz intergrowths reported by [41]. Such intergrowth could be the product of growth at the expense of alkali feldspar [42] or the breakdown product of petalite [43]. Therefore, this second generation of spodumene is likely of hydrothermal origin. Acicular apatite commonly occurs as inclusions in the quartz of the spodumene-quartz intergrowths (Figure 4f). An even later generation of spodumene has also been spotted in all the three pegmatites. The third generation of spodumene occurs as fine-grained acicular aggregates in veinlets cross-cutting early mineral assemblages (Figure 4g,h).

\subsection{Important HFSE-Bearing Minerals and Classification of CGM}

Columbite-group minerals, cassiterite and zircon are important HFSE-bearing minerals in the investigated pegmatites. CGMs are divided to four types based on their occurrence and morphology revealed by back scattered electron (BSE) imaging and optical microscopy. Type 1 CGM is relatively rare (only spotted in No. 503 pegmatite) and occurs as mineral inclusions in coarse-grained subhedral to euhedral cassiterite. This CGM type is fine-grained (5-25 $\mu \mathrm{m}$ in length) and anhedral, showing no zoning. Type 2 CGM occurs as subhedral to euhedral single crystals (ca. 50-200 $\mu \mathrm{m}$ in length) and commonly coexists with coarse-grained cassiterite (Figure 4d). Both Type 2 CGM and cassiterite are associated with coarse-grained quartz, albite, spodumene, amblygonite, and muscovite. On BSE images, most Type 2 CGM shows sector and/or oscillatory zoning and increased Ta concentration from core to rim (Figure 5a). Some CGM of Type 2 show distorted oscillatory zoning and patchy patterns (Figure 5b). Type 2 CGM was frequently encountered in No. 91 and 503 pegmatites that show no lithological zonation. According to [21], Type 2 CGM also was mainly present in the spodumene-muscovite-quartz zone of No. 90 pegmatite. 


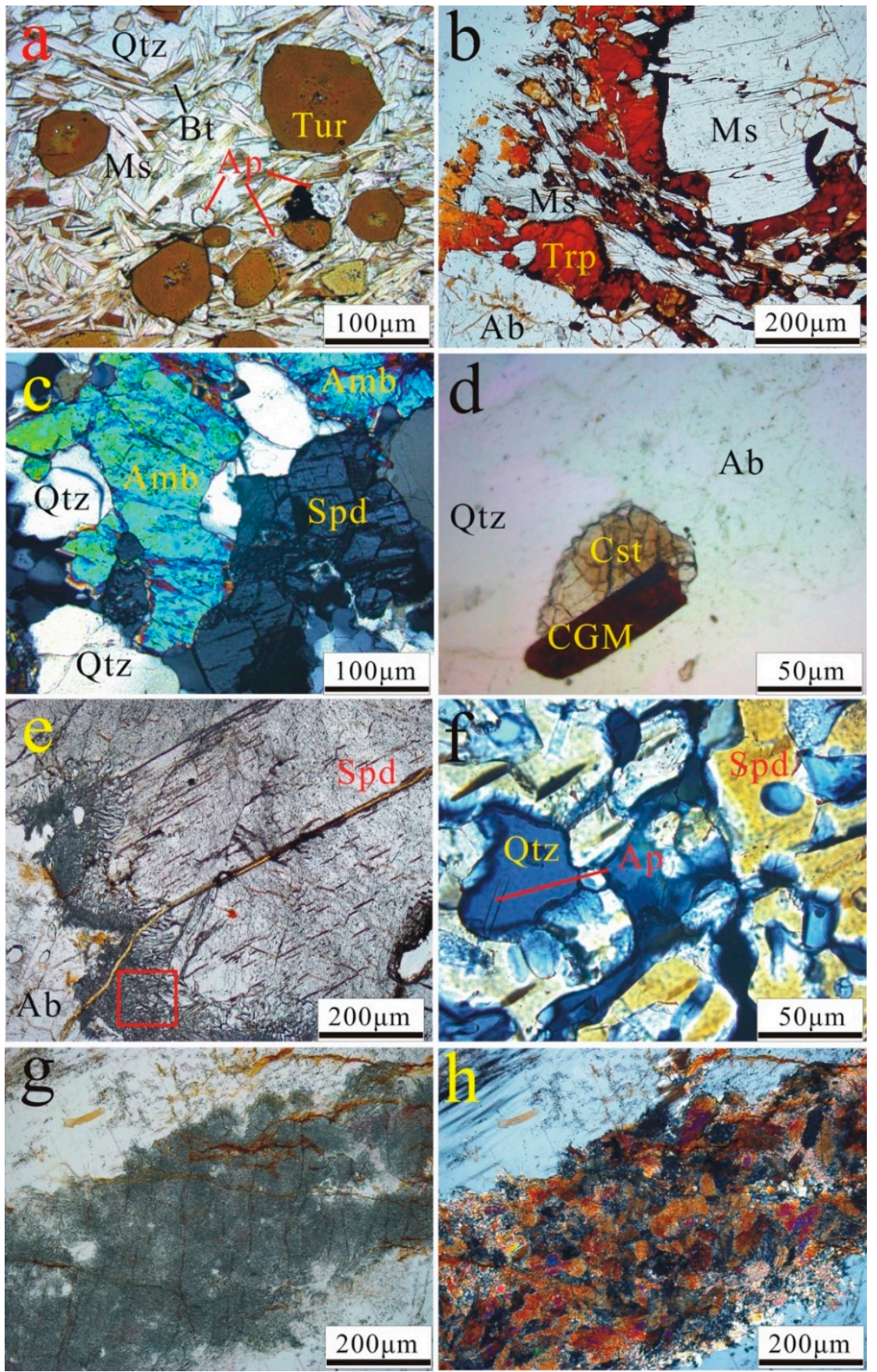

Figure 4. Photomicrographs showing typical mineralogy and textures in No. 90 pegmatite. (a) quartz + biotite + muscovite + tourmaline + apatite assemblage in the country rock. (b) red-brown triphylitelithiophilite series (showing a dark rim of Mn-, Fe-bearing oxides) aggregates intergrown with medium-grained muscovite in the Wall Zone. (c) textural relationships indicating that amblygonite and spodumene were likely coeval. (d) coexisting columbite-group mineral and cassiterite. (e) the dark rim of megacrystic spodumene which is characterized by fine-grained spodumene-quartz intergrowths similar to symplectic texture. (f) enlargement of the red box in (e) showing spodumene-quartz intergrowths and acicular apatite crystals in the quartz. Photomicrographs in plane-polarized light (g) and in cross-polarized light (h) showing late-stage fine-grained spodumene aggregates in veinlets cross-cutting coarse-grained albite. Abbreviations: Qtz = quartz, Spd = spodumene, Ms = muscovite, $\mathrm{Bt}=$ biotite, Tur $=$ tourmaline, $\mathrm{Amb}=$ amblygonite, $\mathrm{Ap}=$ apatite, $\mathrm{Ab}=$ albite, $\operatorname{Trp}=$ triphylite-lithiophilite series, $\mathrm{Cst}=$ cassiterite, and CGM = columbite-group minerals. 

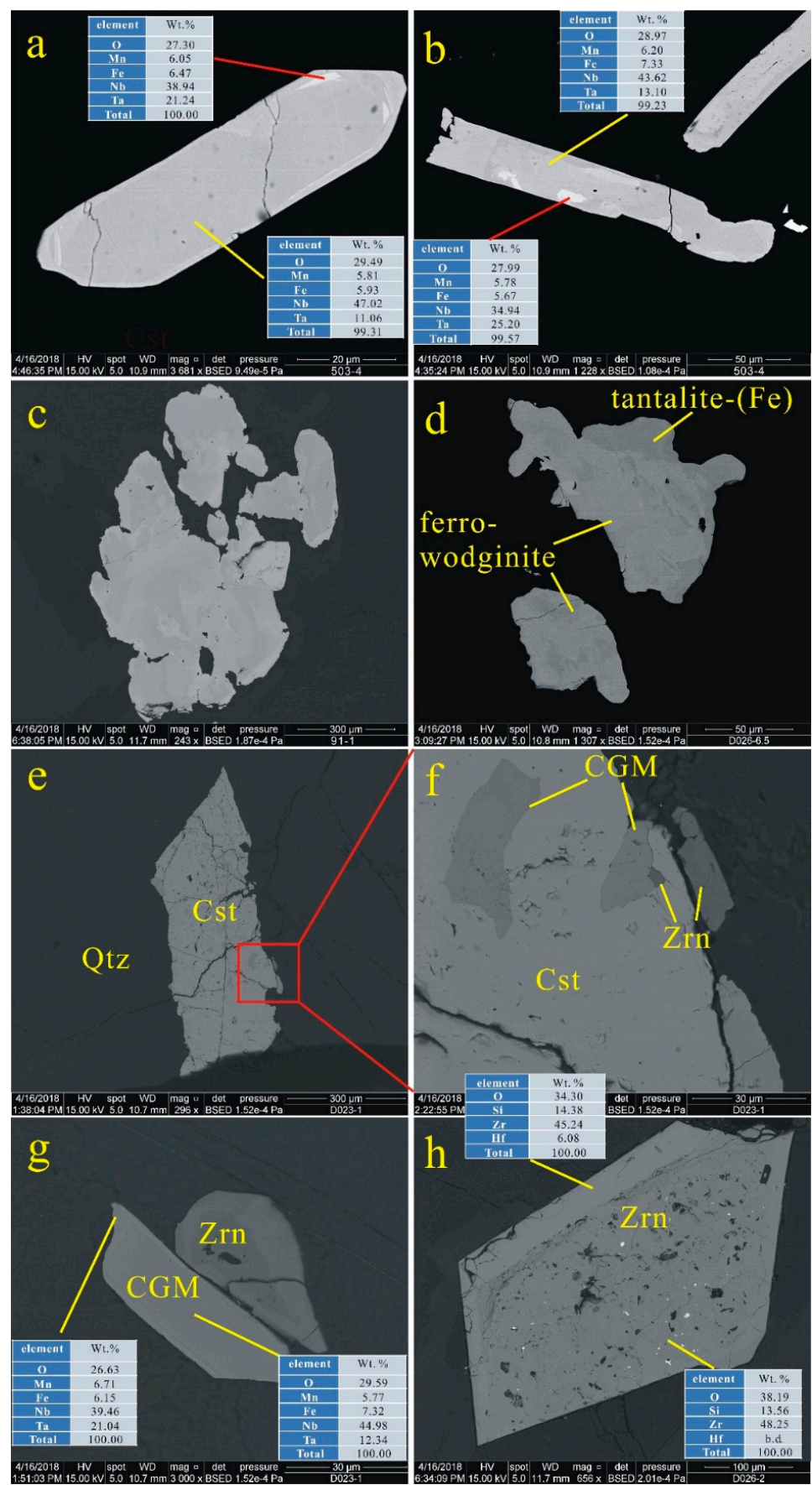

Figure 5. Back scattered electron (BSE) images of CGM, cassiterite and zircon in the Dahongliutan pegmatites. (a) euheral CGM (Type 2) showing sector zoning and increased Ta concentration from core to rim. (b) euhedral CGM (Type 2) showing distorted oscillatory zoning and patchy pattern. The bright phase contains much higher Ta than grey phases in the CGM. (c) anhedral CGM aggregate (Type 3) showing a patchy zoning with the Ta-Fe-rich domains (the brighter phase) at the margin of the crystal or along factures. (d) anhedral tantalite-(Fe)-ferrowodginite intergrowths only spotted in the Wall Zone of No. 90 pegmatite. (e,f) showing subhedral cassiterite containing CGM inclusions (Type 1) and zircon. The CGM inclusions show no orientation. (f) is the enlargement of the red box in (e). (g) euhedral CGM associated with coeval zircon. (h) euhedral zircon crystal in the Wall Zone of No. 90 pegmatite exhibiting a porous core (caused by dissolution-reprecipitation) and a relatively clean rim. Abbreviations: $\mathrm{Qtz}=$ quartz, $\mathrm{Cst}=$ cassiterite, $\mathrm{CGM}=$ columbite-group minerals, and Zrn = zircon. 
Type 3 CGM, which is mainly spotted in both the spodumene-muscovite-quartz and the megacrystic spodumene-quartz zones of No. 90 pegmatite, exists as anhedral aggregates in which individual grains show patchy domains with higher Ta and Fe (Figure 5c). The Ta-Fe-rich domains are commonly distributed at the margins of crystals or along fractures. Type 4 CGM occurs in anhedral tantalite-(Fe)-ferrowodginite intergrowths only spotted in the WZ of No. 90 pegmatite (Figure $5 \mathrm{~d}$ ). In addition, the minerals associated with types 3 and 4 CGM are similar to those associated with Type 2 CGM.

Cassiterite commonly coexists with Type 2 CGM and in some cases encloses Type 1 CGM and fine-grained zircon (Figure 5e,f). EPMA and LA-ICP-MS analyses show that cassiterite contains significant $\mathrm{Nb}$ and $\mathrm{Ta}$ (see the EPMA results for cassiterite below). Therefore, cassiterite should be considered as an important $\mathrm{Nb}$-, Ta-bearing phase.

Zircon is only present as an accessory phase and is generally subhedral to euhedral in the pegmatites. In some cases, zircon is closely associated with CGM (Figure 5g). Many zircon crystals exhibit a porous core and a relatively clean rim (Figure $5 \mathrm{~g}, \mathrm{~h}$ ), likely caused by dissolutionreprecipitation [44]. Compared with the core with almost no Hf, the zircon rim contains high Hf (6.08 wt. \%), based on EDS analysis (Figure 5h).

\subsection{EPMA}

\subsubsection{CGM and Ferrowodginite}

In No.503 Pegmatite, both Types 1 and 2 CGM are present. Only two EPMA data were obtained for Type 1 CGM that is rare. The rim of Type 1 CGM contains higher $\mathrm{Nb}_{2} \mathrm{O}_{5}$ and $\mathrm{WO}_{3}$ but lower $\mathrm{Ta}_{2} \mathrm{O}_{5}$ than the core (Table 1). The concentrations of FeOt and $\mathrm{MnO}$ in both the core and rim of Type 1 CGM are similar. On the columbite-tantalite quadrilateral proposed by [45], this types of CGM plot close to $\mathrm{Mn} /(\mathrm{Mn}+\mathrm{Fe})=0.5$ line and within the low $\mathrm{Ta} /(\mathrm{Ta}+\mathrm{Nb})$ field (Figure 6). The core and mantle of Type 2 CGM contain similar FeOt, $\mathrm{MnO}, \mathrm{Nb}_{2} \mathrm{O}_{5}$, and $\mathrm{Ta}_{2} \mathrm{O}_{5}$ contents but the mantle contains higher $\mathrm{WO}_{3}$, $\mathrm{SnO}_{2}$, and $\mathrm{TiO}_{2}$ contents (Table 1). The contents of FeOt and $\mathrm{MnO}$ in the rim are similar to those of the core and mantle. Although the rim of Type 2 CGM contains variable $\mathrm{Nb}_{2} \mathrm{O}_{5}(59.82 \pm 7.18 \mathrm{wt}$. \%) and $\mathrm{Ta}_{2} \mathrm{O}_{5}\left(18.26 \pm 7.61\right.$ wt. \%), the average $\mathrm{Nb}_{2} \mathrm{O}_{5}$ and $\mathrm{Ta}_{2} \mathrm{O}_{5}$ contents of the rim are higher than those of the core and mantle (Table 1). Similar to Type 1 CGM, Type 2 CGM from No. 503 pegmatite also plots close to $\mathrm{Mn} /(\mathrm{Mn}+\mathrm{Fe})=0.5$ line and within the low $\mathrm{Ta} /(\mathrm{Ta}+\mathrm{Nb})$ field (Figure 6). 
Table 1. Chemical composition (wt. \% oxides and a.p.f.u.) of CGM and ferrowodginite in the Dahongliutan albite-spodumene pegmatites.

\begin{tabular}{|c|c|c|c|c|c|c|c|c|c|c|c|c|c|c|}
\hline Pegmatite & No. 503 & No. 503 & No. 503 & & No. 503 & & No. 503 & & No. 503 & & No. 91 & & No. 91 & \\
\hline Type & 1 & 1 & 2 & & 2 & & 2 & & 2 & & 2 & & 2 & \\
\hline & & & mean & sd & mean & sd & mean & sd & mean & sd & mean & sd & mean & sd \\
\hline $\mathbf{n}$ & 1 & 1 & 10 & & 7 & & 8 & & 4 & & 4 & & 3 & \\
\hline Comments & CGM, c & CGM, $r$ & CGM, c & & $\begin{array}{c}\text { CGM, } \\
\text { m }\end{array}$ & & CGM, r & & $\begin{array}{c}\text { unzoned } \\
\text { CGM }\end{array}$ & & CGM, c & & CGM, r & \\
\hline $\mathrm{FeOt}$ & 10.67 & 10.83 & 10.25 & 0.89 & 10.35 & 0.90 & 10.17 & 0.65 & 11.25 & 0.09 & 11.58 & 1.40 & 10.91 & 0.50 \\
\hline $\mathrm{CaO}$ & 0.03 & 0.02 & 0.02 & 0.01 & 0.01 & 0.01 & 0.01 & 0.00 & 0.02 & n.a. & 0.00 & 0.00 & b.d. & n.a \\
\hline $\mathrm{MnO}$ & 9.32 & 9.61 & 9.80 & 0.90 & 9.33 & 1.07 & 9.70 & 0.55 & 8.99 & 0.28 & 8.03 & 1.84 & 6.92 & 2.45 \\
\hline $\mathrm{Al}_{2} \mathrm{O}_{3}$ & 0.00 & 0.04 & 0.02 & 0.02 & 0.03 & 0.02 & 0.02 & 0.02 & 0.03 & 0.01 & 0.02 & n.a. & 0.03 & 0.03 \\
\hline $\mathrm{Sc}_{2} \mathrm{O}_{3}$ & 0.08 & 0.08 & 0.10 & 0.04 & 0.12 & 0.05 & 0.12 & 0.08 & 0.07 & 0.06 & 0.17 & 0.10 & 0.33 & 0.18 \\
\hline $\mathrm{TiO}_{2}$ & 0.03 & 0.10 & 0.18 & 0.17 & 0.36 & 0.24 & 0.12 & 0.05 & 0.27 & 0.05 & 0.20 & 0.01 & 0.14 & 0.06 \\
\hline $\mathrm{SiO}_{2}$ & b.d. & b.d. & 0.02 & 0.01 & 0.00 & n.a. & 0.05 & 0.08 & b.d. & n.a. & 0.05 & 0.05 & 0.44 & 0.00 \\
\hline $\mathrm{SnO}_{2}$ & 0.06 & 0.13 & 0.09 & 0.06 & 0.20 & 0.11 & 0.06 & 0.04 & 0.08 & 0.02 & 0.14 & 0.05 & 0.12 & 0.04 \\
\hline $\mathrm{Nb}_{2} \mathrm{O}_{5}$ & 62.09 & 67.73 & 61.79 & 3.58 & 60.24 & 2.79 & 59.82 & 7.18 & 67.06 & 1.14 & 58.35 & 6.62 & 35.29 & 24.05 \\
\hline $\mathrm{Ta}_{2} \mathrm{O}_{5}$ & 14.58 & 9.23 & 15.13 & 2.82 & 16.37 & 3.01 & 18.26 & 7.61 & 9.55 & 0.24 & 19.83 & 7.90 & 43.56 & 26.35 \\
\hline $\mathrm{WO}_{3}$ & 0.27 & 0.15 & 0.28 & 0.17 & 0.37 & 0.11 & 0.35 & 0.13 & 0.41 & 0.07 & 0.18 & 0.04 & 0.31 & 0.11 \\
\hline $\mathrm{F}$ & b.d. & b.d. & 0.03 & 0.01 & b.d. & n.a. & 0.05 & n.a. & b.d. & n.a. & 0.12 & 0.06 & b.d. & n.a \\
\hline Total & 97.14 & 97.93 & 97.64 & 1.71 & 97.38 & 0.94 & 98.60 & 1.30 & 97.71 & 0.88 & 98.46 & 1.27 & 97.83 & 1.17 \\
\hline a.p.f.u. & & & & & & & & & & & & & & \\
\hline $\mathrm{Fe}^{2+}$ & 0.550 & 0.540 & 0.526 & 0.041 & 0.536 & 0.049 & 0.523 & 0.026 & 0.563 & 0.003 & 0.603 & 0.086 & 0.644 & 0.098 \\
\hline $\mathrm{Ca}^{2+}$ & 0.002 & 0.002 & 0.001 & 0.001 & 0.000 & 0.001 & 0.000 & 0.000 & 0.000 & 0.001 & 0.000 & 0.000 & 0.000 & 0.000 \\
\hline $\mathrm{Mn}^{2+}$ & 0.486 & 0.486 & 0.510 & 0.051 & 0.489 & 0.053 & 0.506 & 0.030 & 0.456 & 0.017 & 0.421 & 0.087 & 0.402 & 0.091 \\
\hline $\mathrm{Al}^{3+}$ & 0.000 & 0.003 & 0.001 & 0.001 & 0.003 & 0.002 & 0.001 & 0.001 & 0.002 & 0.001 & 0.000 & 0.001 & 0.002 & 0.002 \\
\hline $\mathrm{Sc}^{3+}$ & 0.004 & 0.004 & 0.006 & 0.002 & 0.006 & 0.003 & 0.007 & 0.005 & 0.004 & 0.003 & 0.009 & 0.006 & 0.021 & 0.013 \\
\hline $\mathrm{Ti}^{4+}$ & 0.001 & 0.004 & 0.008 & 0.008 & 0.017 & 0.011 & 0.006 & 0.002 & 0.012 & 0.002 & 0.009 & 0.001 & 0.008 & 0.004 \\
\hline $\mathrm{Si}^{4+}$ & 0.000 & 0.000 & 0.000 & 0.001 & 0.000 & 0.000 & 0.001 & 0.003 & 0.000 & 0.000 & 0.003 & 0.003 & 0.022 & 0.019 \\
\hline $\mathrm{Sn}^{4+}$ & 0.002 & 0.003 & 0.002 & 0.002 & 0.005 & 0.003 & 0.002 & 0.001 & 0.002 & 0.000 & 0.003 & 0.001 & 0.003 & 0.001 \\
\hline $\mathrm{Nb}^{5+}$ & 1.730 & 1.826 & 1.714 & 0.057 & 1.684 & 0.055 & 1.661 & 0.151 & 1.814 & 0.011 & 1.636 & 0.145 & 1.065 & 0.593 \\
\hline $\mathrm{Ta}^{5+}$ & 0.244 & $\begin{array}{l}1.020 \\
0.150\end{array}$ & 0.254 & 0.054 & 0.276 & 0.054 & 0.310 & 0.144 & 0.156 & 0.006 & 0.338 & 0.142 & 0.869 & 0.563 \\
\hline $\mathrm{W}^{6+}$ & 0.004 & 0.002 & 0.005 & 0.003 & 0.006 & 0.002 & 0.005 & 0.003 & 0.006 & 0.001 & 0.001 & 0.002 & 0.006 & 0.002 \\
\hline $\mathrm{F}^{-}$ & 0.000 & 0.000 & 0.001 & 0.002 & 0.000 & 0.000 & 0.001 & 0.004 & 0.000 & 0.000 & 0.012 & 0.016 & 0.000 & 0.000 \\
\hline $\mathrm{Mn} /(\mathrm{Mn}+\mathrm{Fe})$ & 0.47 & 0.47 & 0.49 & 0.04 & 0.48 & 0.05 & 0.49 & 0.03 & 0.45 & 0.01 & 0.41 & 0.08 & 0.38 & 0.09 \\
\hline $\mathrm{Ta} /(\mathrm{Ta}+\mathrm{Nb})$ & 0.12 & 0.08 & 0.13 & 0.03 & 0.14 & 0.03 & 0.16 & 0.07 & 0.08 & 0.00 & 0.17 & 0.07 & 0.45 & 0.30 \\
\hline
\end{tabular}


Table 1. Cont.

\begin{tabular}{|c|c|c|c|c|c|c|c|c|c|c|c|c|c|}
\hline Pegmatite & No. 90 * & & No. 90 & & No. 90 & & No. 90 & & No. 90 & & No. 90 & & No. 90 \\
\hline \multirow[t]{2}{*}{ Type } & 2 & & 3 & & 3 & & 3 & & 4 & & 4 & & 4 \\
\hline & mean & sd & mean & sd & mean & sd & mean & sd & mean & sd & mean & sd & \\
\hline $\mathbf{n}$ & 31 & & 3 & & 3 & & 4 & & 2 & & 2 & & 1 \\
\hline Comments & & & CGM, c & & $\begin{array}{c}\text { CGM, } \\
\text { m }\end{array}$ & & CGM, r & & fwdn, $r$ & & fwdn, c & & $\begin{array}{c}\text { unzoned } \\
\text { CGM }\end{array}$ \\
\hline $\mathrm{FeOt}$ & 12.17 & 0.71 & 2.09 & 0.28 & 1.49 & 0.18 & 5.16 & 2.27 & 9.05 & 0.40 & 9.43 & 0.14 & 10.79 \\
\hline $\mathrm{CaO}$ & n.a. & & 0.03 & 0.01 & 0.03 & 0.02 & 0.01 & 0.01 & 0.07 & 0.01 & 0.05 & 0.00 & 0.01 \\
\hline $\mathrm{MnO}$ & 5.73 & 0.91 & 16.69 & 0.53 & 17.13 & 0.30 & 12.78 & 2.85 & 3.68 & 0.12 & 3.67 & 0.05 & 5.50 \\
\hline $\mathrm{Al}_{2} \mathrm{O}_{3}$ & n.a. & & 0.02 & n.a. & 0.04 & 0.02 & 0.02 & 0.00 & 0.14 & 0.00 & 0.09 & 0.01 & b.d. \\
\hline $\mathrm{Sc}_{2} \mathrm{O}_{3}$ & 0.10 & 0.03 & 0.23 & 0.09 & 0.26 & 0.06 & 0.38 & 0.10 & 0.36 & 0.03 & 0.35 & 0.06 & 0.38 \\
\hline $\mathrm{TiO}_{2}$ & 0.70 & 0.11 & 0.12 & 0.13 & 0.00 & n.a. & 0.38 & 0.11 & 1.63 & 0.49 & 3.27 & 2.47 & 0.37 \\
\hline $\mathrm{SiO}_{2}$ & n.a. & & 0.13 & 0.08 & 0.11 & 0.03 & 0.19 & 0.09 & 0.44 & 0.01 & 0.42 & 0.01 & 0.41 \\
\hline $\mathrm{SnO}_{2}$ & 0.09 & 0.05 & 0.02 & 0.01 & 0.03 & 0.02 & 0.09 & 0.08 & 12.71 & 1.14 & 11.48 & 1.46 & 0.11 \\
\hline $\mathrm{Nb}_{2} \mathrm{O}_{5}$ & 64.12 & 4.42 & 49.25 & 7.46 & 47.25 & 4.87 & 39.23 & 7.67 & 9.64 & 0.76 & 10.14 & 0.94 & 22.92 \\
\hline $\mathrm{Ta}_{2} \mathrm{O}_{5}$ & 15.65 & 4.67 & 29.76 & 7.89 & 32.07 & 4.34 & 39.82 & 7.82 & 58.60 & 1.34 & 58.27 & 1.99 & 56.91 \\
\hline $\mathrm{WO}_{3}$ & 1.10 & 0.23 & 0.24 & 0.10 & 0.23 & 0.01 & 0.26 & 0.05 & 0.28 & 0.17 & 0.24 & 0.21 & 0.27 \\
\hline $\mathrm{F}$ & n.a. & & b.d. & n.a. & 0.11 & n.a. & 0.10 & 0.04 & b.d. & n.a. & b.d. & n.a. & 0.10 \\
\hline Total & 99.66 & 0.87 & 98.47 & 0.34 & 98.67 & 0.75 & 98.29 & 1.10 & 96.58 & 1.13 & 97.41 & 0.21 & 97.75 \\
\hline Fe $\mathrm{Fe}^{2+}$ & 0.613 & 0.038 & 0.113 & 0.012 & 0.081 & 0.009 & 0.298 & 0.135 & 0.598 & 0.027 & 0.608 & 0.007 & 0.675 \\
\hline $\mathrm{Ca}^{2+}$ & n.a. & & 0.002 & 0.001 & 0.002 & 0.001 & 0.001 & 0.001 & 0.006 & 0.000 & 0.004 & 0.000 & 0.001 \\
\hline $\mathrm{Mn}^{2+}$ & 0.292 & 0.043 & 0.916 & 0.010 & 0.949 & 0.023 & 0.734 & 0.134 & 0.246 & 0.008 & 0.240 & 0.009 & 0.348 \\
\hline $\mathrm{Al}^{3+}$ & n.a. & & 0.001 & 0.001 & 0.003 & 0.001 & 0.001 & 0.001 & 0.013 & 0.000 & 0.008 & 0.001 & 0.000 \\
\hline $\mathrm{Sc}^{3+}$ & 0.005 & 0.002 & 0.013 & 0.006 & 0.015 & 0.004 & 0.023 & 0.007 & 0.025 & 0.002 & 0.024 & 0.005 & 0.025 \\
\hline $\mathrm{Ti}^{4+}$ & 0.032 & 0.005 & 0.004 & 0.006 & 0.000 & 0.000 & 0.015 & 0.011 & 0.097 & 0.030 & 0.188 & 0.138 & 0.021 \\
\hline $\mathrm{Si}^{4+}$ & n.a. & & 0.006 & 0.006 & 0.007 & 0.002 & 0.013 & 0.006 & 0.035 & 0.001 & 0.032 & 0.002 & 0.030 \\
\hline $\mathrm{Sn}^{4+}$ & 0.003 & 0.001 & 0.000 & 0.000 & 0.001 & 0.001 & 0.002 & 0.002 & 0.400 & 0.035 & 0.354 & 0.055 & 0.003 \\
\hline $\mathrm{Nb}^{5+}$ & 1.744 & 0.088 & 1.439 & 0.171 & 1.395 & 0.102 & 1.204 & 0.186 & 0.345 & 0.028 & 0.353 & 0.023 & 0.774 \\
\hline $\mathrm{Ta}^{5+}$ & 0.258 & 0.083 & 0.528 & 0.161 & 0.572 & 0.095 & 0.742 & 0.165 & 1.260 & 0.027 & 1.223 & 0.075 & 1.157 \\
\hline $\mathrm{W}^{6+}$ & 0.017 & 0.004 & 0.004 & 0.002 & 0.004 & 0.000 & 0.005 & 0.001 & 0.006 & 0.004 & 0.005 & 0.004 & 0.005 \\
\hline $\mathrm{F}^{-}$ & n.a. & & 0.000 & 0.000 & 0.007 & 0.013 & 0.015 & 0.012 & 0.000 & 0.000 & 0.000 & 0.000 & 0.023 \\
\hline $\mathrm{Mn} /(\mathrm{Mn}+\mathrm{Fe})$ & 0.32 & 0.04 & 0.89 & 0.01 & 0.92 & 0.01 & 0.71 & 0.13 & 0.29 & 0.02 & 0.28 & 0.01 & 0.34 \\
\hline $\mathrm{Ta} /(\mathrm{Ta}+\mathrm{Nb})$ & 0.13 & 0.04 & 0.27 & 0.08 & 0.29 & 0.05 & 0.38 & 0.09 & 0.79 & 0.02 & 0.78 & 0.02 & 0.60 \\
\hline
\end{tabular}

Note: a.p.f.u. represents atoms per formula unit; CGM—columbite-group mineral, $\mathrm{fwdn}-$ ferrowodgenite; $\mathrm{b} . \mathrm{d}$. = below detection limit, and sd means standard deviation; $\mathrm{r}=$ rim,

$\mathrm{m}=$ mantle, and c = core; n.a. = "not available"; " $n$ " represents the number of analyses. Chemical formulae of CGM and wodginite were calculated based on 6 and 8 oxygen atoms,

respectively. Type 1: inclusions in cassiterite; Type 2: euhedral to subhedral single crystal; Type 3: mineral aggregates; Type 4: intergrowth with ferrowodginite. * Data cited from [21]. 
Table 2. Chemical composition (wt. \% oxides and a.p.f.u.) of cassiterite in the Dahongliutan albite-spodumene pegmatites.

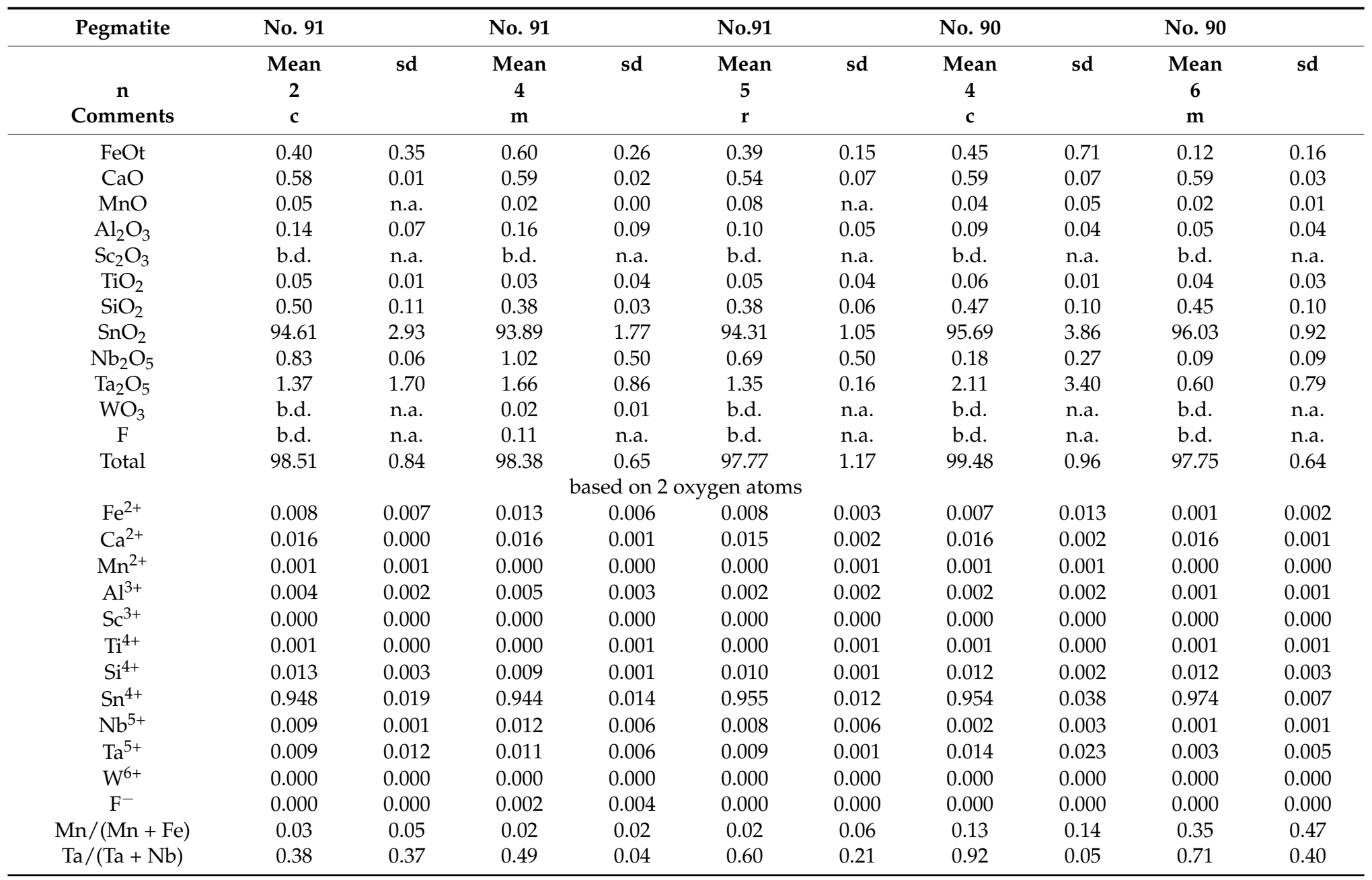


Table 2. Cont

\begin{tabular}{|c|c|c|c|c|c|c|c|c|}
\hline \multirow[t]{2}{*}{ Pegmatite } & \multirow{2}{*}{$\begin{array}{c}\text { No. } 90 \\
\text { mean }\end{array}$} & \multicolumn{3}{|c|}{ No. 503} & \multirow{2}{*}{$\begin{array}{c}\text { No. } 503 \\
\text { mean }\end{array}$} & \multicolumn{3}{|c|}{ No. 503} \\
\hline & & sd & mean & sd & & sd & mean & sd \\
\hline $\mathbf{n}$ & 5 & & 8 & & 7 & & 9 & \\
\hline Comments & $\mathbf{r}$ & & c & & $\mathbf{m}$ & & $\mathbf{r}$ & \\
\hline $\mathrm{FeOt}$ & 0.11 & 0.06 & 0.85 & 0.68 & 0.45 & 0.29 & 0.39 & 0.39 \\
\hline $\mathrm{CaO}$ & 0.58 & 0.04 & 0.49 & 0.05 & 0.54 & 0.05 & 0.50 & 0.07 \\
\hline $\mathrm{MnO}$ & b.d. & n.a. & 0.30 & 0.36 & 0.04 & 0.04 & 0.27 & 0.37 \\
\hline $\mathrm{Al}_{2} \mathrm{O}_{3}$ & 0.16 & n.a. & 0.04 & 0.05 & 0.07 & 0.06 & 0.10 & 0.10 \\
\hline $\mathrm{Sc}_{2} \mathrm{O}_{3}$ & b.d. & n.a. & b.d. & n.a. & b.d. & n.a. & b.d. & n.a. \\
\hline $\mathrm{TiO}_{2}$ & 0.07 & 0.06 & 0.11 & 0.16 & 0.13 & 0.07 & 0.07 & 0.09 \\
\hline $\mathrm{SiO}_{2}$ & 0.47 & 0.02 & 0.31 & 0.04 & 0.31 & 0.03 & 0.35 & 0.03 \\
\hline $\mathrm{SnO}_{2}$ & 96.26 & 0.63 & 90.87 & 4.47 & 94.45 & 1.43 & 92.98 & 4.58 \\
\hline $\mathrm{Nb}_{2} \mathrm{O}_{5}$ & 0.28 & 0.19 & 2.13 & 1.75 & 1.10 & 0.84 & 1.37 & 1.58 \\
\hline $\mathrm{Ta}_{2} \mathrm{O}_{5}$ & 0.47 & 0.28 & 3.49 & 1.67 & 0.39 & 0.39 & 1.83 & 2.32 \\
\hline $\mathrm{WO}_{3}$ & 0.07 & 0.05 & 0.15 & n.a. & 0.23 & n.a. & 0.03 & 0.01 \\
\hline F & 0.16 & n.a. & 0.24 & 0.17 & b.d. & n.a. & 0.18 & n.a. \\
\hline Total & 98.29 & 0.58 & 97.67 & 1.27 & 97.47 & 0.46 & 97.75 & 0.87 \\
\hline & & & based on 2 & gen ato & & & & \\
\hline $\mathrm{Fe}^{2+}$ & 0.002 & 0.001 & 0.018 & 0.014 & 0.010 & 0.006 & 0.008 & 0.008 \\
\hline $\mathrm{Ca}^{2+}$ & 0.016 & 0.001 & 0.013 & 0.001 & 0.015 & 0.001 & 0.014 & 0.002 \\
\hline $\mathrm{Mn}^{2+}$ & 0.000 & 0.000 & 0.006 & 0.008 & 0.001 & 0.001 & 0.004 & 0.007 \\
\hline $\mathrm{Al}^{3+}$ & 0.001 & 0.002 & 0.001 & 0.001 & 0.001 & 0.002 & 0.002 & 0.003 \\
\hline $\mathrm{Sc}^{3+}$ & 0.000 & 0.000 & 0.000 & 0.000 & 0.000 & 0.000 & 0.000 & 0.000 \\
\hline $\mathrm{Ti}^{4+}$ & 0.001 & 0.001 & 0.002 & 0.003 & 0.003 & 0.001 & 0.001 & 0.002 \\
\hline $\mathrm{Si}^{4+}$ & 0.012 & 0.001 & 0.008 & 0.001 & 0.008 & 0.001 & 0.009 & 0.001 \\
\hline $\mathrm{Sn}^{4+}$ & 0.970 & 0.008 & 0.921 & 0.048 & 0.957 & 0.019 & 0.941 & 0.049 \\
\hline $\mathrm{Nb}^{5+}$ & 0.003 & 0.002 & 0.024 & 0.019 & 0.013 & 0.010 & 0.016 & 0.018 \\
\hline $\mathrm{Ta}^{5+}$ & 0.003 & 0.002 & 0.017 & 0.015 & 0.003 & 0.003 & 0.013 & 0.016 \\
\hline $\mathrm{W}^{6+}$ & 0.000 & 0.000 & 0.000 & 0.000 & 0.000 & 0.001 & 0.000 & 0.000 \\
\hline $\mathrm{F}^{-}$ & 0.002 & 0.006 & 0.008 & 0.013 & 0.000 & 0.000 & 0.002 & 0.005 \\
\hline $\mathrm{Mn} /(\mathrm{Mn}+\mathrm{Fe})$ & 0.00 & 0.00 & 0.23 & 0.19 & 0.06 & 0.06 & 0.21 & 0.26 \\
\hline $\mathrm{Ta} /(\mathrm{Ta}+\mathrm{Nb})$ & 0.64 & 0.24 & 0.30 & 0.25 & 0.23 & 0.25 & 0.48 & 0.26 \\
\hline
\end{tabular}


Table 3. Representative compositions (wt. \% oxides and a.p.f.u.) of triphylite-lithiophilite series $\left(\mathrm{Li}(\mathrm{Fe}, \mathrm{Mn}) \mathrm{PO}_{4}\right)$ from No. 90 albite-spodumene pegmatite.

\begin{tabular}{|c|c|c|c|c|}
\hline \multirow[t]{2}{*}{ Zones } & \multicolumn{2}{|c|}{ Wall Zone } & \multicolumn{2}{|c|}{ Spd-Ms-Qtz Zone } \\
\hline & Mean & sd & Mean & sd \\
\hline $\mathbf{n}$ & 22 & & 18 & \\
\hline $\mathrm{MgO}$ & 0.82 & 0.07 & 0.47 & 0.05 \\
\hline $\mathrm{MnO}$ & 17.43 & 0.27 & 18.34 & 0.27 \\
\hline $\mathrm{P}_{2} \mathrm{O}_{5}$ & 44.10 & 0.97 & 43.91 & 0.63 \\
\hline $\mathrm{Al}_{2} \mathrm{O}_{3}$ & 0.02 & 0.01 & 0.01 & 0.01 \\
\hline $\mathrm{FeO}$ & 27.57 & 0.31 & 26.57 & 0.60 \\
\hline $\mathrm{Nb}_{2} \mathrm{O}_{5}$ & 0.10 & 0.06 & 0.09 & 0.05 \\
\hline $\mathrm{SiO}_{2}$ & 0.06 & 0.04 & 0.06 & 0.03 \\
\hline $\mathrm{Ta}_{2} \mathrm{O}_{5}$ & 0.05 & 0.05 & 0.04 & 0.03 \\
\hline $\mathrm{SnO}_{2}$ & 0.01 & 0.01 & 0.01 & 0.02 \\
\hline $\mathrm{WO}_{3}$ & 0.05 & 0.06 & 0.03 & 0.04 \\
\hline $\mathrm{CaO}$ & 0.31 & 0.22 & 0.36 & 0.23 \\
\hline $\mathrm{ZnO}$ & 0.40 & 0.12 & 0.25 & 0.06 \\
\hline $\mathrm{Sc}_{2} \mathrm{O}_{3}$ & 0.01 & 0.01 & 0.02 & 0.01 \\
\hline $\mathrm{TiO}_{2}$ & 0.005 & 0.006 & 0.006 & 0.007 \\
\hline Total & 90.84 & 0.83 & 90.11 & 0.67 \\
\hline * $\mathrm{Li}_{2} \mathrm{O}$ & 8.01 & 0.74 & 8.21 & 0.63 \\
\hline \multicolumn{5}{|c|}{ a.p.f.u. based on $P=1$} \\
\hline $\mathrm{Mg}^{2+}$ & 0.0327 & 0.0028 & 0.0187 & 0.0020 \\
\hline $\mathrm{Mn}^{2+}$ & 0.3955 & 0.0082 & 0.4178 & 0.0070 \\
\hline $\mathrm{P}^{5+}$ & 1.0000 & 0.0000 & 1.0000 & 0.0000 \\
\hline $\mathrm{Al}^{3+}$ & 0.0004 & 0.0004 & 0.0003 & 0.0004 \\
\hline $\mathrm{Fe}^{2+}$ & 0.6179 & 0.0176 & 0.5981 & 0.0187 \\
\hline $\mathrm{Nb}^{5+}$ & 0.0009 & 0.0008 & 0.0010 & 0.0007 \\
\hline $\mathrm{Si}^{4+}$ & 0.0016 & 0.0010 & 0.0015 & 0.0008 \\
\hline $\mathrm{Ta}^{5+}$ & 0.0002 & 0.0003 & 0.0001 & 0.0002 \\
\hline $\mathrm{Sn}^{4+}$ & 0.0000 & 0.0001 & 0.0001 & 0.0001 \\
\hline$W^{6+}$ & 0.0002 & 0.0004 & 0.0001 & 0.0002 \\
\hline $\mathrm{Ca}^{2+}$ & 0.0089 & 0.0065 & 0.0106 & 0.0067 \\
\hline $\mathrm{Zn}^{2+}$ & 0.0080 & 0.0025 & 0.0051 & 0.0013 \\
\hline $\mathrm{Sc}^{3+}$ & 0.0001 & 0.0002 & 0.0003 & 0.0003 \\
\hline $\mathrm{Ti}^{4+}$ & 0.0000 & 0.0001 & 0.0001 & 0.0001 \\
\hline $\mathrm{O}^{2-}$ & 3.5690 & 0.0308 & 3.5560 & 0.0288 \\
\hline O difference & 0.4310 & 0.0308 & 0.4440 & 0.0288 \\
\hline $\mathrm{Li}^{+}$ & 0.8621 & 0.0616 & 0.8881 & 0.0575 \\
\hline
\end{tabular}

Note: " $\mathrm{n}$ " represents the number of EPMA spot analyses. Abbreviations: $\mathrm{sd}=$ standard deviation, Spd = spodumene, $\mathrm{Ms}=$ muscovite, and Qtz $=$ quartz. ${ }^{*}$ Lithium contents are calculated based on the ideal chemical formula of triphylite-lithiophilite series and charge balance. 


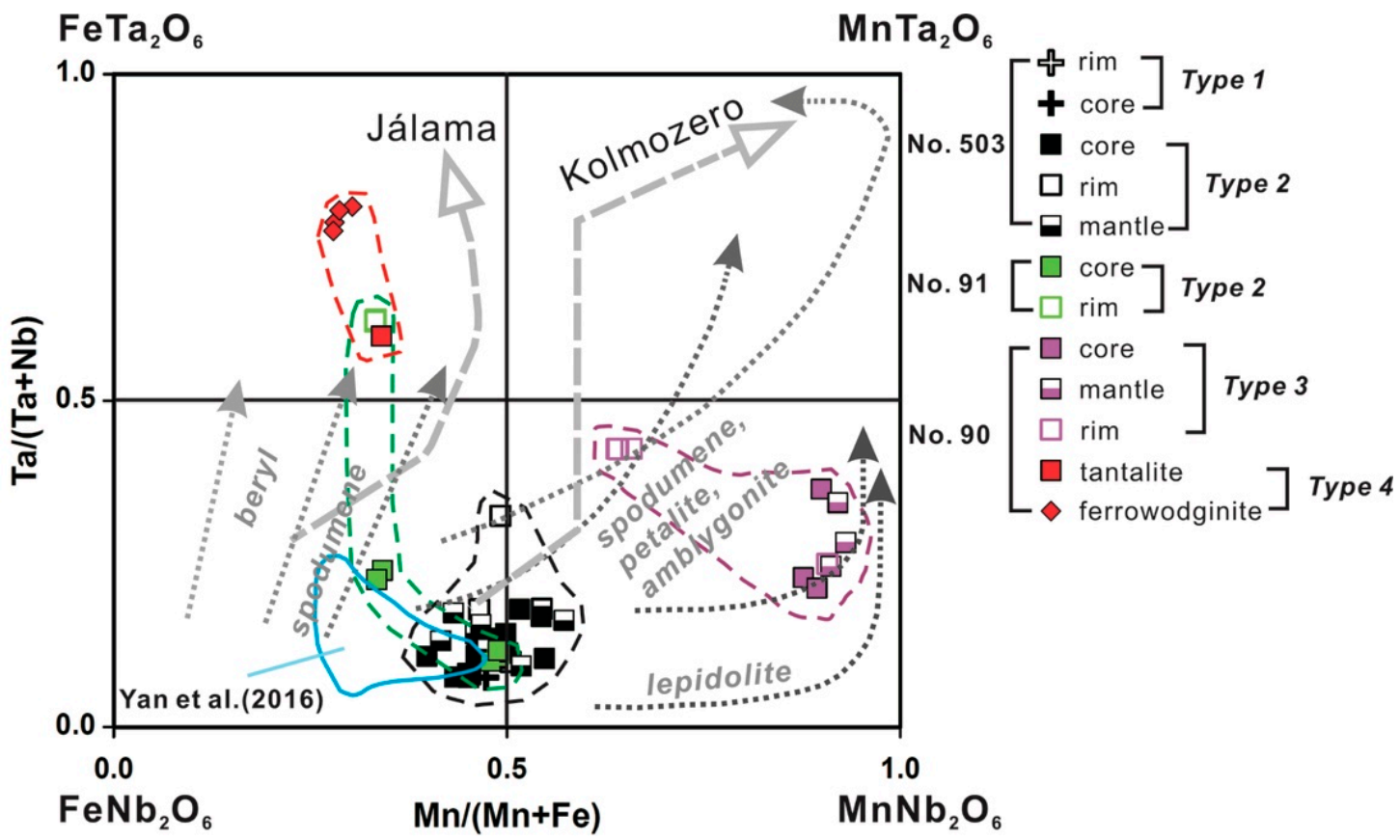

Figure 6. Columbite-Tantalite quadrilateral (after [45]) for CGM and ferrowodginite from No. 90, 91 and 503 pegmatites. Evolutionary trends of CGM compositions from Jálama and Kolmozero are generalized using the relevant data provided in [14] and [8], respectively. Generalized evolutionary trends of CGM compositions occurring in beryl- and complex- (spodumene, petalite, amblygonite and lepidolite) types of rare-element pegmatites are modified after [11,45]. The field circled by a blue line in the diagram represents the compositions of CGM in [21].

In No. 90 pegmatite, all types of CGM are present except Type 1. The composition of Type 2 CGM from No. 90 pegmatite is represented by the area circled with a blue solid line in Figure 6, showing that Type 2 CGM from No. 90 pegmatite are characterized by low $\mathrm{Mn} /(\mathrm{Mn}+\mathrm{Fe})$ and $\mathrm{Ta} /(\mathrm{Ta}+\mathrm{Nb})$ ratios. Types 3 and 4 CGM show distinctly different compositions from Type 2 CGM in terms of $\mathrm{Ta} /(\mathrm{Ta}+\mathrm{Nb})$ and $\mathrm{Mn} /(\mathrm{Mn}+\mathrm{Fe})$ ratios (Figure 6). The core and mantle of Type 3 CGM contain similar $\mathrm{FeOt}, \mathrm{MnO}, \mathrm{Nb}_{2} \mathrm{O}_{5}, \mathrm{Ta}_{2} \mathrm{O}_{5}$, and $\mathrm{WO}_{3}$ contents (Table 1). Also, the core and mantle show almost similar $\mathrm{Ta} /(\mathrm{Ta}+\mathrm{Nb})$ and $\mathrm{Mn} /(\mathrm{Mn}+\mathrm{Fe})$ ratios (Figure 6). Nevertheless, the rim of this type contains higher $\mathrm{FeOt}$ and $\mathrm{Ta}_{2} \mathrm{O}_{5}$ contents but lower $\mathrm{MnO}$ and $\mathrm{Nb}_{2} \mathrm{O}_{5}$ than the core and mantle (Table 1). Therefore, the rim shows higher $\mathrm{Ta} /(\mathrm{Ta}+\mathrm{Nb})$ ratios but lower $\mathrm{Mn} /(\mathrm{Mn}+\mathrm{Fe})$ ratios (Figure 6). $\mathrm{The} \mathrm{WO}_{3}$ contents are consistent from core to rim, varying between $0.23 \pm 0.01 \mathrm{wt}$. \% to $0.26 \pm 0.05 \mathrm{wt}$. \%. Type 4 CGM and its intergrown ferrowodginite are characterized by relatively high $\mathrm{Ta} /(\mathrm{Mn}+\mathrm{Fe})$ but low $\mathrm{Mn} /(\mathrm{Mn}+\mathrm{Fe})$, compared with other CGM types. Unlike Type 2 CGM from the other two pegmatites, Type 2 CGM from No. 91 pegmatite show decreasing $\mathrm{Mn} /(\mathrm{Mn}+\mathrm{Fe})$ ratio but increasing $\mathrm{Ta} /(\mathrm{Ta}+\mathrm{Nb})$ ratio, from core to rim (Figure 6). In addition, Sc shows negative correlation with $\mathrm{Nb}+\mathrm{Ta}$ but positive correlation with Ta in all types of CGMs (Figure 7). 

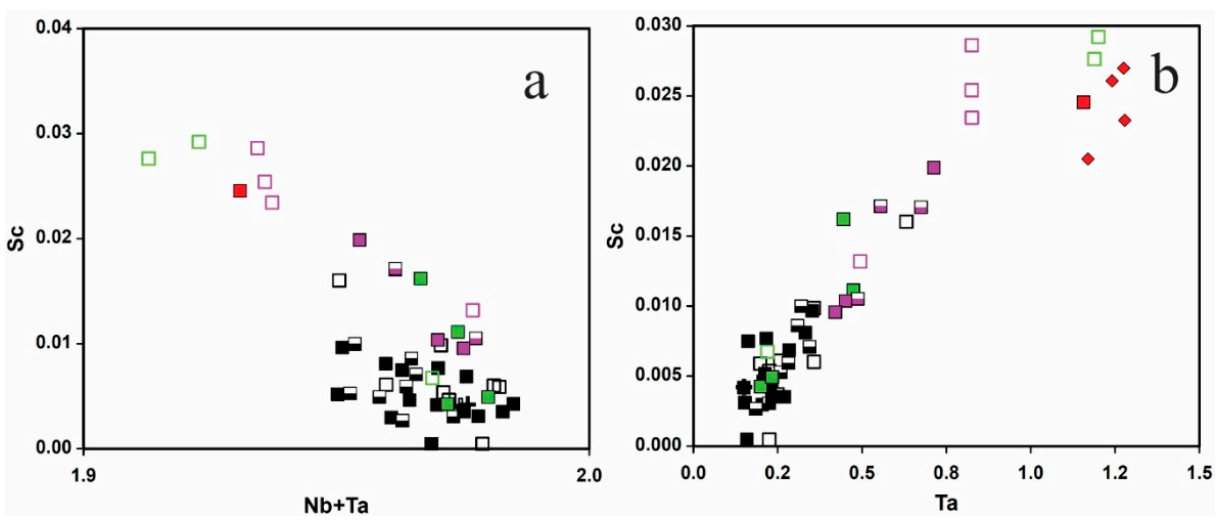

Figure 7. Binary plots for $\mathrm{Nb}$-Ta oxides based on EPMA data. (a,b) Sc (in a.p.f.u.) versus $\mathrm{Nb}+\mathrm{Ta}$ (in a.p.f.u.), and versus Ta (in a.p.f.u.) binary plots. Symbols are the same as in Figure 6.

\subsubsection{Cassiterite}

Cassiterite from No. 503 pegmatite generally shows increasing $\mathrm{SnO}_{2}$ content from core to rim, with the core containing the lowest average $\mathrm{SnO}_{2}$ content $(90.87 \pm 4.47$ wt. \%) (Table 2). The core contains relatively high FeOt $\left(0.85 \pm 0.68\right.$ wt. \%), $\mathrm{Nb}_{2} \mathrm{O}_{5}\left(2.13 \pm 1.75\right.$ wt. \%), and $\mathrm{Ta}_{2} \mathrm{O}_{5}(3.49 \pm 1.67$ wt. \%) contents compared to the mantle and rim. The $\mathrm{TiO}_{2}$ and $\mathrm{WO}_{3}$ of the cassiterite are below $0.25 \mathrm{wt}$. \%.

In No. 90 pegmatite, cassiterite shows no obvious variation of $\mathrm{SnO}_{2}$ content from core to rim but the contents of $\mathrm{FeOt}, \mathrm{Nb}_{2} \mathrm{O}_{5}$, and $\mathrm{Ta}_{2} \mathrm{O}_{5}$ are variable (Table 2). The core contains slightly higher $\mathrm{Ta}_{2} \mathrm{O}_{5}$ $\left(2.11 \pm 3.40\right.$ wt. \%) than the mantle and core that contain $0.69 \pm 0.70 \mathrm{wt} . \%$ and $0.47 \pm 0.28 \mathrm{wt} . \% \mathrm{Ta}_{2} \mathrm{O}_{5}$, respectively (Table 2). The FeOt $(0.45 \pm 0.71 \mathrm{wt}$. \%) of the core is also slightly higher than the mantle and rim. Both core and rim contain higher $\mathrm{Nb}_{2} \mathrm{O}_{5}$ content $(0.18 \pm 0.27$ wt. $\%$ and $0.28 \pm 0.19$ wt. \%, respectively) than the mantle containing. $28 \pm 0.19 \mathrm{wt} . \% \mathrm{Nb}_{2} \mathrm{O}_{5} . \mathrm{WO}_{3}$ content is low and most analyses show $\mathrm{WO}_{3}$ content below detection limit.

In No. 91 pegmatite, cassiterite is compositionally homogeneous and shows no large variation of $\mathrm{SnO}_{2}, \mathrm{FeOt}, \mathrm{Nb}_{2} \mathrm{O}_{5}$, and $\mathrm{Ta}_{2} \mathrm{O}_{5}$ contents from core to rim (Table 2). The $\mathrm{SnO}_{2}$ content of the core, mantle, and rim are $94.61 \pm 2.93$ wt. \%, $93.89 \pm 1.77$ wt. $\%$, and $94.31 \pm 1.05$ wt. $\%$, respectively.

Overall, $\mathrm{Nb}+\mathrm{Ta}$ shows negative correlation with $\mathrm{Sn}$ in cassiterite, whereas $\mathrm{Fe}+\mathrm{Mn}$ shows positive correlation with $\mathrm{Nb}+\mathrm{Ta}$ (Figure $8 \mathrm{a}, \mathrm{b}$ ). The correlations between $\mathrm{Nb}+\mathrm{Ta}$ and $\mathrm{Sn}$ and between $\mathrm{Fe}+\mathrm{Mn}$ and $\mathrm{Nb}+\mathrm{Ta}$ indicate negative correlation between $\mathrm{Fe}+\mathrm{Mn}$ and $\mathrm{Sn}$ (not shown in Figure 8). The Fe $+\mathrm{Mn}$ versus $\mathrm{Nb}+$ Ta binary plot shows that the data plot along the trend for magmatic cassiterite proposed in previous studies [13,46,47].
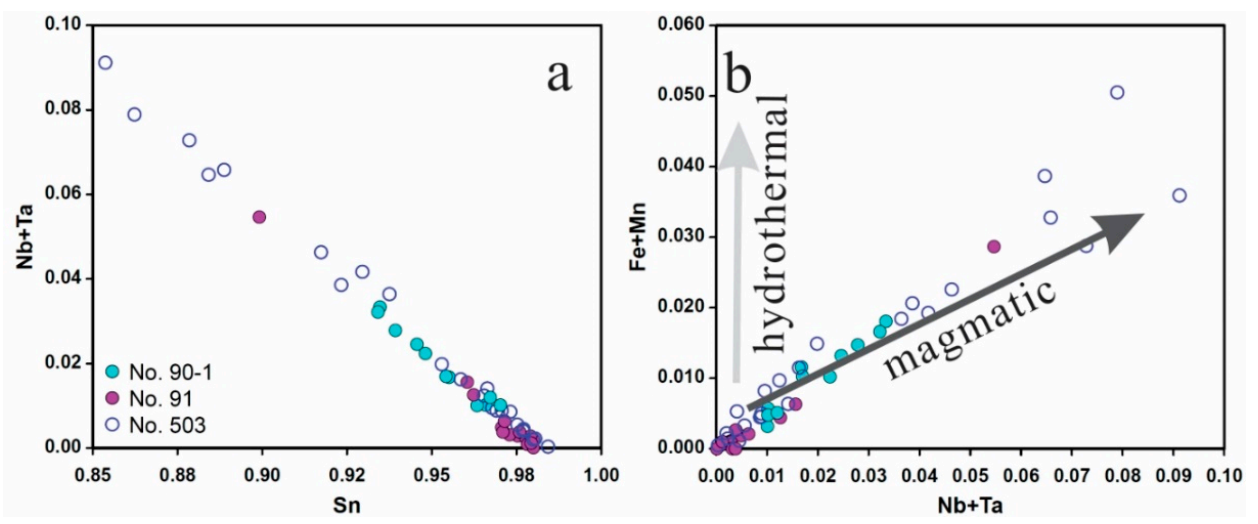

Figure 8. Binary plots for cassiterite based on EPMA data (in a.p.f.u.). (a) $\mathrm{Nb}+\mathrm{Ta}$ vs. Sn binary plot and (b) $\mathrm{Fe}+\mathrm{Mn}$ vs. $\mathrm{Nb}+\mathrm{Ta}$ binary plot. The hydrothermal and magmatic evolutionary paths of cassiterite compositions are cited from Breiter et al. [13]. 

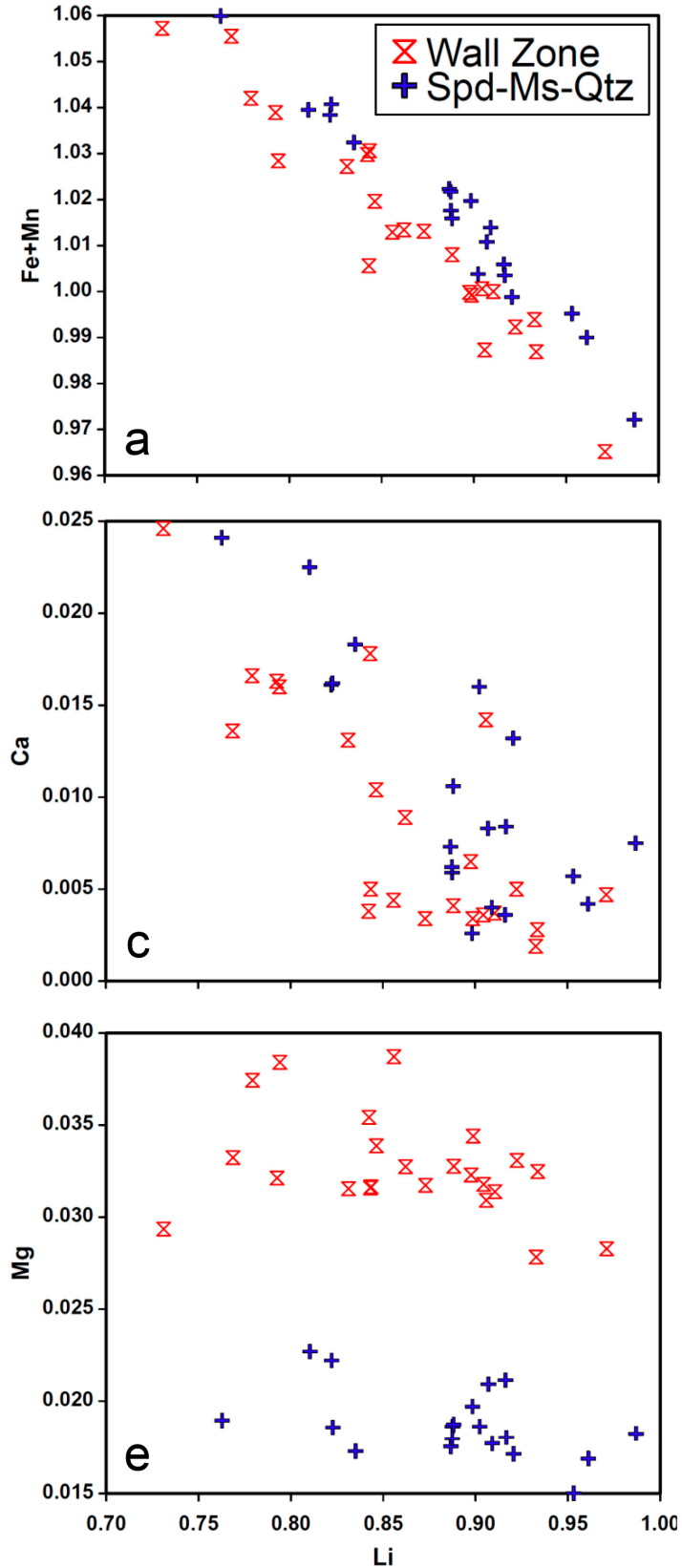
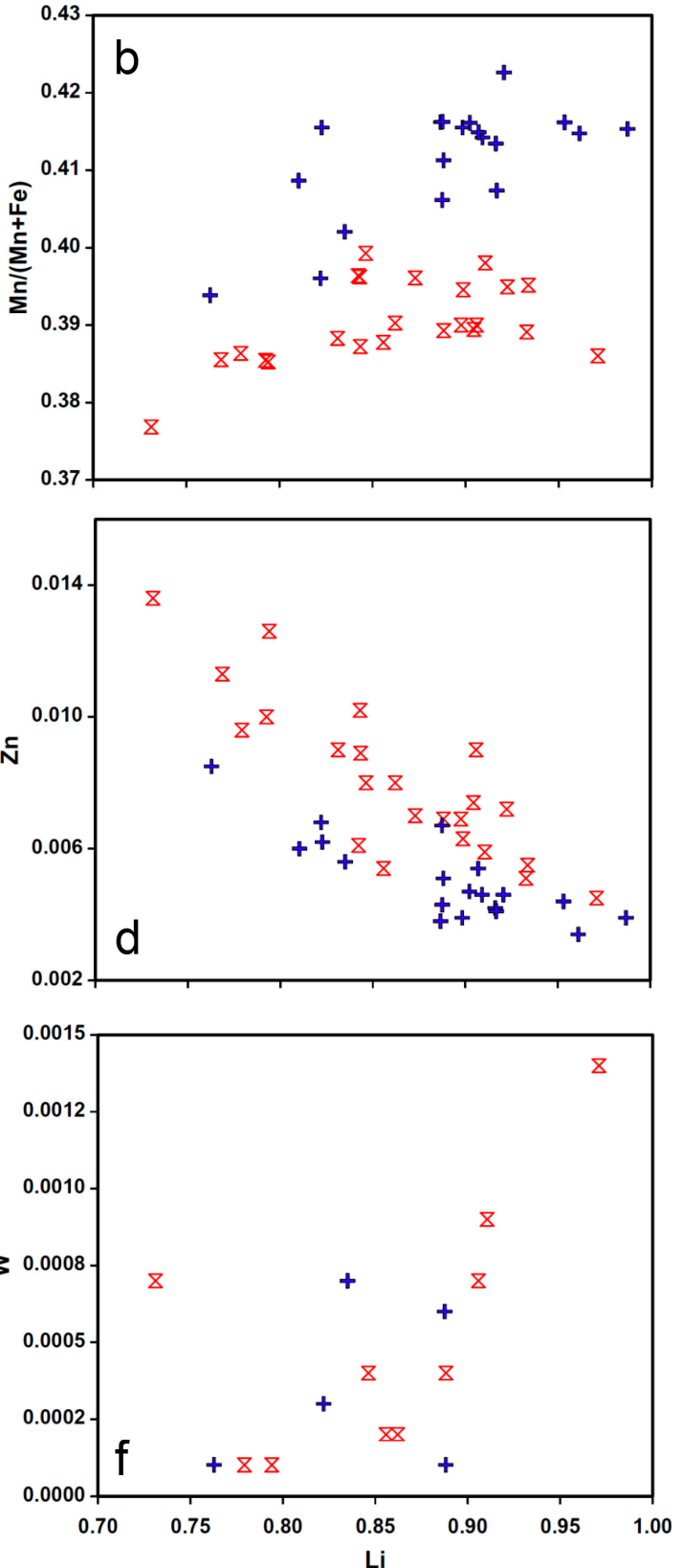

Figure 9. Binary plots of $\mathrm{Fe}+\mathrm{Mn}(\mathbf{a}), \mathrm{Mn} /(\mathrm{Mn}+\mathrm{Fe})(\mathbf{b}), \mathrm{Ca}(\mathbf{c}), \mathrm{Zn}(\mathbf{d}), \mathrm{Mg}(\mathbf{e})$, and $\mathrm{W}(\mathbf{f})$ versus $\mathrm{Li}$ for triphylite from the Wall Zone and spodumene-muscovite-quartz zone of No. 90 pegmatite based on EPMA data (in a.p.f.u.). Elemental concentrations are expressed in a.p.f.u. values.

\subsubsection{Triphylite}

The triphylite-lithiophilite series from the WZ and SMQZ of No. 90 pegmatite was analyzed for major elements using EPMA. The compositions of the triphylite-lithiophilite series from both zones are dominated by triphylite component (Table 3). Apart from $\mathrm{P}, \mathrm{Fe}, \mathrm{Mn}$, and $\mathrm{Li}$ that are major elements in triphylite, $\mathrm{Mg}, \mathrm{Ca}$, and $\mathrm{Zn}$ are present in minor amounts. In general, $\mathrm{Fe}+\mathrm{Mn}$ (in a.p.f.u.) negatively correlates with $\mathrm{Li}$ (in a.p.f.u.) (Figure 9a). According to [48], triphylite and sarcopside $\left((\mathrm{Fe}, \mathrm{Mn})^{2+}{ }_{1.5}\left(\mathrm{PO}_{4}\right)\right)$ can form solid solution at relatively high temperature. The negative correlation between $\mathrm{Fe}+\mathrm{Mn}$ and $\mathrm{Li}$ can be explained by a substitution mechanism $\mathrm{Li}^{+}+\mathrm{Li}^{+} \rightarrow(\mathrm{Fe}, \mathrm{Mn})^{2+}+\square$. The excess $\mathrm{Fe}+\mathrm{Mn}$ can also be explained by this substitution mechanism. The $\mathrm{Mn} /(\mathrm{Mn}+\mathrm{Fe})$ ratio increases with increasing $\mathrm{Li}$ and the triphylite from the $\mathrm{WZ}$ exhibits higher $\mathrm{Mn} /(\mathrm{Mn}+\mathrm{Fe})$ ratio than that from the SMQZ (Figure 9b). Calcium and Zn generally show negative correlation with $\mathrm{Li}$ 
(Figure 9c,d) whereas Mg no obvious correlation with Li content (Figure 9e). Tungsten exhibits positive correlation with Li (Figure 9f). Moreover, the triphylite from the WZ contains higher $\mathrm{Zn}$ and $\mathrm{Mg}$ content than that from the SMQZ (Figure 9d,e).

\subsection{LA-ICP-MS}

\subsubsection{CGM and Ferrowodginite}

Type 2 CGM from No. 503 pegmatite and Type 3 and 4 CGM from No. 90 pegmatite were analyzed for trace elements using LA-ICP-MS. The trace element concentrations of the ferrowodginite associated with Type 4 CGM were also determined. Type 1 CGM from No. 503 pegmatite and Type 2 CGM from No.90 and No. 91 pegmatites were not analyzed due to small grain size.

Type 2 CGM from No. 503 pegmatite contains 777-5716 ppm Ti, 0.5-6.6 ppm Sc, 199-2422 ppm $\mathrm{Zr}, 29-212 \mathrm{ppm} \mathrm{Hf}$, and 1157-3549 ppm W (Table 4). The Sn concentrations mostly range from 668 to 2813 ppm except one analysis showing Sn > 5000 ppm. The Li concentrations mostly vary between 20 and 112 ppm. The LILE (including Rb, Sr, Cs, and Ba), REE, and Y concentrations mostly range from below $1 \mathrm{ppm}$ to several tens $\mathrm{ppm}$. The $\mathrm{Na}, \mathrm{Al}$, and $\mathrm{Si}$ concentrations are highly variable. The extremely high concentrations of these three elements (e.g., analyses 503-4.7) which are returned from the same analysis likely indicate presence of microinclusions of Na-Al silicate minerals (possibly albite). In addition, the extremely high Na concentration (3951 ppm) of Analysis 503-4.9 may be related to presence of fluid inclusions that are commonly dominated by $\mathrm{NaCl}$ solution. The $\mathrm{U}$ and $\mathrm{Pb}$ concentrations mostly range between 110 and 733 ppm and between 18 and 63 ppm, respectively.

Type 3 CGM from No. 90 pegmatite contains 5.5-39.6 ppm Li, 1.8-19.5 ppm Sc, 261.6-863.2 ppm Ti, 36.6-212.5 ppm Zr, 6.9-30.2 ppm Hf, 147.1-675.5 ppm Sn, and 845.8-2358.0 ppm W (Table 4). The concentrations of LILE, $\mathrm{Y}$, and REE are low (Table 4). The U and Pb concentrations are 50.2-202.7 ppm and 7.0-42.2 ppm, respectively.

The Li, Sc, Ti, Zr, Hf, Sn, and W concentrations of Type 4 CGM from No. 90 pegmatite are 14.5 ppm, 88.4 ppm, 6380 ppm, 1267 ppm, 252 ppm, 18248 ppm, and 562.5 ppm, respectively (Table 4). The ferrowodginite intergrown with Type 4 CGM from the same pegmatite contains 63.6-76.4 ppm Li, 82.1-128.1 ppm Sc, 13,649-19,956 ppm Ti, 3556-3727 ppm Zr, 848-898 ppm Hf, and 553-635 ppm W. Similar to the CGM of types 2, 3, and 4, the ferrowodginite contains extremely low LILE, Y, and REE concentrations.

It is noticeable that Type 3 and 4 CGM and ferrowodginite from No. 90 pegmatite show distinctly different trace element chemistry from Type 2 CGM from No. 503 pegmatite in terms of Ti, Sc, Zr, Hf, $\mathrm{Sn}$, and $\mathrm{W}$ concentrations as well as $\mathrm{Nb} / \mathrm{Ta}$ ratios (Figure 10; Table 4). Among three types, Type 3 CGM contains the lowest $\mathrm{Ti}, \mathrm{Zr}, \mathrm{Hf}$, and $\mathrm{Sn}$ concentrations. Type $4 \mathrm{CGM}$ and ferrowodginite contains the highest Ti, Sc, and Sn concentrations but the lowest W concentration (Figure 10a,b,e,f). Moreover, Type 3 and 4 CGM and ferrowodginite from No. 90 pegmatite are characterized by relatively low $\mathrm{Nb} / \mathrm{Ta}$ ratios, compared to CGM from No. 503 pegmatite. The $\mathrm{Nb} / \mathrm{Ta}$ ratio of Type 3 CGM ranges from 1.00 to 1.69 while that of Type 4 CGM and ferrowodginite from 0.15 to 0.30 . The $\mathrm{Nb} / \mathrm{Ta}$ ratio of Type 2 CGM from No. 503 pegmatite varies from 2.72 to 4.43 (Table 4). 
Table 4. LA-ICP-MS analyses of CGM from the Dahongliutan albite-spodumene pegmatites.

\begin{tabular}{|c|c|c|c|c|c|c|c|c|c|c|c|c|c|c|c|}
\hline Pegmatite & No. 90 & No. 90 & No. 90 & No. 90 & No. 90 & No. 90 & No. 90 & No. 90 & No. 90 & No. 90 & No. 90 & No. 90 & No. 90 & No. 90 & No. 503 \\
\hline Analysis \# & $90-1.17$ & $90-1.24$ & $90-1.18$ & $90-1.19$ & $90-1.25$ & $90-1.20$ & $90-1.21$ & $90-1.22$ & $90-1.23$ & $90-1.26$ & D026.1 & D026.2 & D026.3 & D026.4 & $503-4.1$ \\
\hline Types & 3 & 3 & 3 & 3 & 3 & 3 & 3 & 3 & 3 & 3 & 4 & 4 & 4 & 4 & 2 \\
\hline $\begin{array}{l}\text { Comments } \\
\text { in ppm }\end{array}$ & clb1. c & clb3. c & clb1. m & clb1. m & clb3. m & clb1. $\mathrm{r}$ & clb2. $\mathrm{r}$ & clb2. $\mathrm{r}$ & clb2. $\mathrm{r}$ & clb3. $\mathrm{r}$ & Fwdn2. c & Fwdn1. r & Fwdn1. $\mathrm{r}$ & $\mathrm{ttl1}$ & clb7. c \\
\hline $\mathrm{Li}$ & 30.8 & 10.1 & 12.2 & 5.5 & 9.5 & 18.4 & 12.6 & 19.6 & 39.6 & 9.7 & 76.4 & 75.4 & 63.6 & 14.5 & 170.2 \\
\hline $\mathrm{Be}$ & b.d. & b.d. & b.d. & b.d. & b.d. & b.d. & b.d. & b.d. & b.d. & b.d. & 0.6 & 0.7 & 0.1 & 0.1 & 1.0 \\
\hline $\mathrm{Na}$ & b.d. & b.d. & b.d. & b.d. & b.d. & b.d. & b.d. & b.d. & b.d. & b.d. & b.d. & b.d. & 9.7 & b.d. & 70.9 \\
\hline $\mathrm{Mg}$ & 55.7 & 23.1 & 31.4 & 17.3 & 38.6 & 46.3 & 39.3 & 34.2 & 70.4 & 32.4 & 349.5 & 392.8 & 385.4 & 505.7 & 19.5 \\
\hline $\mathrm{Al}$ & 14 & 4 & 5 & b.d. & 5 & 7 & 6 & 6 & 10 & b.d. & 728 & 480 & 563 & 127 & 9495 \\
\hline $\mathrm{P}$ & b.d. & b.d. & b.d. & b.d. & b.d. & b.d. & b.d. & b.d. & b.d. & 110 & 81 & 59 & b.d. & b.d. & 74 \\
\hline $\mathrm{Ca}$ & b.d. & 153 & b.d. & b.d. & b.d. & b.d. & b.d. & b.d. & 501 & b.d. & b.d. & b.d. & b.d. & b.d. & b.d. \\
\hline Sc & 7.9 & 2.3 & 3.5 & 5.4 & 4.2 & 6.8 & 2.7 & 1.8 & 19.5 & 6.1 & 128.1 & 125.4 & 82.1 & 88.4 & 1.8 \\
\hline $\mathrm{Ti}$ & 547 & 262 & 311 & 375 & 361 & 511 & 340 & 326 & 863 & 433 & 19956 & 14455 & 13649 & 6380 & 2005 \\
\hline $\mathrm{V}$ & b.d. & b.d. & 0.15 & b.d. & b.d. & 0.08 & 0.11 & 0.17 & 0.80 & 0.35 & 50.31 & 40.94 & 32.77 & 15.30 & 0.09 \\
\hline $\mathrm{Mn}$ & 209,711 & 114,588 & 138,484 & 152,602 & 148,390 & 195,211 & 139,000 & 141,416 & 212,970 & 198,165 & 30,772 & 29,879 & 31,479 & 41,052 & 95,515 \\
\hline $\mathrm{Fe}$ & 20,397 & 7261 & 11,569 & 6390 & 9880 & 18,616 & 13,707 & 17,922 & 27,640 & 11,270 & 70,410 & 69,081 & 68,962 & 77,241 & 85,527 \\
\hline Ga & 0.5 & 0.2 & 0.2 & 0.3 & b.d. & 0.2 & 0.1 & 0.3 & 0.4 & 0.4 & 11.9 & 9.4 & 9.4 & 4.6 & 11.0 \\
\hline $\mathrm{Rb}$ & 0.2 & b.d. & b.d. & 0.0 & 0.0 & b.d. & 0.2 & b.d. & b.d. & b.d. & 0.2 & b.d. & 1.4 & b.d. & 280.9 \\
\hline $\mathrm{Sr}$ & 0.0 & 0.0 & b.d. & 0.1 & 0.0 & b.d. & 0.3 & b.d. & b.d. & b.d. & 0.3 & b.d. & 0.0 & 0.1 & b.d. \\
\hline $\mathrm{Nb}$ & 501,129 & 256,503 & 319,236 & 301,711 & 349,605 & 457,895 & 312,615 & 359,817 & 516,526 & 428,286 & 78,627 & 70,719 & 78,657 & 140,593 & 459,525 \\
\hline Sn & 425 & 153 & 191 & 201 & 192 & 269 & 147 & 212 & 675 & 258 & 104055 & 83628 & 81062 & 18248 & 1308 \\
\hline $\mathrm{Sb}$ & b.d. & b.d. & b.d. & b.d. & b.d. & b.d. & 0.4 & 0.2 & b.d. & b.d. & 0.4 & 0.4 & b.d. & 0.1 & 0.2 \\
\hline Cs & 1.5 & b.d. & 0.2 & 0.2 & 0.3 & 0.4 & 0.5 & 0.3 & 0.6 & 0.3 & 0.3 & 0.1 & 0.5 & 0.2 & 11.7 \\
\hline $\mathrm{Ba}$ & b.d. & b.d. & b.d. & b.d. & 0.1 & 0.1 & b.d. & b.d. & b.d. & b.d. & 1.4 & 0.4 & 0.7 & 0.1 & 0.3 \\
\hline $\mathrm{La}$ & b.d. & b.d. & b.d. & b.d. & b.d. & b.d. & b.d. & 0.01 & b.d. & b.d. & 0.01 & 0.01 & 0.02 & b.d. & b.d. \\
\hline $\mathrm{Ce}$ & 0.01 & b.d. & 0.01 & 0.01 & b.d. & b.d. & b.d. & 0.01 & b.d. & 0.04 & 0.01 & b.d. & b.d. & b.d. & 0.03 \\
\hline $\operatorname{Pr}$ & b.d. & b.d. & b.d. & 0.01 & b.d. & b.d. & b.d. & b.d. & 0.01 & 0.03 & 0.01 & 0.02 & 0.02 & 0.02 & b.d. \\
\hline $\mathrm{Nd}$ & b.d. & 0.07 & b.d. & b.d. & 0.04 & b.d. & b.d. & 0.03 & b.d. & b.d. & b.d. & b.d. & b.d. & 0.05 & b.d. \\
\hline $\mathrm{Sm}$ & 0.05 & b.d. & 0.12 & 0.13 & 0.05 & b.d. & b.d. & b.d. & b.d. & 0.10 & 0.03 & b.d. & b.d. & b.d. & b.d. \\
\hline $\mathrm{Eu}$ & 0.01 & b.d. & 0.01 & b.d. & b.d. & 0.02 & b.d. & b.d. & 0.07 & 0.04 & b.d. & b.d. & b.d. & 0.03 & b.d. \\
\hline $\mathrm{Gd}$ & 0.05 & b.d. & b.d. & 0.17 & b.d. & b.d. & 0.14 & b.d. & 0.18 & b.d. & 0.05 & b.d. & 0.03 & 0.06 & b.d. \\
\hline $\mathrm{Tb}$ & 0.03 & 0.01 & 0.01 & 0.02 & 0.01 & 0.02 & 0.02 & 0.01 & 0.03 & 0.04 & b.d. & 0.03 & b.d. & b.d. & b.d. \\
\hline Dy & 0.15 & 0.05 & 0.19 & 0.15 & 0.10 & 0.04 & b.d. & b.d. & 0.21 & 0.09 & 0.13 & 0.04 & 0.03 & 0.03 & 0.09 \\
\hline Ho & 0.08 & 0.03 & b.d. & 0.02 & 0.02 & b.d. & 0.04 & 0.01 & 0.22 & 0.04 & 0.05 & b.d. & 0.02 & 0.00 & 0.05 \\
\hline
\end{tabular}


Table 4. Cont

\begin{tabular}{|c|c|c|c|c|c|c|c|c|c|c|c|c|c|c|c|}
\hline Pegmatite & No. 90 & No. 90 & No. 90 & No. 90 & No. 90 & No. 90 & No. 90 & No. 90 & No. 90 & No. 90 & No. 90 & No. 90 & No. 90 & No. 90 & No. 503 \\
\hline $\mathrm{Er}$ & 0.21 & 0.10 & 0.21 & 0.19 & b.d. & 0.30 & b.d. & 0.08 & 0.38 & 0.35 & 0.16 & 0.12 & 0.01 & 0.08 & 0.10 \\
\hline $\mathrm{Tm}$ & 0.09 & 0.03 & 0.01 & 0.08 & 0.02 & 0.10 & 0.06 & 0.01 & 0.09 & 0.03 & 0.07 & 0.08 & 0.02 & 0.03 & 0.01 \\
\hline $\mathrm{Yb}$ & 0.85 & 0.20 & 0.21 & 0.26 & 0.51 & 0.92 & 0.55 & b.d. & 0.65 & b.d. & 0.59 & 0.98 & b.d. & 0.25 & 0.35 \\
\hline $\mathrm{Lu}$ & 0.11 & 0.02 & 0.06 & 0.12 & 0.07 & 0.13 & 0.06 & 0.01 & 0.22 & 0.10 & 0.19 & 0.17 & 0.06 & 0.11 & 0.07 \\
\hline $\mathrm{Hf}$ & 15.5 & 7.6 & 8.3 & 8.5 & 7.7 & 15.8 & 6.9 & 8.5 & 30.2 & 10.2 & 879.8 & 847.8 & 898.4 & 251.8 & 93.2 \\
\hline $\mathrm{Ta}$ & 318,036 & 200,654 & 231,005 & 301,075 & 255,958 & 352,612 & 230,227 & 212,414 & 361,285 & 360,368 & $488,731.9$ & $472,115.2$ & $487,675.4$ & $466,054.9$ & 128,658 \\
\hline $\mathrm{W}$ & 1791.5 & 845.8 & 1037.9 & 974.9 & 1125.2 & 1652.8 & 1190.9 & 1400.2 & 2358.0 & 1368.2 & 552.9 & 558.8 & 634.7 & 562.5 & 2310.5 \\
\hline $\mathrm{Tl}$ & 0.1 & 0.1 & 0.1 & 0.1 & 0.0 & b.d. & b.d. & 0.1 & b.d. & b.d. & 0.15 & 0.08 & 0.18 & b.d. & 3.3 \\
\hline $\mathrm{Pb}$ & 26.4 & 7.0 & 10.4 & 12.4 & 9.5 & 15.7 & 7.3 & 9.0 & 42.2 & 12.2 & 24.3 & 16.6 & 23.3 & 53.9 & 42.3 \\
\hline Th & 0.7 & 0.2 & 0.3 & 0.4 & 0.2 & 0.7 & 0.4 & 0.3 & 1.0 & 0.4 & 0.7 & 0.2 & 0.4 & 1.3 & 1.4 \\
\hline $\mathrm{U}$ & 105.2 & 50.2 & 59.3 & 73.7 & 59.0 & 108.7 & 54.3 & 55.2 & 202.7 & 78.6 & 139.0 & 126.8 & 154.4 & 333.3 & 307.7 \\
\hline$\Sigma$ REE & 1.66 & 0.51 & 0.83 & 1.15 & 0.81 & 1.53 & 0.88 & 0.17 & 2.05 & 0.86 & 1.29 & 1.47 & 0.20 & 0.65 & 0.70 \\
\hline $\mathrm{Nb} / \mathrm{Ta}$ & 1.58 & 1.28 & 1.38 & 1.00 & 1.37 & 1.30 & 1.36 & 1.69 & 1.43 & 1.19 & 0.16 & 0.15 & 0.16 & 0.30 & 3.57 \\
\hline $\mathrm{Zr} / \mathrm{Hf}$ & 6.43 & 4.81 & 6.23 & 6.08 & 5.07 & 5.76 & 7.29 & 7.21 & 7.04 & 4.14 & 4.11 & 4.19 & 4.15 & 5.03 & 8.65 \\
\hline $\mathrm{Sn} / \mathrm{W}$ & 0.24 & 0.18 & 0.18 & 0.21 & 0.17 & 0.16 & 0.12 & 0.15 & 0.29 & 0.19 & 188.20 & 149.65 & 127.72 & 32.44 & 0.57 \\
\hline Pegmatite & No. 503 & No. 503 & No. 503 & No. 503 & No. 503 & No. 503 & No. 503 & No. 503 & No. 503 & No. 503 & No. 503 & No. 503 & No. 503 & No. 503 & No. 503 \\
\hline Analysis \# & $503-4.2$ & $503-4.3$ & $503-4.4$ & $503-4.5$ & $503-4.6$ & $503-4.7$ & $503-4.8$ & D023-1 & $503-4.8$ & $503-4.9$ & 503-4.10 & 503-4.11 & D023.1 & D023.2 & D023.3 \\
\hline Types & 2 & 2 & 2 & 2 & 2 & 2 & 2 & 2 & 2 & 2 & 2 & 2 & 2 & 2 & 2 \\
\hline $\mathrm{Li}$ & 112.4 & 36.6 & 61.5 & 95.5 & 78.0 & 6.0 & 49.0 & 79.8 & 6.8 & b.d. & 19.1 & 22.3 & 62.6 & 9.8 & 92.7 \\
\hline $\mathrm{Be}$ & b.d. & 0.3 & b.d. & 0.3 & 6.4 & 0.4 & 116.4 & b.d. & b.d. & 2.3 & 0.3 & 0.2 & 0.5 & b.d. & 0.3 \\
\hline $\mathrm{Na}$ & 883.5 & 31.1 & b.d. & 12.0 & 48.9 & 5515.3 & 46.8 & 13.7 & 347.7 & 3951.2 & 608.7 & 17.2 & 29.9 & b.d. & 30.7 \\
\hline $\mathrm{Mg}$ & 22.6 & 13.2 & 5.9 & 16.8 & 11.9 & 11.2 & 8.3 & 19.9 & 9.2 & 31.1 & 10.6 & 21.8 & 819.1 & 12.4 & 14.3 \\
\hline $\mathrm{Al}$ & 2804 & 317 & 25 & 626 & 1746 & 7718 & 401 & 34 & 658 & b.d. & 1435 & 336 & 44 & 33 & 44 \\
\hline $\mathrm{Si}$ & 8512 & b.d. & 1214 & 1908 & 11,161 & 24,224 & 3010 & b.d. & 3931 & b.d. & 5444 & 1661 & b.d. & 906 & 769 \\
\hline $\mathrm{P}$ & 122 & 257 & 40 & 843 & 202 & b.d. & b.d. & b.d. & b.d. & b.d. & 57 & b.d. & b.d. & b.d. & b.d. \\
\hline $\mathrm{Ca}$ & 666 & 485 & 150 & 1340 & b.d. & b.d. & b.d. & b.d. & 250 & b.d. & b.d. & b.d. & b.d. & 119 & b.d. \\
\hline Sc & 2.4 & 0.9 & 0.5 & 1.4 & 2.0 & 2.4 & 0.7 & 1.3 & 1.8 & b.d. & 0.9 & 0.8 & 3.5 & 6.6 & 0.5 \\
\hline $\mathrm{Ti}$ & 1218 & 1168 & 777 & 1404 & 931 & 1377 & 1168 & 2172 & 1741 & 1443 & 1153 & 1304 & 4292 & 5716 & 1249 \\
\hline V & 0.41 & b.d. & 0.12 & 0.40 & b.d. & 0.02 & b.d. & b.d. & b.d. & b.d. & b.d. & b.d. & 0.06 & 0.05 & b.d. \\
\hline Mn & 104,709 & 84,983 & 83,320 & 85,186 & 88,741 & 80,000 & 92,045 & 76,141 & 92,070 & 88,322 & 79,636 & 83,900 & 69,900 & 80,644 & 74,618 \\
\hline $\mathrm{Fe}$ & 72,601 & 70,831 & 83,251 & 77,891 & 112,605 & 82,811 & 74,902 & 85,222 & 84,915 & 81,037 & 72,604 & 81,980 & 94,834 & 75,496 & 80,977 \\
\hline $\mathrm{Ga}$ & 2.2 & 0.5 & 0.2 & 1.2 & 6.5 & 4.9 & 0.6 & 0.7 & 0.8 & 24.8 & 1.1 & 0.7 & 1.1 & 1.6 & 1.0 \\
\hline $\mathrm{Rb}$ & 2.5 & 1.6 & 0.7 & 6.0 & 81.1 & 0.1 & 0.6 & 0.4 & 0.1 & b.d. & 0.2 & 0.0 & 0.3 & b.d. & 0.8 \\
\hline Sr & 8.3 & 20.4 & 0.0 & 5.9 & b.d. & 0.4 & b.d. & 1.7 & 0.6 & b.d. & 0.2 & 0.7 & 1.5 & b.d. & 0.5 \\
\hline
\end{tabular}


Table 4. Cont.

\begin{tabular}{|c|c|c|c|c|c|c|c|c|c|c|c|c|c|c|c|}
\hline Pegmatite & No. 503 & No. 503 & No. 503 & No. 503 & No. 503 & No. 503 & No. 503 & No. 503 & No. 503 & No. 503 & No. 503 & No. 503 & No. 503 & No. 503 & No. 503 \\
\hline $\mathrm{Y}$ & 1.85 & 1.32 & 4.57 & 0.96 & 1.86 & 0.88 & 1.69 & 6.6 & 1.01 & 0.72 & 1.08 & 1.21 & 11.7 & 2.2 & 5.2 \\
\hline $\mathrm{Zr}$ & 752.5 & 473.2 & 1084.8 & 280.6 & 227.7 & 239.8 & 755.7 & 1679.1 & 531.5 & 198.5 & 304.5 & 388.3 & 2422.1 & 1769.3 & 1302.5 \\
\hline $\mathrm{Nb}$ & 450,878 & 421,721 & 434,038 & 447,760 & 410,809 & 439,337 & 446,369 & 394,689 & 446,593 & 465,600 & 421,735 & 445,481 & 438,009 & 388,776 & 409,879 \\
\hline Sn & 984 & 992 & 1128 & 668 & 1047 & 760 & 897 & 1695 & 994 & 59377 & 741 & 718 & 2813 & 2037 & 1395 \\
\hline $\mathrm{Sb}$ & 0.5 & 1.4 & b.d. & 1.7 & 1.1 & b.d. & 0.6 & 1.2 & 0.2 & 2.1 & b.d. & 0.4 & 1.1 & 0.4 & 0.8 \\
\hline Cs & 2.3 & 4.3 & 1.1 & 0.9 & 3.4 & 0.6 & 21.9 & 1.1 & 0.4 & 25.5 & 0.4 & 0.7 & 1.0 & 0.4 & 1.2 \\
\hline $\mathrm{Ba}$ & b.d. & 2.9 & b.d. & 1.0 & b.d. & 0.2 & b.d. & 2.4 & 0.1 & 8.3 & 0.1 & 0.8 & 8.0 & 0.8 & 3.1 \\
\hline $\mathrm{La}$ & b.d. & b.d. & b.d. & 0.02 & b.d. & 0.02 & b.d. & 0.01 & b.d. & 0.10 & b.d. & b.d. & b.d. & b.d. & b.d. \\
\hline $\mathrm{Ce}$ & b.d. & b.d. & b.d. & 0.03 & b.d. & 0.34 & b.d. & b.d. & b.d. & 0.04 & 0.02 & b.d. & b.d. & b.d. & b.d. \\
\hline $\mathrm{Nd}$ & 1.02 & b.d. & 0.07 & b.d. & b.d. & b.d. & b.d. & b.d. & b.d. & 0.43 & b.d. & b.d. & b.d. & b.d. & b.d. \\
\hline Sm & b.d. & b.d. & b.d. & b.d. & b.d. & b.d. & b.d. & b.d. & 0.13 & b.d. & b.d. & b.d. & 0.32 & b.d. & b.d. \\
\hline $\mathrm{Eu}$ & b.d. & b.d. & b.d. & b.d. & b.d. & b.d. & 0.01 & 0.03 & b.d. & b.d. & 0.02 & b.d. & b.d. & b.d. & b.d. \\
\hline $\mathrm{Gd}$ & 0.55 & b.d. & b.d. & b.d. & b.d. & 0.10 & b.d. & 0.64 & 0.06 & b.d. & 0.09 & b.d. & 0.20 & b.d. & b.d. \\
\hline $\mathrm{Tb}$ & b.d. & 0.02 & 0.10 & 0.03 & b.d. & b.d. & 0.02 & 0.14 & 0.01 & b.d. & 0.01 & b.d. & 0.30 & b.d. & 0.09 \\
\hline Dy & 0.98 & 0.18 & 0.66 & 0.18 & b.d. & b.d. & 0.30 & 1.69 & b.d. & b.d. & b.d. & 0.26 & 2.50 & 0.43 & 0.57 \\
\hline Но & 0.40 & 0.02 & 0.16 & 0.02 & b.d. & b.d. & 0.08 & 0.25 & b.d. & b.d. & 0.07 & b.d. & 0.37 & b.d. & 0.13 \\
\hline Er & b.d. & 0.10 & 0.47 & 0.05 & b.d. & 0.14 & 0.15 & 0.72 & 0.13 & b.d. & 0.15 & 0.22 & 0.94 & b.d. & 0.25 \\
\hline $\mathrm{Tm}$ & 0.07 & 0.02 & 0.10 & 0.05 & b.d. & 0.01 & 0.05 & 0.15 & 0.02 & 0.03 & 0.01 & 0.08 & 0.25 & 0.09 & 0.04 \\
\hline $\mathrm{Yb}$ & b.d. & 0.27 & 1.42 & 0.38 & 2.20 & 0.46 & 0.49 & 1.46 & 0.31 & b.d. & 0.28 & 0.28 & 1.87 & 0.08 & 0.70 \\
\hline $\mathrm{Ta}$ & 119,276 & 118,941 & 126,589 & 104,152 & 175,362 & 127,149 & 132,439 & 143,376 & 115,463 & 119,983 & 95,265 & 102,763 & 110,822 & 142,906 & 141,028 \\
\hline W & 3549.0 & 2355.9 & 1655.1 & 1405.2 & 1849.4 & 1157.0 & 2586.0 & 1944.7 & 2018.9 & 1699.4 & 1498.9 & 2477.3 & 2786.0 & 2437.9 & 2380.8 \\
\hline $\mathrm{Tl}$ & b.d. & 0.3 & 0.1 & b.d. & b.d. & 0.1 & b.d. & 0.32 & 0.1 & 3.7 & 0.0 & 0.1 & 0.05 & b.d. & 0.56 \\
\hline $\mathrm{Pb}$ & 41.6 & 51.0 & 93.4 & 29.4 & 18.3 & 19.0 & 39.5 & 111.7 & 33.5 & 26.3 & 25.2 & 34.8 & 185.1 & 50.7 & 63.2 \\
\hline $\mathrm{Bi}$ & 0.18 & 0.35 & 0.22 & 3.91 & 0.60 & 0.09 & 0.22 & 0.10 & 0.12 & 0.39 & 0.11 & 0.44 & 0.15 & 0.12 & 0.22 \\
\hline Th & 1.8 & 1.4 & 7.7 & 1.2 & b.d. & 0.3 & 1.0 & 1.8 & 0.9 & 1.0 & 0.5 & 0.8 & 4.4 & 1.1 & 1.1 \\
\hline $\mathrm{U}$ & 325.1 & 286.1 & 699.9 & 163.0 & 77.9 & 117.9 & 313.6 & 733.3 & 213.9 & 110.4 & 147.3 & 193.2 & 1355.7 & 469.9 & 464.2 \\
\hline$\Sigma$ REE & 3.12 & 0.65 & 3.23 & 0.86 & 2.20 & 1.11 & 1.16 & 5.26 & 0.70 & 0.64 & 0.67 & 0.89 & 6.90 & 0.60 & 1.83 \\
\hline $\mathrm{Nb} / \mathrm{Ta}$ & 3.78 & 3.55 & 3.43 & 4.30 & 2.34 & 3.46 & 3.37 & 2.75 & 3.87 & 3.88 & 4.43 & 4.34 & 3.95 & 2.72 & 2.91 \\
\hline $\mathrm{Zr} / \mathrm{Hf}$ & 10.57 & 9.39 & 9.94 & 9.03 & 7.05 & 8.26 & 9.18 & 10.34 & 8.38 & 5.91 & 9.26 & 9.55 & 11.43 & 12.10 & 10.68 \\
\hline $\mathrm{Sn} / \mathrm{W}$ & 0.28 & 0.42 & 0.68 & 0.48 & 0.57 & 0.66 & 0.35 & 0.87 & 0.49 & 34.94 & 0.49 & 0.29 & 1.01 & 0.84 & 0.59 \\
\hline
\end{tabular}

Note: $\mathrm{clb} —$ columbite, fwdn—ferrowodgenite, $\mathrm{ttl}$-tantalite; $\mathrm{b} . \mathrm{d} .=$ below detection limit; $\mathrm{r}=$ rim, $\mathrm{m}=$ mantle, and $\mathrm{c}=$ core. 
Table 5. LA-ICP-MS analyses of cassiterite from the Dahongliutan albite-spodumene pegmatites.

\begin{tabular}{|c|c|c|c|c|c|c|c|c|c|c|c|c|c|c|}
\hline Pegmatite & No. 90 & No. 90 & No. 90 & No. 90 & No. 90 & No. 90 & No. 90 & No. 90 & No. 90 & No. 90 & No. 90 & No. 90 & No. 91 & No. 91 \\
\hline Analysis \# & $90-1.6$ & $90-1.7$ & $90-1.8$ & $90-1.9$ & $90-1.10$ & $90-1.12$ & $90-1.13$ & $90-1.14$ & $90-1.15$ & D026-13.4 & 2D026-13.4- & -3D026-13.4-4 & $90-1-3$ & $90-1-3$ \\
\hline Sample ID & $90-1$ & $90-1$ & $90-1$ & $90-1$ & 90-1 & $90-1$ & $90-1$ & $90-1$ & 90-1 & 26-13.4 & 26-13.4 & 26-13.4 & $1-3.11$ & $1-3.11-1$ \\
\hline $\begin{array}{l}\text { Comments } \\
\text { in ppm }\end{array}$ & cst1, c & cst1, m & cst $1, \mathrm{~m}$ & cst1, r & cst2, c & cst $2, \mathrm{~m}$ & cst $2, \mathrm{~m}$ & cst $2, \mathrm{~m}$ & cst2, r & cst1, c & cst $1, \mathrm{~m}$ & cst1, r & cst1, c & cst1, m \\
\hline $\mathrm{Li}$ & 0.6 & b.d & b.d & b.d & b.d & b.d. & b.d. & b.d. & b.d. & 1.0 & b.d & 0.5 & 6.9 & 5.7 \\
\hline $\mathrm{Be}$ & b.d & b.d & b.d & b.d & b.d & b.d. & b.d. & b.d. & b.d. & b.d & 0.1 & b.d & 3.4 & 17.3 \\
\hline $\mathrm{Na}$ & b.d & b.d & b.d & b.d & b.d & b.d. & b.d. & b.d. & b.d. & b.d & b.d & b.d & 7.3 & 8.7 \\
\hline $\mathrm{Mg}$ & 0.5 & 0.7 & 2.7 & 0.5 & 0.6 & 0.6 & 0.6 & 0.5 & b.d. & 0.7 & 0.8 & 0.6 & 2.0 & 1.2 \\
\hline $\mathrm{Al}$ & 34 & 45 & 33 & 32 & 45 & 49 & 40 & 35 & 54 & 214 & 136 & 130 & 632 & 679 \\
\hline $\mathrm{Si}$ & 1544 & 1608 & b.d & 1074 & 1417 & 1321 & 1618 & 1228 & b.d & b.d & 1289 & 960 & 1024 & 1169 \\
\hline $\mathrm{P}$ & b.d & b.d & b.d & 67 & b.d & b.d & b.d & b.d & b.d & b.d & b.d & b.d & 37 & b.d. \\
\hline $\mathrm{Ca}$ & b.d & b.d & b.d & b.d & b.d & b.d & 165 & b.d & b.d & b.d & b.d & b.d & b.d. & b.d. \\
\hline $\mathrm{Sc}$ & 4.3 & 4.0 & 4.2 & 4.0 & 3.5 & 3.3 & 2.7 & 2.4 & 1.9 & 1.0 & 1.2 & b.d. & 0.5 & 0.5 \\
\hline $\mathrm{Ti}$ & 932 & 785 & 889 & 886 & 614 & 656 & 599 & 565 & 411 & 447 & 1373 & 616 & 643 & 466 \\
\hline $\mathrm{V}$ & 10.9 & 10.7 & 9.9 & 9.6 & 4.9 & 5.0 & 4.3 & 3.2 & 2.5 & 0.1 & b.d. & b.d. & 0.11 & 0.04 \\
\hline $\mathrm{Mn}$ & 79 & 75 & 55 & 53 & 54 & 59 & 52 & 36 & 92 & 455 & 104 & 226 & 311 & 275 \\
\hline $\mathrm{Fe}$ & 327 & 290 & 231 & 212 & 244 & 245 & 231 & 152 & 468 & 6795 & 2676 & 3352 & 7943 & 8872 \\
\hline $\mathrm{Ga}$ & 1.9 & 1.8 & 1.1 & 1.9 & 2.0 & 1.8 & 1.8 & 1.5 & 2.2 & 7.7 & 4.1 & 4.2 & 19.4 & 21.7 \\
\hline $\mathrm{Rb}$ & b.d. & b.d. & 0.0 & b.d. & 0.0 & 0.0 & b.d. & 0.0 & 0.0 & b.d. & 0.0 & 0.0 & 0.1 & b.d. \\
\hline $\mathrm{Sr}$ & b.d. & b.d. & 0.1 & 0.0 & b.d. & b.d. & 0.0 & 0.0 & 0.0 & b.d. & b.d. & b.d. & 0.0 & 0.0 \\
\hline $\mathrm{Y}$ & b.d. & b.d. & b.d. & b.d. & 0.0 & b.d. & 0.0 & b.d. & b.d. & b.d. & b.d. & b.d. & 0.0 & 0.0 \\
\hline $\mathrm{Zr}$ & 189 & 208 & 179 & 188 & 199 & 203 & 192 & 184 & 270 & 468 & 431 & 308 & 873 & 742 \\
\hline $\mathrm{Nb}$ & 185 & 241 & 144 & 150 & 218 & 232 & 212 & 156 & 514 & 2673 & 3753 & 1989 & 20,256 & 15,988 \\
\hline Sn & 761,261 & 754,062 & 752,376 & 752,605 & 769,209 & 763,388 & 759,308 & 764,073 & 759,363 & 745,263 & 753,487 & 753,487 & 761,568 & 761,568 \\
\hline $\mathrm{Sb}$ & 1.0 & 0.4 & 0.6 & 0.8 & b.d. & 0.5 & 0.7 & 1.7 & 0.5 & 0.7 & 0.8 & b.d. & 0.8 & 0.6 \\
\hline Cs & 0.4 & 0.2 & 0.2 & 0.2 & 0.2 & 0.2 & 0.3 & 0.4 & 0.2 & 0.2 & 0.3 & 0.2 & 1.1 & 0.7 \\
\hline $\mathrm{Ba}$ & 4.2 & 3.4 & 3.4 & 4.2 & 4.9 & 4.3 & 3.5 & 4.2 & 4.2 & 4.2 & 4.5 & 4.4 & 6.4 & 7.9 \\
\hline $\mathrm{La}$ & 0.09 & 0.08 & 0.08 & 0.12 & 0.05 & 0.11 & 0.07 & 0.10 & 0.08 & 0.08 & 0.08 & 0.05 & 0.16 & 0.14 \\
\hline $\mathrm{Ce}$ & 0.00 & 0.02 & 0.01 & 0.05 & 0.02 & 0.02 & 0.03 & 0.02 & 0.01 & b.d. & 0.03 & 0.02 & 0.04 & 0.02 \\
\hline $\operatorname{Pr}$ & 0.05 & b.d. & 0.06 & 0.07 & 0.08 & 0.09 & 0.05 & 0.09 & 0.09 & 0.09 & 0.07 & 0.06 & b.d. & 0.13 \\
\hline $\mathrm{Nd}$ & b.d. & b.d. & 0.02 & 0.04 & 0.02 & b.d. & b.d. & 0.04 & 0.02 & 0.04 & b.d. & b.d. & b.d. & b.d. \\
\hline $\mathrm{Sm}$ & b.d. & b.d. & b.d. & b.d. & 0.02 & b.d. & b.d. & 0.04 & b.d. & b.d. & b.d. & b.d. & b.d. & b.d. \\
\hline $\mathrm{Eu}$ & b.d. & 0.01 & b.d. & 0.01 & b.d. & 0.01 & b.d. & b.d. & b.d. & b.d. & b.d. & b.d. & b.d. & b.d. \\
\hline $\mathrm{Gd}$ & 0.18 & 0.12 & 0.09 & 0.16 & 0.14 & b.d. & 0.10 & 0.27 & 0.21 & 0.25 & 0.29 & 0.20 & 0.07 & 0.15 \\
\hline $\mathrm{Tb}$ & 0.02 & 0.01 & 0.03 & 0.01 & 0.01 & b.d. & 0.04 & 0.03 & 0.02 & 0.01 & 0.05 & 0.01 & 0.03 & 0.02 \\
\hline Dy & b.d. & 0.03 & b.d. & b.d. & 0.02 & b.d. & b.d. & 0.01 & 0.01 & 0.02 & b.d. & 0.04 & b.d. & 0.04 \\
\hline Ho & b.d. & b.d. & b.d. & b.d. & b.d. & 0.01 & b.d. & 0.01 & b.d. & b.d. & b.d. & b.d. & b.d. & 0.00 \\
\hline $\mathrm{Er}$ & b.d. & b.d. & 0.02 & b.d. & b.d. & b.d. & 0.01 & b.d. & b.d. & b.d. & b.d. & b.d. & b.d. & b.d. \\
\hline
\end{tabular}


Table 5. Cont.

\begin{tabular}{|c|c|c|c|c|c|c|c|c|c|c|c|c|c|c|}
\hline Pegmatite & No. 90 & No. 90 & No. 90 & No. 90 & No. 90 & No. 90 & No. 90 & No. 90 & No. 90 & No. 90 & No. 90 & No. 90 & No. 91 & No. 91 \\
\hline $\mathrm{Tm}$ & b.d. & b.d. & 0.01 & 0.01 & b.d. & b.d. & b.d. & 0.01 & b.d. & b.d. & b.d. & b.d. & b.d. & b.d. \\
\hline $\mathrm{Yb}$ & b.d. & b.d. & b.d. & 0.01 & b.d. & b.d. & b.d. & b.d. & b.d. & b.d. & b.d. & b.d. & b.d. & b.d. \\
\hline $\mathrm{Lu}$ & 0.01 & b.d. & b.d. & b.d. & b.d. & b.d. & b.d. & 0.00 & 0.00 & 0.00 & b.d. & b.d. & b.d. & 0.00 \\
\hline $\mathrm{Hf}$ & 71 & 92 & 68 & 72 & 118 & 120 & 117 & 110 & 120 & 344 & 168 & 217 & 182 & 175 \\
\hline $\mathrm{Ta}$ & 3811 & 3420 & 2642 & 2821 & 2755 & 2874 & 2613 & 2018 & 4359 & 42,261 & 13,835 & 21,336 & 16,646 & 29,071 \\
\hline W & 0.6 & 0.5 & 4.2 & 0.2 & 0.2 & 0.3 & 0.3 & 0.6 & 0.5 & 4.3 & 4.1 & 2.4 & 269.5 & 380.1 \\
\hline $\mathrm{Tl}$ & b.d. & 0.0 & 0.1 & b.d. & 0.1 & b.d. & 0.0 & 0.0 & b.d. & 0.02 & b.d. & 0.07 & b.d. & 0.1 \\
\hline $\mathrm{Pb}$ & b.d. & 0.1 & 0.3 & 0.1 & b.d. & 0.0 & 0.0 & b.d. & 0.1 & 0.5 & b.d. & 0.2 & 2.5 & 2.3 \\
\hline $\mathrm{Bi}$ & 0.01 & 0.00 & 0.02 & b.d. & 0.01 & 0.01 & 0.01 & b.d. & 0.02 & b.d. & 0.01 & 0.01 & b.d. & 0.04 \\
\hline Th & b.d. & b.d. & 0.0 & 0.0 & b.d. & b.d. & 0.0 & b.d. & 0.0 & 0.0 & b.d. & b.d. & 0.01 & b.d. \\
\hline $\mathrm{U}$ & 0.1 & b.d. & 0.1 & 0.1 & 0.0 & b.d. & 0.1 & 0.0 & 0.1 & 1.6 & 1.7 & 1.3 & 17.0 & 20.8 \\
\hline $\mathrm{Mn} /(\mathrm{Mn}+\mathrm{Fe})$ & 0.2 & 0.2 & 0.2 & 0.2 & 0.2 & 0.2 & 0.2 & 0.2 & 0.2 & 0.1 & 0.0 & 0.1 & 0.0 & 0.0 \\
\hline$\Sigma$ REE & 0.36 & 0.27 & 0.32 & 0.49 & 0.37 & 0.24 & 0.29 & 0.62 & 0.43 & 0.51 & 0.52 & 0.39 & 0.30 & 0.50 \\
\hline $\mathrm{Nb} / \mathrm{Ta}$ & 0.05 & 0.07 & 0.05 & 0.05 & 0.08 & 0.08 & 0.08 & 0.08 & 0.12 & 0.06 & 0.27 & 0.09 & 1.22 & 0.55 \\
\hline $\mathrm{Zr} / \mathrm{Hf}$ & 2.67 & 2.27 & 2.63 & 2.59 & 1.69 & 1.69 & 1.64 & 1.67 & 2.25 & 1.36 & 2.57 & 1.42 & 4.79 & 4.24 \\
\hline $\mathrm{Sn} / \mathrm{W}$ & $1,239,414$ & $1,575,795$ & 180,947 & $3,091,815$ & $3,327,149$ & $2,548,274$ & $2,216,522$ & $1,341,883$ & $1,562,796$ & 171,594 & 181,988 & 315,745 & 2826 & 2004 \\
\hline Pegmatite & No. 91 & No. 91 & No. 91 & No. 91 & No. 91 & No. 91 & No. 91 & No. 503 & No. 503 & No. 503 & No. 503 & No. 503 & No. 503 & No. 503 \\
\hline Analysis \# & $91-1-3$ & $91-1-3$ & $91-1-3$ & $91-1-3$ & $91-1-3$ & $91-1-3$ & $91-1-3$ & D023-1 & D023-1 & D023-1 & D023-1 & D023-1 & D023-1 & D023-1 \\
\hline Sample ID & $1-3.12$ & $1-3.13$ & $1-3.14$ & $1-3.2$ & $1-3.3$ & $1-3.4$ & $1-3.5$ & $23-1.1$ & $23-1.2$ & $23-1.3$ & $23-1.4$ & $23-1.14$ & $23-1.15$ & $23-1.16$ \\
\hline $\begin{array}{l}\text { Comments } \\
\text { in ppm }\end{array}$ & $\operatorname{cst} 1, \mathrm{~m}$ & $\operatorname{cst} 1, \mathrm{~m}$ & $\operatorname{cst} 1, \mathrm{r}$ & cst2, c & cst2, m & $\mathrm{cst} 2, \mathrm{~m}$ & cst2, r & cst1, c & cst $1, \mathrm{~m}$ & $\operatorname{cst} 1, \mathrm{~m}$ & $\operatorname{cst} 1, \mathrm{r}$ & $\operatorname{cst} 3, \mathrm{c}$ & $\operatorname{cst} 3, \mathrm{~m}$ & cst $3, \mathrm{r}$ \\
\hline $\mathrm{Li}$ & 6.7 & 5.8 & & 6.7 & 2.8 & 13.6 & 4.9 & 16.1 & 5.7 & 15.8 & 10.0 & 3.4 & 6.2 & 2.0 \\
\hline $\mathrm{Be}$ & 157.0 & 29.6 & 0.1 & 47.6 & 12.2 & 11.5 & 53.3 & 0.6 & 0.7 & 31.6 & 2.0 & 4.4 & 39.8 & 0.3 \\
\hline $\mathrm{Na}$ & b.d. & b.d. & b.d. & b.d. & b.d. & 9.9 & b.d. & b.d. & b.d. & b.d. & 7.8 & b.d. & b.d. & b.d. \\
\hline $\mathrm{Mg}$ & 0.8 & 1.3 & 1.8 & b.d. & 1.0 & 1.7 & 1.2 & 1.6 & 0.9 & 0.9 & b.d. & b.d. & 0.8 & 1.9 \\
\hline $\mathrm{Al}$ & 1981 & 762 & 127 & 745 & 546 & 382 & 804 & 157 & 148 & 645 & 185 & 63 & 801 & 13 \\
\hline $\mathrm{Si}$ & 1111 & b.d. & b.d. & b.d. & 1166 & b.d. & b.d. & 529 & 1099 & b.d. & 1329 & 1696 & 1339 & 1028 \\
\hline $\mathrm{P}$ & 36 & b.d. & b.d. & b.d. & b.d. & 162 & b.d. & b.d. & b.d. & b.d. & 60 & b.d. & b.d. & b.d. \\
\hline $\mathrm{Ca}$ & b.d. & b.d. & b.d. & b.d. & b.d. & b.d. & b.d. & b.d. & b.d. & b.d. & b.d. & b.d. & b.d. & b.d. \\
\hline Sc & 0.5 & b.d. & b.d. & b.d. & 0.3 & b.d. & b.d. & 1.2 & b.d. & 1.3 & b.d. & 0.3 & 1.1 & b.d. \\
\hline $\mathrm{Ti}$ & 730 & 458 & 302 & 217 & 309 & 335 & 367 & 1293 & 990 & 2366 & 1362 & 934 & 2297 & 474 \\
\hline $\mathrm{V}$ & b.d. & b.d. & 0.29 & b.d. & b.d. & b.d. & b.d. & b.d. & 0.06 & b.d. & 0.06 & b.d. & b.d. & 0.07 \\
\hline Mn & 98 & 287 & 92 & 87 & 163 & 410 & 163 & 935 & 165 & 195 & 104 & 12 & 85 & 7 \\
\hline $\mathrm{Fe}$ & 5269 & 9130 & 2912 & 3026 & 5548 & 5569 & 5361 & 7062 & 2319 & 4462 & 2235 & 323 & 3538 & 145 \\
\hline $\mathrm{Ga}$ & 61.3 & 23.1 & 3.8 & 17.5 & 13.8 & 13.2 & 20.0 & 8.5 & 9.2 & 25.5 & 5.8 & 2.3 & 30.1 & 0.8 \\
\hline $\mathrm{Rb}$ & b.d. & b.d. & 1.1 & 0.5 & b.d. & 5.3 & 0.0 & 0.3 & 0.3 & 0.2 & 0.2 & 0.3 & 0.2 & 0.2 \\
\hline
\end{tabular}


Table 5. Cont.

\begin{tabular}{|c|c|c|c|c|c|c|c|c|c|c|c|c|c|c|}
\hline Pegmatite & No. 91 & No. 91 & No. 91 & No. 91 & No. 91 & No. 91 & No. 91 & No. 503 & No. 503 & No. 503 & No. 503 & No. 503 & No. 503 & No. 503 \\
\hline $\mathrm{Sr}$ & b.d. & 0.0 & 0.0 & b.d. & b.d. & b.d. & 0.0 & b.d. & 0.1 & 0.0 & 0.2 & 0.1 & b.d. & 0.0 \\
\hline Y & 0.0 & 0.0 & b.d. & 0.0 & b.d. & b.d. & 0.0 & b.d. & 0.0 & 0.0 & b.d. & b.d. & b.d. & b.d. \\
\hline $\mathrm{Zr}$ & 697 & 731 & 625 & 329 & 532 & 933 & 530 & 1202 & 1062 & 1513 & 834 & 611 & 951 & 104 \\
\hline $\mathrm{Nb}$ & 8295 & 14,688 & 2816 & 5451 & 10,411 & 6352 & 8632 & 19,455 & 6480 & 10061 & 5933 & 696 & 8229 & 237 \\
\hline Sn & 734,984 & 749,470 & 751,447 & 728,927 & 721,901 & 751,777 & 729,463 & 690,512 & 744,200 & 760,568 & 753,762 & 763,246 & 746,547 & 746,831 \\
\hline $\mathrm{Sb}$ & 0.7 & 0.8 & 0.6 & 0.9 & 0.9 & 0.9 & 0.7 & 3.3 & 2.2 & 2.0 & 2.7 & 3.0 & 1.9 & 2.3 \\
\hline $\mathrm{Cs}$ & 0.4 & 0.4 & 0.7 & 2.1 & 0.7 & 48.1 & 0.4 & 1.2 & 0.9 & 0.8 & 1.1 & 1.0 & 0.8 & 0.9 \\
\hline $\mathrm{Ba}$ & 8.2 & 6.2 & 7.8 & 5.7 & 7.3 & 6.3 & 6.7 & 8.3 & 7.3 & 7.1 & 7.7 & 8.0 & 6.3 & 6.7 \\
\hline $\mathrm{La}$ & 0.10 & 0.12 & 0.11 & 0.11 & 0.12 & 0.14 & b.d. & 0.11 & 0.15 & 0.12 & 0.13 & 0.13 & 0.13 & 0.11 \\
\hline $\mathrm{Ce}$ & 0.03 & 0.02 & 0.03 & 0.05 & 0.01 & 0.04 & 0.02 & 0.05 & 0.03 & 0.03 & 0.03 & 0.03 & 0.02 & 0.03 \\
\hline $\operatorname{Pr}$ & 0.16 & 0.15 & 0.09 & 0.10 & 0.14 & b.d. & 0.14 & 0.11 & 0.13 & 0.16 & 0.14 & 0.10 & 0.16 & 0.15 \\
\hline $\mathrm{Nd}$ & b.d. & 0.02 & b.d. & b.d. & b.d. & b.d. & 0.01 & 0.07 & b.d. & b.d. & b.d. & b.d. & b.d. & b.d. \\
\hline $\mathrm{Sm}$ & b.d. & 0.04 & b.d. & 0.03 & b.d. & b.d. & b.d. & b.d. & b.d. & b.d. & b.d. & b.d. & b.d. & b.d. \\
\hline $\mathrm{Eu}$ & b.d. & 0.01 & 0.01 & 0.03 & b.d. & b.d. & b.d. & b.d. & b.d. & b.d. & b.d. & b.d. & b.d. & 0.01 \\
\hline $\mathrm{Gd}$ & 0.22 & 0.23 & 0.15 & 0.09 & b.d. & b.d. & 0.31 & b.d. & 0.18 & 0.12 & b.d. & 0.17 & 0.28 & b.d. \\
\hline $\mathrm{Tb}$ & 0.02 & 0.04 & 0.03 & 0.04 & 0.03 & 0.04 & 0.02 & 0.04 & 0.02 & 0.03 & 0.06 & 0.02 & 0.01 & 0.02 \\
\hline Dy & b.d. & b.d. & b.d. & b.d. & b.d. & b.d. & 0.03 & b.d. & 0.03 & b.d. & b.d. & b.d. & 0.02 & 0.01 \\
\hline Ho & b.d. & b.d. & 0.01 & b.d. & b.d. & 0.01 & b.d. & 0.01 & b.d. & 0.00 & 0.01 & 0.00 & 0.01 & b.d. \\
\hline Er & b.d. & b.d. & b.d. & b.d. & 0.01 & b.d. & b.d. & 0.03 & b.d. & b.d. & 0.03 & b.d. & b.d. & 0.02 \\
\hline $\mathrm{Tm}$ & b.d. & 0.01 & 0.00 & b.d. & b.d. & b.d. & b.d. & b.d. & b.d. & b.d. & b.d. & b.d. & 0.00 & b.d. \\
\hline $\mathrm{Yb}$ & b.d. & 0.01 & b.d. & 0.04 & b.d. & b.d. & 0.02 & b.d. & 0.02 & b.d. & b.d. & b.d. & 0.04 & b.d. \\
\hline $\mathrm{Lu}$ & b.d. & b.d. & 0.01 & b.d. & 0.00 & b.d. & b.d. & 0.01 & b.d. & 0.00 & 0.01 & b.d. & 0.00 & b.d. \\
\hline Hf & 148 & 184 & 211 & 70 & 131 & 267 & 132 & 228 & 195 & 255 & 181 & 123 & 143 & 49 \\
\hline $\mathrm{Ta}$ & 12,901 & 33,120 & 16,747 & 9871 & 18,964 & 26,138 & 19,714 & 11,490 & 4145 & 6530 & 3443 & 885 & 3211 & 567 \\
\hline W & 80.5 & 276.8 & 2.8 & 270.9 & 282.1 & 200.0 & 167.3 & 115 & 74 & 48 & 421 & 6 & 48 & 4 \\
\hline $\mathrm{Tl}$ & 0.1 & b.d. & 0.0 & b.d. & b.d. & b.d. & 0.0 & b.d. & 0.23 & b.d. & b.d. & 0.05 & b.d. & b.d. \\
\hline $\mathrm{Pb}$ & 2.8 & 2.6 & 0.6 & 2.0 & 1.9 & 1.3 & 1.7 & 2.4 & 1.8 & 1.9 & 1.9 & b.d. & 1.9 & 0.6 \\
\hline $\mathrm{Bi}$ & 0.01 & 0.01 & b.d. & 0.02 & b.d. & b.d. & b.d. & 0.08 & 0.05 & 0.05 & b.d. & b.d. & 0.01 & b.d. \\
\hline Th & 0.00 & b.d. & b.d. & b.d. & b.d. & 0.03 & 0.00 & 0.0 & 0.0 & b.d. & 0.0 & 0.0 & 0.0 & 0.0 \\
\hline $\mathrm{U}$ & 26.9 & 21.1 & 1.1 & 17.7 & 14.1 & 10.0 & 12.2 & 13.0 & 4.7 & 10.0 & 8.4 & 0.5 & 7.6 & 0.3 \\
\hline $\mathrm{Mn} /(\mathrm{Mn}+\mathrm{Fe})$ & 0.0 & 0.0 & 0.0 & 0.0 & 0.0 & 0.1 & 0.0 & 0.1 & 0.1 & 0.0 & 0.0 & 0.0 & 0.0 & 0.0 \\
\hline$\Sigma$ REE & 0.53 & 0.63 & 0.44 & 0.49 & 0.32 & 0.23 & 0.57 & 0.42 & 0.55 & 0.46 & 0.41 & 0.46 & 0.68 & 0.34 \\
\hline $\mathrm{Nb} / \mathrm{Ta}$ & 0.64 & 0.44 & 0.17 & 0.55 & 0.55 & 0.24 & 0.44 & 1.69 & 1.56 & 1.54 & 1.72 & 0.79 & 2.56 & 0.42 \\
\hline $\mathrm{Zr} / \mathrm{Hf}$ & 4.71 & 3.97 & 2.96 & 4.68 & 4.07 & 3.49 & 4.00 & 5.28 & 5.44 & 5.94 & 4.60 & 4.96 & 6.63 & 2.12 \\
\hline $\mathrm{Sn} / \mathrm{W}$ & 9128 & 2708 & 267,663 & 2691 & 2559 & 3760 & 4360 & 5988 & 10,091 & 16,001 & 1790 & 117,983 & 15,412 & 196,541 \\
\hline
\end{tabular}


Table 5. Cont.

\begin{tabular}{|c|c|c|c|c|c|c|c|c|c|c|c|c|c|}
\hline Pegmatite & No. 503 & No. 503 & No. 503 & No. 503 & No. 503 & No. 503 & No. 503 & No. 503 & No. 503 & No. 503 & No. 503 & No. 503 & No. 503 \\
\hline Analysis \# & D023-1 & D023-1 & D023-1 & D023-1 & D023-1 & D023-1 & D023-1 & 503-4 & 503-4 & 503-4 & 503-4 & $503-4$ & 503-4 \\
\hline Sample ID & $23-1.20$ & $23-1.21$ & $23-1.22$ & $23-1.23$ & $23-1.24$ & $23-1.25$ & $23-1.26$ & 503-4.12 & $503-4.13$ & 503-4.14 & 503-4.17 & 503-4.18 & 503-4.19 \\
\hline $\begin{array}{l}\text { Comments } \\
\text { in ppm }\end{array}$ & cst2, c & cst2, m & cst2, m & cst $2, \mathrm{~m}$ & $\operatorname{cst} 4, \mathrm{c}$ & $\operatorname{cst} 4, \mathrm{~m}$ & cst $4, \mathrm{~m}$ & cst1, r & cst1, r & cst1, r & cst2, r & cst3, r & cst3, r \\
\hline $\mathrm{Li}$ & 5.2 & 6.1 & 7.2 & 12.4 & 17.5 & 7.4 & 6.5 & 23.4 & 26.3 & b.d. & 0.4 & 5.1 & 25.3 \\
\hline $\mathrm{Be}$ & 1.6 & b.d. & 49.6 & 1.1 & 13.7 & 0.2 & b.d. & b.d. & b.d. & b.d. & b.d. & 0.3 & 0.7 \\
\hline $\mathrm{Na}$ & b.d. & b.d. & 8.9 & 9.9 & 5.5 & b.d. & b.d. & b.d. & b.d. & 7.9 & b.d. & 33.8 & 25.3 \\
\hline $\mathrm{Mg}$ & 2.4 & 0.7 & 2.1 & 3.4 & 0.7 & 0.9 & 0.5 & b.d. & b.d. & 0.3 & b.d. & 0.8 & 19.4 \\
\hline $\mathrm{Al}$ & 306 & 272 & 549 & 376 & 362 & 136 & 113 & 1102 & 1326 & 109 & 226 & 112 & 672 \\
\hline $\mathrm{Si}$ & b.d. & b.d. & b.d. & 1936 & 1109 & 1721 & 1493 & 958 & b.d. & 1026 & b.d. & 1904 & 1454 \\
\hline $\mathrm{P}$ & b.d. & b.d. & b.d. & b.d. & 40 & b.d. & b.d. & b.d. & b.d. & b.d. & b.d. & 79 & 307 \\
\hline $\mathrm{Ca}$ & b.d. & b.d. & b.d. & b.d. & b.d. & b.d. & b.d. & b.d. & b.d. & b.d. & b.d. & 299 & 909 \\
\hline Sc & 1.3 & 1.3 & 1.5 & 0.6 & 0.5 & 0.5 & b.d. & 1.0 & 1.9 & 0.9 & 0.8 & 0.6 & 0.4 \\
\hline $\mathrm{Ti}$ & 1603 & 1210 & 3255 & 951 & 1135 & 744 & 628 & 206 & 256 & 722 & 664 & 313 & 367 \\
\hline $\mathrm{V}$ & b.d. & b.d. & b.d. & b.d. & 0.05 & b.d. & 0.02 & b.d. & 0 & 0 & 0 & b.d. & 1 \\
\hline $\mathrm{Mn}$ & 266 & 150 & 1569 & 320 & 827 & 144 & 96 & 5313 & 7258 & 195 & 283 & 24 & 537 \\
\hline $\mathrm{Fe}$ & 8221 & 5021 & 6820 & 3144 & 3786 & 2190 & 1816 & 4602 & 8276 & 3530 & 5469 & 536 & 3287 \\
\hline $\mathrm{Ga}$ & 11.3 & 11.8 & 20.5 & 9.0 & 12.5 & 5.4 & 5.1 & 43.1 & 57.6 & 4.6 & 9.6 & 1.4 & 5.2 \\
\hline $\mathrm{Rb}$ & 0.1 & 0.3 & 0.2 & 7.8 & 0.5 & 0.0 & 0.4 & 0.1 & b.d. & 0.0 & b.d. & 0.0 & 0.9 \\
\hline $\mathrm{Sr}$ & 0.1 & b.d. & b.d. & 0.2 & 0.1 & b.d. & 0.0 & b.d. & 0.0 & 0.0 & b.d. & 1.1 & 19.4 \\
\hline $\mathrm{Y}$ & 0.0 & b.d. & 0.0 & b.d. & 0.0 & 0.0 & 0.0 & 0.02 & 0.05 & 0.01 & 0.02 & 0.01 & b.d. \\
\hline $\mathrm{Zr}$ & 1262 & 911 & 1739 & 667 & 675 & 448 & 417 & 3674 & 4903 & 1052 & 1101 & 308 & 418 \\
\hline $\mathrm{Nb}$ & 21,988 & 14,473 & 19,321 & 11,493 & 11,591 & 7808 & 7147 & 20,751 & 28,119 & 5830 & 10,313 & 776 & 5169 \\
\hline Sn & 727,509 & 740,671 & 723,547 & 751,360 & 756,220 & 741,483 & 751,525 & 675,011 & 667,252 & 727,903 & 753,203 & 764,309 & 678,705 \\
\hline $\mathrm{Sb}$ & 1.3 & 2.9 & 1.9 & 4.2 & 3.1 & 1.5 & 3.9 & 0.4 & 0.5 & 0.6 & 0.5 & 2.3 & 8.8 \\
\hline Cs & 0.8 & 0.9 & 0.7 & 4.3 & 1.2 & 0.7 & 1.0 & 0.3 & 0.2 & 0.3 & 0.3 & 0.4 & 1.0 \\
\hline $\mathrm{Ba}$ & 7.3 & 7.9 & 7.0 & 6.4 & 6.5 & 6.6 & 7.9 & 6.0 & 4.7 & 4.6 & 5.9 & 4.6 & 5.3 \\
\hline $\mathrm{La}$ & 0.14 & 0.13 & 0.17 & 0.15 & 0.10 & 0.17 & 0.08 & 0.12 & 0.09 & 0.11 & 0.14 & 0.09 & 0.07 \\
\hline $\mathrm{Ce}$ & 0.03 & 0.02 & 0.02 & 0.05 & 0.02 & b.d. & 0.03 & 0.04 & 0.03 & 0.04 & b.d. & 0.01 & 0.02 \\
\hline $\operatorname{Pr}$ & 0.14 & 0.13 & b.d. & 0.14 & 0.17 & 0.17 & 0.10 & b.d. & 0.11 & 0.11 & 0.06 & 0.08 & 0.03 \\
\hline $\mathrm{Nd}$ & 0.03 & 0.09 & b.d. & 0.06 & 0.05 & b.d. & b.d. & b.d. & b.d. & 0.07 & b.d. & 0.02 & 0.03 \\
\hline $\mathrm{Sm}$ & b.d. & b.d. & b.d. & b.d. & 0.06 & b.d. & b.d. & b.d. & b.d. & b.d. & b.d. & b.d. & b.d. \\
\hline $\mathrm{Eu}$ & b.d. & 0.01 & 0.01 & b.d. & b.d. & b.d. & 0.01 & b.d. & b.d. & b.d. & b.d. & b.d. & b.d. \\
\hline $\mathrm{Gd}$ & 0.26 & 0.25 & 0.29 & 0.27 & 0.45 & 0.16 & 0.31 & 0.66 & 0.24 & 0.05 & b.d. & 0.29 & 0.32 \\
\hline $\mathrm{Tb}$ & 0.02 & 0.03 & 0.05 & 0.02 & b.d. & b.d. & 0.04 & 0.02 & 0.03 & b.d. & 0.03 & 0.02 & 0.02 \\
\hline Dy & 0.04 & 0.01 & 0.03 & b.d. & b.d. & 0.03 & b.d. & b.d. & b.d. & b.d. & 0.06 & b.d. & 0.04 \\
\hline Ho & b.d. & 0.00 & b.d. & 0.00 & b.d. & 0.02 & 0.02 & b.d. & 0.01 & 0.01 & 0.01 & 0.00 & b.d. \\
\hline $\mathrm{Er}$ & b.d. & b.d. & b.d. & b.d. & 0.01 & 0.05 & 0.01 & b.d. & b.d. & b.d. & 0.01 & b.d. & b.d. \\
\hline $\mathrm{Tm}$ & 0.01 & b.d. & b.d. & b.d. & 0.01 & b.d. & 0.01 & b.d. & 0.00 & 0.00 & b.d. & 0.01 & 0.00 \\
\hline
\end{tabular}


Table 5. Cont.

\begin{tabular}{|c|c|c|c|c|c|c|c|c|c|c|c|c|c|}
\hline Pegmatite & No. 503 & No. 503 & No. 503 & No. 503 & No. 503 & No. 503 & No. 503 & No. 503 & No. 503 & No. 503 & No. 503 & No. 503 & No. 503 \\
\hline $\mathrm{Yb}$ & b.d. & 0.05 & b.d. & b.d. & b.d. & b.d. & b.d. & b.d. & 0.07 & 0.02 & b.d. & b.d. & 0.05 \\
\hline $\mathrm{Lu}$ & b.d. & 0.00 & 0.01 & b.d. & b.d. & b.d. & b.d. & b.d. & 0.01 & 0.00 & b.d. & 0.01 & b.d. \\
\hline $\mathrm{Hf}$ & 219 & 149 & 314 & 97 & 103 & 61 & 60 & 712 & 959 & 340 & 278 & 111 & 105 \\
\hline $\mathrm{Ta}$ & 9460 & 5239 & 15,054 & 2639 & 5426 & 2135 & 1790 & 39,312 & 61,951 & 14,418 & 18,725 & 2729 & 10,112 \\
\hline W & 101 & 75 & 41 & 603 & 794 & 1457 & 1291 & 38 & 49 & 3 & 7 & 2 & 20 \\
\hline $\mathrm{Tl}$ & b.d. & b.d. & b.d. & 0.26 & 0.14 & b.d. & 0.06 & b.d. & 0.0 & b.d. & 0.1 & 0.0 & b.d. \\
\hline $\mathrm{Pb}$ & 2.2 & 2.7 & 2.3 & 2.5 & 5.3 & 2.9 & 2.5 & 1.1 & 2.1 & 0.6 & 0.5 & 1.1 & 20.1 \\
\hline $\mathrm{Bi}$ & b.d. & 0.02 & 0.10 & b.d. & b.d. & 0.02 & 0.10 & 0.01 & b.d. & b.d. & b.d. & 0.50 & 6.50 \\
\hline Th & 0.0 & 0.0 & 0.0 & 0.1 & 0.1 & 0.0 & b.d. & b.d. & b.d. & b.d. & 0.0 & b.d. & 0.3 \\
\hline $\mathrm{U}$ & 13.4 & 8.4 & 10.4 & 14.1 & 22.4 & 19.6 & 11.9 & 8.4 & 15.5 & 3.0 & 3.3 & 0.9 & 7.2 \\
\hline $\mathrm{Mn} /(\mathrm{Mn}+\mathrm{Fe})$ & 0.0 & 0.0 & 0.2 & 0.1 & 0.2 & 0.1 & 0.1 & 0.5 & 0.5 & 0.1 & 0.1 & 0.0 & 0.1 \\
\hline$\Sigma$ REE & 0.67 & 0.73 & 0.59 & 0.69 & 0.88 & 0.60 & 0.61 & 0.84 & 0.59 & 0.42 & 0.31 & 0.52 & 0.60 \\
\hline $\mathrm{Nb} / \mathrm{Ta}$ & 2.32 & 2.76 & 1.28 & 4.35 & 2.14 & 3.66 & 3.99 & 0.53 & 0.45 & 0.40 & 0.55 & 0.28 & 0.51 \\
\hline $\mathrm{Zr} / \mathrm{Hf}$ & 5.76 & 6.11 & 5.54 & 6.87 & 6.58 & 7.32 & 6.89 & 5.16 & 5.11 & 3.10 & 3.96 & 2.78 & 4.00 \\
\hline $\mathrm{Sn} / \mathrm{W}$ & 7226 & 9900 & 17,836 & 1245 & 952 & 509 & 582 & 17,647 & 13,515 & 273,523 & 102,069 & 480,328 & 33,604 \\
\hline
\end{tabular}



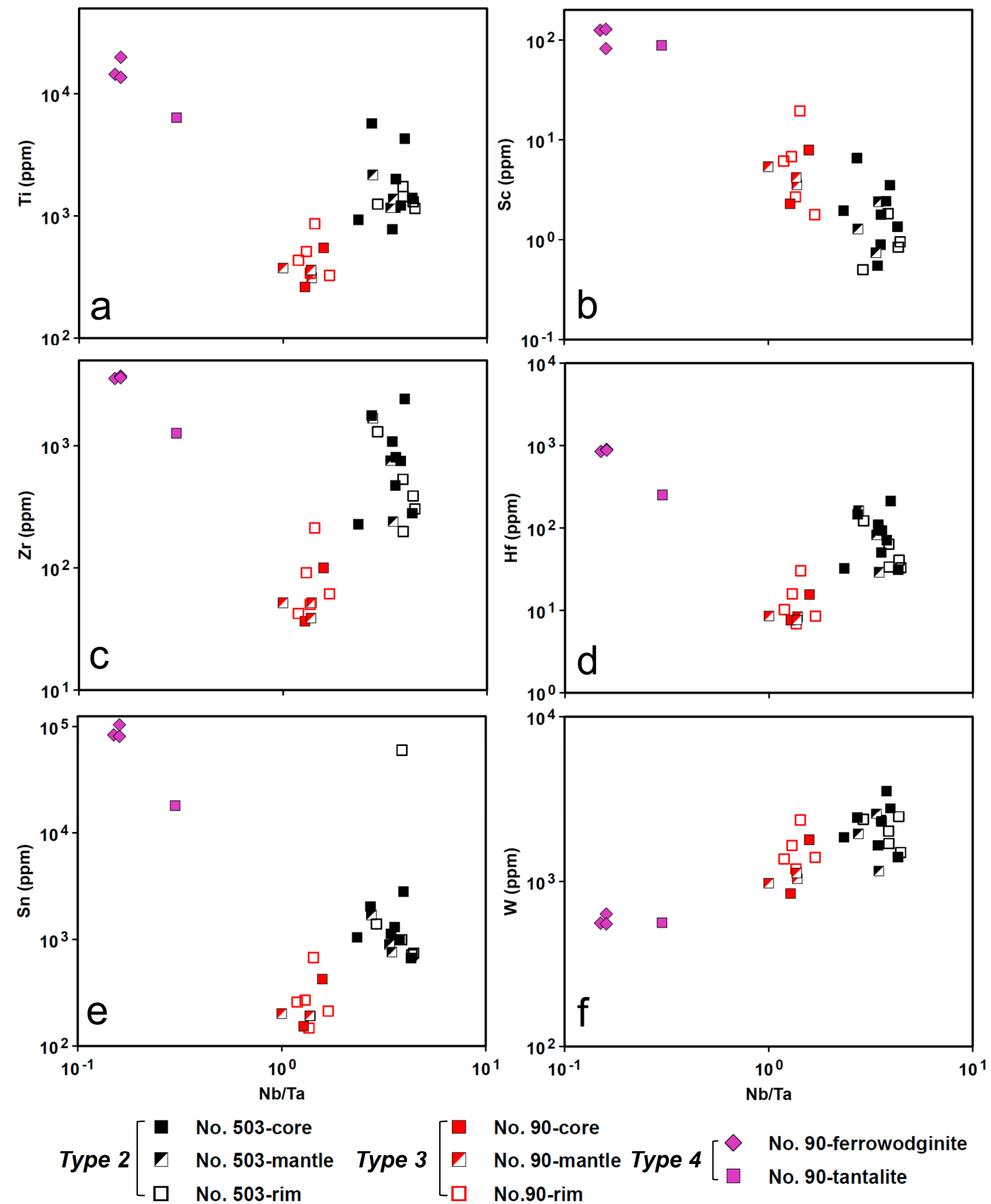

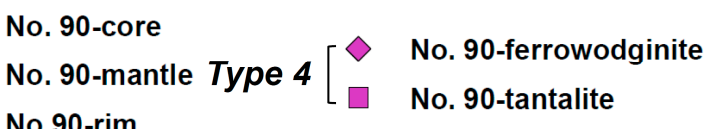

Figure 10. Binary plots of important trace elements versus $\mathrm{Nb}$ / Ta ratio for $\mathrm{Nb}$-Ta oxides from $\mathrm{No} .90$ and 503 pegmatites based on the concentrations of these elements obtained using LA-ICP-MS. (a) Ti vs. $\mathrm{Nb} / \mathrm{Ta}$; (b) Sc vs. Nb/Ta; (c) Zr vs. Nb/Ta; (d) Hf vs. Nb/Ta; (e) Sn vs. Nb/Ta; and (f) W vs. Nb/Ta.

\subsubsection{Cassiterite}

Cassiterite from No. 503 pegmatite exhibit highly variable $\mathrm{Fe}, \mathrm{Mn}, \mathrm{Zr}, \mathrm{Hf}, \mathrm{Nb}$, and $\mathrm{Ta}$ concentrations (Table 5). The cassiterite contains up to $8276 \mathrm{ppm} \mathrm{Fe}$, up to $7258 \mathrm{ppm} \mathrm{Mn}$, and 206-3255 Ti. The $\mathrm{Zr}$ and Hf concentrations mostly range between 417 and $1739 \mathrm{ppm}$ and between 105 and 340 ppm, respectively. Although the $\mathrm{Nb}$ and Ta concentrations can reach 28,119 and $61,951 \mathrm{ppm}$, respectively, most cassiterite contains 5830 to 19,455 ppm Nb and 2135 to 15,054 ppm $\mathrm{Ta}$. The concentrations of $\mathrm{Sc}, \mathrm{Rb}, \mathrm{Sr}, \mathrm{Cs}, \mathrm{Y}$, and REE in the cassiterite from No. 503 pegmatite are mostly below $2 \mathrm{ppm}$. The $\mathrm{W}$ concentrations are also highly variable, ranging from several ppm up 
to $1457 \mathrm{ppm}$. Moreover, the rim of cassiterite generally contains low Ti but high Ta and exhibits low $\mathrm{Nb} / \mathrm{Ta}$ ratio, compared to the core and mantle (Figure 11).
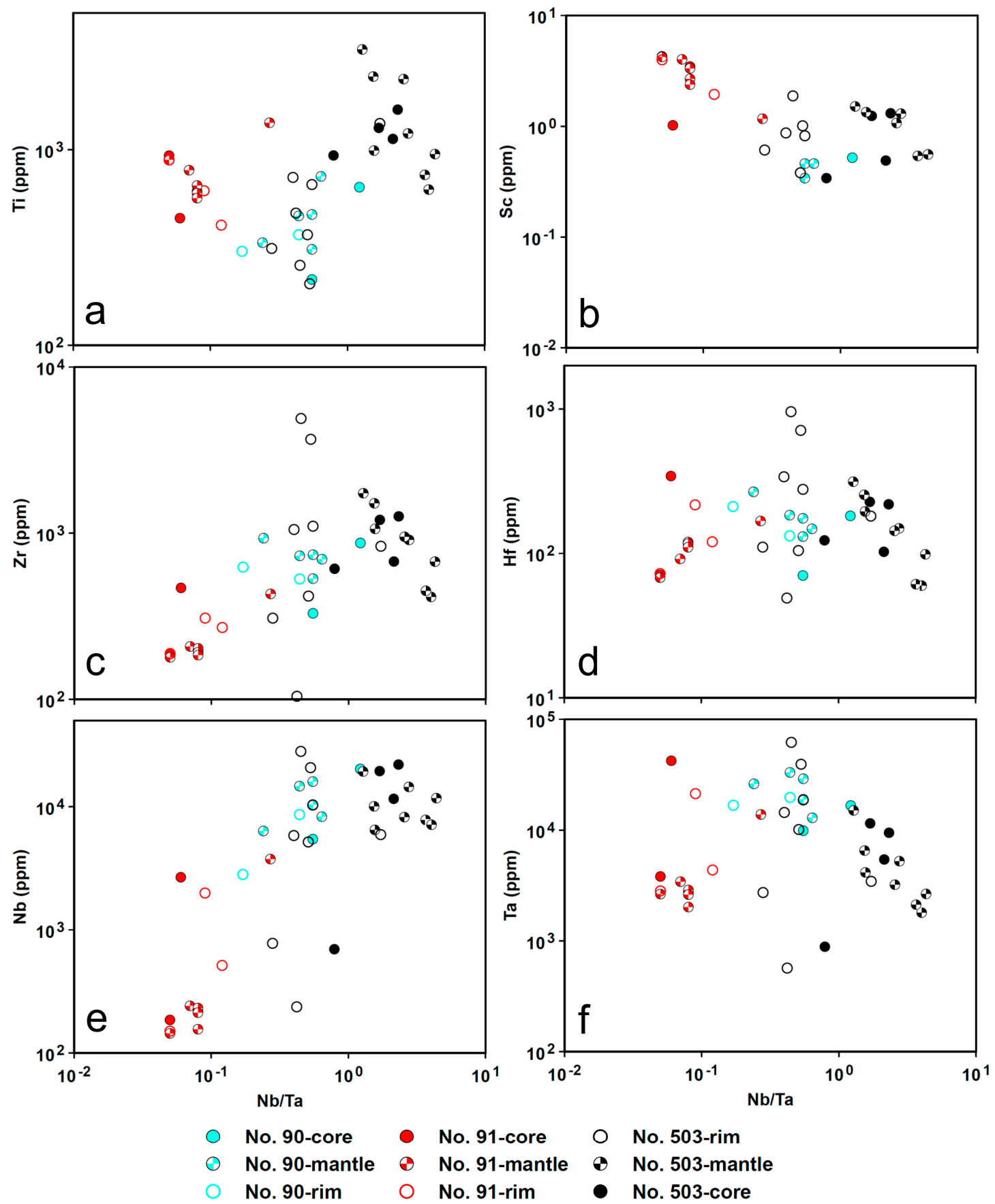

Figure 11. Binary plots of important elements versus Nb/Ta ratio for cassiterite from No. 90 and 503 pegmatites based on the results of LA-ICP-MS analysis. (a) Ti vs. Nb/Ta; (b) Sc vs. Nb/Ta; (c) Zr vs. $\mathrm{Nb} / \mathrm{Ta}$; (d) Hf vs. $\mathrm{Nb} / \mathrm{Ta}$; (e) $\mathrm{Nb}$ vs. $\mathrm{Nb} / \mathrm{Ta}$; and (f) $\mathrm{Ta}$ vs. $\mathrm{Nb} / \mathrm{Ta}$.

Most analyses on the cassiterite from No. 90 pegmatite show 960-1618 ppm Si, 152-468 ppm Fe, 36-92 ppm Mn, 411-1373 ppm Ti, 179-270 ppm Zr, 68-120 ppm Hf, 144-514 ppm Nb, and 2018-4359 ppm Ta (Table 5). Three analyses on one cassiterite grain (Sample ID 26-13.4) exhibit significantly higher Mn (104-455 ppm), Fe (2676-6795 ppm), Nb (1989-3753 ppm), Ta (13,835-42,260 ppm), $\mathrm{Zr}(308-468 \mathrm{ppm})$, and Hf (168-344 ppm) than the rest analyses. The concentrations of LILE including 
$\mathrm{Rb}, \mathrm{Sr}, \mathrm{Ba}$, and $\mathrm{Cs}, \mathrm{Sc}, \mathrm{W}, \mathrm{U}$, and $\mathrm{Pb}$ are also low, commonly below $5 \mathrm{ppm}$. In addition, $\mathrm{Y}$ and $\mathrm{REE}$ concentrations are mainly below the detection limits.

Compared to cassiterite from No. 90 pegmatite, cassiterite from No. 91 pegmatite contains relatively high but variable Fe (2912-9130 ppm), Mn (87-410 ppm), Ti (217-730 ppm), Zr (329-933 ppm), Hf (70-267 ppm), Nb (2816-20,256 ppm), and Ta (9871-33,120 ppm) concentrations (Table 5). Lithium concentration mostly varies between 2.8 and $6.9 \mathrm{ppm}$. The concentrations of $\mathrm{Rb}, \mathrm{Sr}$, and $\mathrm{Cs}$ are mainly below $5 \mathrm{ppm}$. For the majority of the cassiterite grains from No. 91 pegmatite, Sc, Y, and REE concentrations are mainly below the detection limits.

The cassiterite from the three pegmatites mainly shows difference in concentrations of Sc, $\mathrm{Zr}$, and $\mathrm{Nb}$ and $\mathrm{Nb} / \mathrm{Ta}$ ratio. The Ti concentrations of cassiterite from different pegmatites basically vary in a similar range (Figure 11a). The cassiterite from No. 90 pegmatite contains higher Sc concentrations but lower $\mathrm{Zr}$ and $\mathrm{Nb}$ concentrations than those from No. 91 and No. 503 pegmatites (Figure 11b,c,e). The cassiterite from the three pegmatites contains similar Hf and Ta concentrations (Figure 11d,f). Moreover, the cassiterite from No. 90 pegmatite is characterized by relatively low $\mathrm{Nb} / \mathrm{Ta}$ ratio, compared with the cassiterite from the other two pegmatites.

\section{Discussion}

\subsection{Origin of Cassiterite and CGM}

Although cassiterite can either crystallize from melts or form hydrothermally in granitic pegmatites $[12,49,50]$, no distinct difference in morphology has been recognized between magmatic and hydrothermal cassiterite. For example, Pal et al. [12] showed that magmatic cassiterite along with CGM and Hf-zircon occurred as irregular inclusions in hydrothermal cassiterite. In some $\mathrm{Sn}-\mathrm{Ta}-\mathrm{Nb}$ mineralized pegmatites from Manono-Kitotolo, hydrothermal cassiterite reached centimeters in size, much larger than magmatic cassiterite [50]. In this study, cassiterite mostly occurs as single crystals with grain sizes up to $\mathrm{cm}$ in all the studied AbSpd pegmatites and exhibits euhedral crystal habit. Yan et al. [21] suggested that the cassiterite was magmatic because cassiterite was associated with coarse-grained albite and quartz that likely formed at an early magmatic stage in No. 90 pegmatite. Another way to determine the origin of cassiterite is to look at the correlation between $\mathrm{Nb}+\mathrm{Ta}$ and $\mathrm{Fe}+$ $\mathrm{Mn}$ in cassiterite. As showed in [13,47], $\mathrm{Nb}+\mathrm{Ta}$ and $\mathrm{Fe}+\mathrm{Mn}$ values (in a.p.f.u.) of magmatic cassiterite generally plot along the 2: 1 line on the $\mathrm{Nb}+\mathrm{Ta}$ versus $\mathrm{Fe}+\mathrm{Mn}$ binary diagram whereas hydrothermal cassiterite shows no such correlation. Figure 8 shows that the data points of the cassiterite from all three pegmatites also plot on the same linear array as the magmatic cassiterite did in $[13,47]$. This indicates that the cassiterite in this study is likely of magmatic origin. The 2:1 ratio between $\mathrm{Nb}+\mathrm{Ta}$ and $\mathrm{Fe}+\mathrm{Mn}$ is related to the substitution $2(\mathrm{Nb}, \mathrm{Ta})^{5+}+(\mathrm{Fe}, \mathrm{Mn})^{2+}=3 \mathrm{Sn}^{4+}$ proposed by $[46,47]$.

Four types of CGM have been identified based on their occurrence and morphology. Types 1 and 2 CGM are magmatic because: (1) Type 1 CGM occurs as inclusions (showing no orientation) in the magmatic cassiterite (Figure 5f); (2) Type 2 CGM exhibits oscillatory zoning and sector zoning in some cases (Figure 5a), which is typical for magmatic CGM [8,51]; and (3) Type 2 CGM is likely at equilibrium with the magmatic cassiterite as indicated by their planar contact (Figure $4 \mathrm{~d}$ ). The textural relationships also suggest that Type 1 CGM was earlier than Type 2 CGM. Although Type 3 CGM is associated with the same mineral assemblage as Type 2 CGM, no direct contact between these two types has been observed. Unlike Type 2 CGM, Type 3 CGM occurs as aggregates and shows a complicated internal texture with patchy Ta-Fe-rich domains at the margins of crystals or along fractures (Figure $5 \mathrm{c}$ ). Such feature is likely related to late-stage metasomatic replacement caused by highly reactive fluids exsolved from the residual melts [11]. Also, according to [11], it is common that an early columbite generation can be partially to completely replaced by a later, Ta-richer columbite-tantalite generation. Therefore, Type 3 CGM should have formed later than Type 2 CGM and might be a metasomatic product of Type 2 CGM. Type 4 CGM is intergrown with ferrowodginite and both minerals exhibit patchy textures (Figure 4d). In many Li-rich pegmatites, the trend of crystallization of primary 
Ta-Nb-Sn oxides generally corresponds to progressive $\mathrm{Fe} \rightarrow \mathrm{Mn}$ and $\mathrm{Nb} \rightarrow \mathrm{Ta}$ substitutions in these oxides during magmatic fractionation and wodginite as a rare final product of such fractionation is commonly Mn-Ta-rich [9,52]. However, the ferrowodginite and its associated CGM in this study are both Fe-rich. These CGM-ferrowodginite intergrowths show similarities with the tantalite-(Fe) + ferrowodginite assemblage in some of the Separation Rapids pegmatites (cf. [52]). The latter represents the highly evolved product of an evolutionary sequence from columbite-(Fe) to columbite-(Fe) + ferrowodginite to tantalite-(Fe) + ferrowodginite to microlite-group minerals (the paths for beryl pegmatites and spodumene pegmatites in Figure 6) [52]. Therefore, in No. 90 pegmatite, the Type 4 CGM-ferrowodginite intergrowths could be magmatic but formed later than Type 2 CGM that is compositionally columbite-(Fe). In summary, based on petrographic observations, the crystallization sequence of the $\mathrm{Nb}$-Ta-Sn oxide minerals in the Dahongliutan AbSpd pegmatites can be described as: Type 1 CGM (as inclusions in cassiterite) $\rightarrow$ Type 2 CGM + cassiterite $\rightarrow$ Type 3 CGM or $\rightarrow$ Type 4 CGM + ferrowodginite. It is difficult to make a judgement on the crystallization sequence between types 3 and 4 CGM + ferrowodginite solely based on textural relationships. Their crystallization sequence will be further elucidated from a perspective of $\mathrm{Nb}-\mathrm{Ta}$ and $\mathrm{Mn}-\mathrm{Fe}$ fractionation in the next section.

\subsection{Chemical Evolution of Cassiterite and CGM within a Single Pegmatite}

In this study, our LA-ICP-MS analyses show that the concentrations of LILE, REE, Y, U, Th, and Pb are extremely low in CGM and cassiterite and do not show any distinct variation patterns. Therefore, we only focus on elements including $\mathrm{Zr}, \mathrm{Hf}, \mathrm{Nb}, \mathrm{Ta}, \mathrm{W}, \mathrm{Sn}, \mathrm{Ti}$, and $\mathrm{Sc}$ that are commonly present in CGM and cassiterite and have been mentioned in the literature.

\subsubsection{No. 503 Pegmatite}

In No. 503 pegmatite, it is obvious that the rim of cassiterite mostly contains higher Ta concentrations and shows lower $\mathrm{Nb} / \mathrm{Ta}$ and $\mathrm{Zr} / \mathrm{Hf}$ ratios than the core and mantle (Figure 12). Thus, the crystallization of the cassiterite likely reflects $\mathrm{Nb}$-Ta and $\mathrm{Zr}$-Hf fractionation in No. 503 pegmatite and the composition of cassiterite evolved towards a Ta- and Hf-richer composition. Such $\mathrm{Nb}$-Ta and Zr-Hf fractionation are commonly reflected by Nb-Ta oxides (typically CGM) and zircon, respectively, in high evolved LCT-family pegmatites [37]. According to [37], the trends of $\mathrm{Nb} / \mathrm{Ta}$ versus Ta in CGM and Zr/Hf versus Hf in zircon are right-declined and linear with almost identical slopes, with increasing fractionation degree of pegmatites. Linnen and Cuney [53] pointed out that such fractionation trends were likely due to different solubilities of end-member phases in CGM and zircon, respectively. According to their study, because columbite and zircon have lower solubilities than tantalite and hafnon, respectively, in metaluminous to peraluminous granitic melts, the granitic melts would be Ta- and Hf-richer with increasing fractionation degree. Recently, Van Lichtervelde et al. [54] argued that isothermal $\mathrm{Nb}$-Ta fractionation cannot be explained by solubility differences. Rather, disequilibrium crystallization at supersaturation should be the reason for extreme Ta enrichment in residual melts [54]. To date, little attention has been paid to $\mathrm{Nb} / \mathrm{Ta}$ and $\mathrm{Zr} / \mathrm{Hf}$ ratios in cassiterite (e.g., [55]). In this study, on $\mathrm{Nb} / \mathrm{Ta}$ versus $\mathrm{Zr} / \mathrm{Hf}$ binary plot (Figure 12a), it is noticeable that $\mathrm{Nb} / \mathrm{Ta}$ and $\mathrm{Zr} / \mathrm{Hf}$ ratios of the cassiterite from No. 503 pegmatite show a positive correlation. Because the cassiterite is a primary phase in the pegmatite and can incorporate $\mathrm{Nb}, \mathrm{Ta}, \mathrm{Zr}$, and Hf into its structure through substitution [19], it is expected that the $\mathrm{Nb} / \mathrm{Ta}$ and $\mathrm{Zr} / \mathrm{Hf}$ ratios of the cassiterite potentially reflect the $\mathrm{Nb}$-Ta and $\mathrm{Zr}$-Hf fractionation of the pegmatite melts as in this case. Černý et al. [46] also suggested that the compositional trend of cassiterite is from $\mathrm{Nb}$-rich to Ta-rich cassiterite in lepidolite-subtype pegmatites. In addition, the $\mathrm{Sn} / \mathrm{W}$ and $\mathrm{Nb} / \mathrm{Ta}$ ratios show a negative correlation and the $\mathrm{Sn} / \mathrm{W}$ ratios generally increase from core and mantle to rim (Figure 12b). Möller et al. [56] suggested that $\mathrm{W}$ enters cassiterite via the substitution $\mathrm{W}^{6+}+2 \mathrm{Fe}^{3+}=3 \mathrm{Sn}^{4+}$. Hence, the incorporation of $\mathrm{W}$ into cassiterite is controlled by the availability of $\mathrm{Fe}^{3+}$ that is affected by oxygen fugacity. In this study, charge balance calculations based on EPMA data indicate that $\mathrm{Fe}^{3+}$ in cassiterite is minimal and that $\mathrm{Fe}$ is predominantly $\mathrm{Fe}^{2+}$ (Table 2). Because both EPMA and LA-ICP-MS analyses have revealed 
that $\mathrm{W}$ concentration is much lower than $\mathrm{Fe}, \mathrm{Nb}$, and Ta concentrations in most cassiterite (Tables 2 and 5), the correlation between Fe and W is likely overshadowed by the correlation between Fe $+\mathrm{Mn}$ and $\mathrm{Nb}+\mathrm{Ta}$. Therefore, it is not sure whether the $\mathrm{Sn} / \mathrm{W}$ ratios of cassiterite could be affected by change in oxygen fugacity at this moment. Alternatively, the $\mathrm{Sn} / \mathrm{W}$ ratios of cassiterite could be influenced by the growth of Type 2 CGM because the CGM appears to be a main carrier of $W$ and exhibits consistent $\mathrm{Sn} / \mathrm{W}$ ratios, incorporating up to $3549 \mathrm{ppm} \mathrm{W}$ (Table 5). As the CGM incorporated significant W into its structure, there would be less $W$ available for cassiterite, which resulted in increase in the $S n / W$ ratios of cassiterite. Compared to the cassiterite, Type 2 CGM exhibits extremely low Sn/W ratios (mostly below 1) (Figure 12b) and high W concentrations (1157-3549 ppm). This may indicate that CGM strongly favors $\mathrm{W}$ and would control incorporation of $\mathrm{W}$ into cassiterite if CGM and cassiterite crystalize at the same moment.

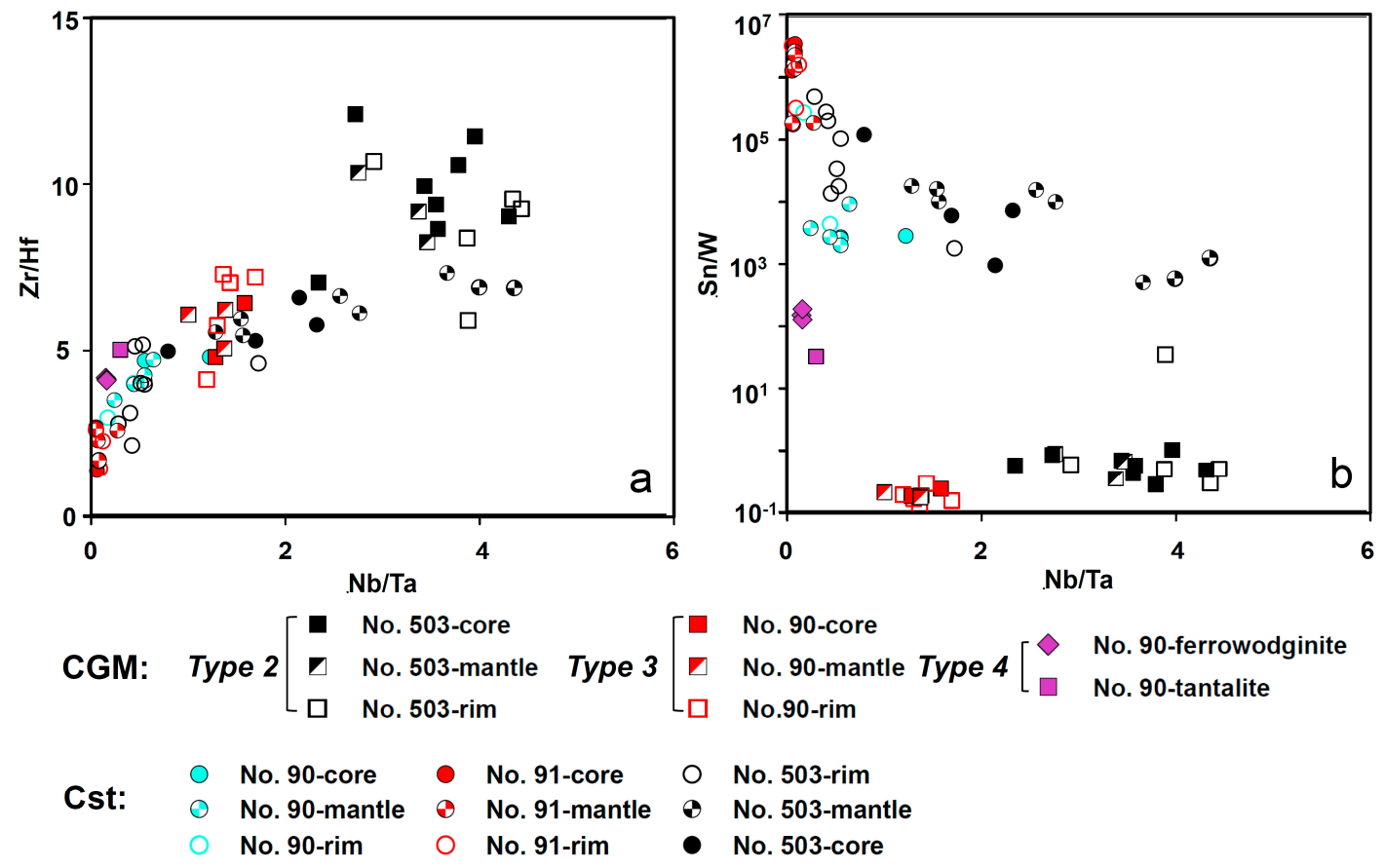

Figure 12. (a) $\mathrm{Zr} / \mathrm{Hf}$ versus $\mathrm{Nb} / \mathrm{Ta}$ plots and (b) $\mathrm{Sn} / \mathrm{W}$ versus $\mathrm{Nb} / \mathrm{Ta}$ for $\mathrm{Nb}$ - $\mathrm{Ta}$ oxides and cassiterite, respectively. Ratios are calculated base the results of LA-ICP-MS analyses of both CGM and cassiterite. See text for detailed explanation on the variations in $\mathrm{Nb} / \mathrm{Ta}, \mathrm{Zr} / \mathrm{Hf}$, and $\mathrm{Sn} / \mathrm{W}$ ratios of $\mathrm{CGM}$ and cassiterite.

In this pegmatite, Type $2 \mathrm{CGM}$ shows no distinct variation patterns for $\mathrm{Ti}, \mathrm{Sc}, \mathrm{Zr}, \mathrm{Hf}, \mathrm{Sn}$, and $\mathrm{W}$ from core to rim (Figure 10). The $\mathrm{Nb} / \mathrm{Ta}$ ratios of Type $2 \mathrm{CGM}$ vary in a relatively narrow range (2.3-4.4), compared to the cassiterite in the same pegmatite (Figure 12). The $\mathrm{Zr} / \mathrm{Hf}$ and $\mathrm{Sn} / \mathrm{W}$ ratios of most Type 2 CGM are consistent, ranging from 8 to 10.5 and from 0.4 to 0.7 , respectively. Also, the $\mathrm{Nb} / \mathrm{Ta}$ ratios of Type 2 CGM exhibit no clear correlation with either $\mathrm{Zr} / \mathrm{Hf}$ ratios or $\mathrm{Sn} / \mathrm{W}$ ratios (Figure 12). As mentioned, the textural relationship between Type 2 CGM and cassiterite suggests that these two minerals are mostly at equilibrium (Figure 4d). If Type 2 CGM and cassiterite were coeval, the $\mathrm{Nb} / \mathrm{Ta}, \mathrm{Zr} / \mathrm{Hf}$, and $\mathrm{Sn} / \mathrm{W}$ ratios of Type 2 CGM should also change. However, unlike the cassiterite whose compositional variations reflect $\mathrm{Nb}$-Ta and $\mathrm{Zr}$-Hf fractionation of the pegmatite melt, Type 2 CGM may have crystallized in a stable environment, as indicated by the consistent trace element concentrations and $\mathrm{Nb} / \mathrm{Ta}, \mathrm{Zr} / \mathrm{Hf}$, and $\mathrm{Sn} / \mathrm{W}$ ratios. The distinctly different compositional variation patterns exhibited by Type 2 CGM and cassiterite could be explained by their different growth history. In other words, Type 2 CGM is only in equilibrium with part of the cassiterite (either the core and mantle or the rim). If the CGM only grew coevally with the cassiterite rim, the core and mantle of the cassiterite should not exhibit planar contact with Type 2 CGM, as showed in Figure 4d. Rather, the 
core and mantle of the cassiterite should be separated from Type 2 CGM and/or other minerals by the rim of the cassiterite. Therefore, we propose that Type 2 CGM is in equilibrium with the core and mantle of the cassiterite.

\subsubsection{No. 90 Pegmatite}

In No. 90 pegmatite, cassiterite is characterized by low $\mathrm{Nb} / \mathrm{Ta}$ and $\mathrm{Zr} / \mathrm{Hf}$ ratios (Figure 12a). The cassiterite shows high $\mathrm{Sn} / \mathrm{W}$ ratios, corresponding to extremely low $\mathrm{W}$ concentration $(<5 \mathrm{ppm})$ (Table 5). No certain correlation between $\mathrm{Nb} / \mathrm{Ta}$ and $\mathrm{Zr} / \mathrm{Hf}$ or between $\mathrm{Nb} / \mathrm{Ta}$ and $\mathrm{Sn} / \mathrm{W}$ can be recognized possibly due to the extremely low $\mathrm{Nb} / \mathrm{Ta}$ ratios.

No. 90 pegmatite shows complicated mineralogical evolution of $\mathrm{Nb}$-Ta oxides that is defined by a trend from Type 2 CGM (columbite-(Fe)) + cassiterite $\rightarrow$ Type 3 CGM (columbite-(Mn)) or $\rightarrow$ Type 4 CGM (tantalite-(Fe)) + ferrowodginite (Figure 6). Type 2 CGM coexisting with the cassiterite exhibits consistent $\mathrm{Mn} /(\mathrm{Mn}+\mathrm{Fe})$ and $\mathrm{Ta} /(\mathrm{Ta}+\mathrm{Nb})$ and no distinct variations ([21]; also see the area circled by a blue line in Figure 6). According to [21], Type 2 CGM exhibits consistent Sn/W ratios (mostly between 0.08 and 0.29 ) and no correlation between $\mathrm{Nb} / \mathrm{Ta}$ and $\mathrm{Sn} / \mathrm{W}$ ratios of Type 2 CGM can be recognized.

Type 3 CGM which formed after Type 2 CGM is generally Mn- and Ta-richer than Type 2 CGM. The overall compositional change from Type 2 CGM to Type 3 CGM is consistent with the typical evolutionary trend described for many LCT pegmatites (e.g., Kolmozero [8]; Separation Rapids [11]; Jálama [14]). It is also noticeable that the $\mathrm{Mn} /(\mathrm{Fe}+\mathrm{Mn})$ ratio decreases whereas the $\mathrm{Ta} /(\mathrm{Ta}+\mathrm{Nb})$ increases from core to rim in Type 3 CGM (Figure 6). This indicates that CGM evolved towards a Feand Ta-richer composition during the growth of Type 3 CGM.

Type 4 CGM and ferrowodginite are both Fe- and Ta-richer than types 2 and 3 CGM (Figure 6). As discussed above, Type 4 CGM and ferrowodginite formed after Type 2 CGM but no textural relationships revealing the crystallization sequence between types 3 and 4 CGM have been observed. If Type 3 CGM crystallized before Type 4 CGM + ferrowodginite, then the evolutionary trend would be Type 2 CGM (columbite-(Fe)) + cassiterite $\rightarrow$ Type 3 CGM (columbite-(Mn)) $\rightarrow$ Type 4 CGM (tantalite-(Fe) + ferrowodginite, which shows progressive $\mathrm{Nb}$-Ta fractionation. Compared to Type 3 CGM, the relatively low $\mathrm{Zr} / \mathrm{Hf}$ ratios of Type $4 \mathrm{CGM}$ + ferrowodginite also indicate obvious $\mathrm{Zr}$-Hf fractionation. This trend is unusual, compared with other LCT pegmatites showing extensive $\mathrm{Nb}-\mathrm{Ta}$ fraction but limited Mn-Fe fractionation (e.g., Jálama [1,4]; some Li-rich pegmatites at Separation Rapids [52]; La Viquita spodumene pegmatite [57]). The reversed Mn-Fe fractionation trend may be explained by interaction between pegmatite melts with the wallrock [52,57]. Tindle et al. [52] suggested that the interaction between the pegmatite-derived fluids and the wallrock could release $\mathrm{Ti}$ and Fe into the residual melt to produce Ti-Fe-rich wodginite. This hypothesis can also explain the occurrence of tantalite-(Fe)-ferrowodginite intergrowths confined to the WZ. Triphylite-lithiophilite series is commonly considered as a primary phase in LCT pegmatites [37-40]. The triphylite which is the Fe-Mn-richest mineral and abundant in No. 90 pegmatite evolves towards Mn-richer compositions (Figure 9a,b), using Li content as an indicator. However, the low Mn/(Mn + Fe) value $(<0.5)$ of triphylite suggests that the crystallization of this phase cannot be responsible for the reversed Mn-Fe fractionation. If Type 3 CGM crystallized later than Type 4 CGM + ferrowodginite, reversed $\mathrm{Nb}$-Ta fractionation at a late stage, which has rarely been reported in the literature, is then required. Nevertheless, compared to reversed $\mathrm{Mn}$-Fe fractionation, reversed $\mathrm{Nb}$-Ta fractionation is difficult to happen for the following reasons. Firstly, although hydrothermal replacement can potentially fractionate $\mathrm{Nb}$ from Ta, Novák and Černý [58] showed that $\mathrm{Nb}$ and Ta had limited mobility under hydrothermal conditions and that the $\mathrm{Nb} / \mathrm{Ta}$ ratios of the secondary phases were comparable to those of their precursors. Secondly, competition for $\mathrm{Nb}$ and $\mathrm{Ta}$ is mainly restricted to $\mathrm{Nb}$-Ta-Sn-Ti oxides and possibly mica in pegmatites, unlike competition for Mn and Fe occurring between a variety of minerals such as mica, phosphates (e.g., triphylite in this study), tourmaline and oxides. Finally, considering that Type 3 CGM became Fe- 
and Ta-richer during its growth, it would be reasonable to assume that Type 4 CGM and ferrowodginite formed after Type 3 CGM.

From Type 3 CGM to Type 4 CGM + ferrowodginite, the compositional trend is characterized by significant increase in $\mathrm{Ti}, \mathrm{Sc}, \mathrm{Zr}, \mathrm{Hf}$, and $\mathrm{Sn}$ and slight decrease in $\mathrm{W}$, accompanied by decreased $\mathrm{Mn} / \mathrm{Fe}$ (Figure 10). Titanium and Sc could be derived from the wallrock or accumulate in residual melts through magmatic fractionation and partition into late generations of $\mathrm{Nb}$-Ta oxides [59]. In this case, Ti could be derived from the wallrock because $\mathrm{TiO}_{2}$ contents decrease from $0.70 \pm 0.11 \mathrm{wt}$. \% in Type 2 CGM to $0.23 \pm 0.19$ wt. \% in Type 3 CGM but increase significantly in Type 4 CGM + ferrowodginite $\left(2.03 \pm 1.77 \mathrm{wt}\right.$. \% $\left.\mathrm{TiO}_{2}\right)$. Scandium is likely incorporated into CGM via a euxenite-type substitution $(\mathrm{Fe}, \mathrm{Mn})^{2+}+(\mathrm{Nb}, \mathrm{Ta})^{5+}=\mathrm{Sc}^{3+}+\mathrm{Ti}^{4+}$, according to [60]. Thus, increased Ti activity would facilitate incorporation of Sc into CGM. Type 2 CGM from No. 90 pegmatite has not been analyzed for Sc using LA-ICP-MS and some Sc concentrations obtained using EPMA are close to the detection limit and may not be precise. For this reason, whether Sc accumulates in the course of magmatic fractionation remains unclear. Zirconium is regarded as a primary component of the pegmatite melt [57]. Due to low mobility, Hf is likely derived from the pegmatite melt, similar to Zr. The increased Sn activity during the formation of Type 4 CGM + ferrowodginite is not clear. One possibility is that the residual melt interacted with Sn-bearing fluids exsolved from the pegmatite at earlier stages to produce wodginite-group minerals [61]. According to [62], Sn can partition into the fluid phase when a high saline fluid is exsolved from a $\mathrm{H}_{2} \mathrm{O}$-saturated $\mathrm{Sn}$-rich melt. The exsolution of $\mathrm{Sn}$-bearing fluids after the crystallization of early cassiterite could also explain the decreased Sn activity during the formation of Type 3 CGM. Tungsten concentrations in the $\mathrm{Nb}$-Ta oxides continuously decrease from Type 2 CGM (containing $1.10 \pm 0.23$ wt. $\% \mathrm{WO}_{3}$ or $8723 \pm 1824 \mathrm{ppm}$ [21]) to Type 3 CGM (containing $1375 \pm 456 \mathrm{ppm} \mathrm{W}$ ) to Type 4 CGM + ferrowodginite ( $577 \pm 39 \mathrm{ppm} \mathrm{W})$, which is likely the result of magmatic fractionation [59].

\subsubsection{No. 91 Pegmatite}

In No. 91 pegmatite, cassiterite also shows a positive correlation between $\mathrm{Nb} / \mathrm{Ta}$ and $\mathrm{Zr} / \mathrm{Hf}$ ratios (Figure 12a). However, the $\mathrm{Nb} / \mathrm{Ta}$ and $\mathrm{Sn} / \mathrm{W}$ ratios of the cassiterite do not exhibit any correlation (Figure 12b). Type 2 CGM which is the only CGM type in this pegmatite shows decreasing $\mathrm{Nb} / \mathrm{Ta}$ (or increasing \#Ta) from core to rim (Figure 6). Due to the small size, no LA-ICP-MS analyses were conducted for determining $\mathrm{Zr}$ and Hf concentrations of Type 2 CGM in this pegmatite. Therefore, the correlation between $\mathrm{Nb} / \mathrm{Ta}$ and $\mathrm{Zr} / \mathrm{Hf}$ ratios of Type $2 \mathrm{CGM}$ cannot be investigated in this study. The $\mathrm{Sn} / \mathrm{W}$ ratios $(0.86 \pm 0.21)$ of the core of Type 2 CGM are comparable to those $(0.68 \pm 0.37)$ of the rim, based on EPMA analysis (Table 1).

\subsection{Chemical Evolution of Cassiterite and CGM within the Pegmatite Group}

The Zircon U-Pb ages ( $220 \pm 2.2 \mathrm{Ma}$ to $217 \pm 2.2 \mathrm{Ma})$ for the Dahongliutan Granite obtained by [34] are comparable to the columbite and cassiterite $\mathrm{U}-\mathrm{Pb}$ age $(211.9 \pm 2.4 \mathrm{Ma}$ and $218 \pm 12 \mathrm{Ma})$ for No. 90 pegmatite obtained by [21]. Considering that the regional zonation of the pegmatites around the Dahongliutan Granite mimics the typical zonation pattern for LCT-type pegmatites and their parental granites [37], the Dahongliutan Granite may be the parental granite for the AbSpd pegmatites [20,21]. Moreover, according to our field observations, No. 503, No.91, and No. 90 AbSpd pegmatites are distributed with an increasing horizontal distance from the Dahongliutan Granite (Figure 1b). In this study, we compare the compositions of the coexisting cassiterite and CGM (Type 2) from these three pegmatites to investigate the chemical evolution of magmatic cassiterite and CGM within a pegmatite group. For convenience reasons, Type 2 CGMs from No. 503, 91, and 90 pegmatites are designated CGM2_503, CGM2_91, and CGM2_90, respectively. Similarly, the cassiterites from No. 503, 91, and 90 pegmatites are designated Cst_503, Cst_91, and Cst_90, respectively.

Figure 6 shows that Type 2 CGM from all the pegmatites (except the rim of CGM2_91) exhibits similar \# $\mathrm{Ta}$ (or $\mathrm{Nb} / \mathrm{Ta}$ ). Because the $\mathrm{Nb}$ and $\mathrm{Ta}$ are mainly controlled by the $\mathrm{CGM}$, the similar $\mathrm{Nb} / \mathrm{Ta}$ 
ratios of the CGM may indicate that the pegmatite-forming melts had similar $\mathrm{Nb} / \mathrm{Ta}$ ratios, if Type 2 CGM crystallized under similar physicochemical conditions (temperature, pressure, oxygen fugacity, etc.). In other words, the pegmatite-forming melts could exhibit identical Ta enrichment when Type 2 CGM crystallized. Nevertheless, unlike their coexisting CGM, Cst_503, Cst_91, and Cst_90 show inconsistent $\mathrm{Nb} / \mathrm{Ta}$ ratios (Figure 12), which implies that the CGM-cassiterite assemblages were formed under different conditions, given that cassiterite/melt partition coefficients for $\mathrm{Nb}$ and $\mathrm{Ta}$ in presence of CGM change with T and P in a consistent way. In addition, both No. 90 and 91 pegmatites could experience interaction with wallrock, as indicated by the reversed $\mathrm{Mn}$-Fe trend (i.e., the occurrence of tantalite-(Fe) + ferrowodginite in No. 90 pegmatite and Type 2 CGM showing Fe-Ta-rich rim in No. 91 pegmatite) [52]. In contrast, types 1 and 2 CGM in No. 503 pegmatite show no such reserved $\mathrm{Mn}-\mathrm{Fe}$ fractionation, likely indicating limited interaction with wallrock. The $\mathrm{Zr} / \mathrm{Hf}$ ratios of CGM2_90 and CGM2_91 have not been obtained in this study. Therefore, we cannot compare Type 2 CGM from different pegmatites in terms of $\mathrm{Zr} / \mathrm{Hf}$ ratio.

CGM2_90 exhibits lower Sn/W ratio than CGM2_91 and CGM2_503 (Figure 12b). Because the $\mathrm{SnO}_{2}$ contents of Type 2 CGMs are similar (Table 1), the difference in $\mathrm{Sn} / \mathrm{W}$ ratios mainly depends on the $\mathrm{W}$ concentrations of Type 2 CGM, which could be explained by (1) different $\mathrm{W}$ concentrations in the pegmatite-forming melts and/or (2) difference in crystallization conditions (temperature, pressure, etc.). Constraints on the crystallization temperature and pressure of Type 2 CGM and knowledge of $\mathrm{CGM} /$ melt and CGM/cassiterite partition coefficients for $\mathrm{W}$, which is not available in the literature, are required for examining these two possibilities.

Cst_503, Cst_91, and Cst_90 also show inconsistent $\mathrm{Zr} / \mathrm{Hf}$ and Sn/W ratios. The core and mantle of Cst_503 exhibits the highest Zr/Hf ratios (Figure 12). The rim of Cst_503 shows decrease in $\mathrm{Zr} / \mathrm{Hf}$ ratio but increase in Sn/W ratio. Cst_91 exhibits a $\mathrm{Zr} / \mathrm{Hf}$ ratio similar to that of the rim of Cst_503 and $\mathrm{Sn} / \mathrm{W}$ ratio similar to that of the core of Cst_503. In general, Cst_90 shows the lowest $\mathrm{Zr} / \mathrm{Hf}$ ratio but the highest $\mathrm{Sn} / \mathrm{W}$ ratio. The $\mathrm{Sn} / \mathrm{W}$ ratio of cassiterite is strongly influenced by the coexisting CGM because CGM and cassiterite appear to be the only two carriers of $W$ and compete for W. For instance, CGM2_90 contains the higher $\mathrm{WO}_{3}$ content than CGM2_91 and CGM2_503. Correspondingly, Cst_90 exhibits the higher Sn/W ratio than Cst_91 and Cst_503. Also, the $\mathrm{WO}_{3}$ content $(0.34 \pm 0.14$ wt. \%) of CGM2_503 is comparable to that $(0.26 \pm 0.11 \mathrm{wt}$. \%) of CGM2_91 (Supplementary Materials S2). Correspondingly, the $\mathrm{Sn} / \mathrm{W}$ ratio of Cst_91 is comparable to that of the core and mantle of Cst_503 that are in equilibrium with CGM2_503 (Figure 12b). Because the CGM-cassiterite were likely formed under different conditions (e.g., different temperatures), the CGM/cassiterite partition coefficient for W were hypothetically different.

\section{Conclusions}

The CGMs in the investigated Dahongliutan albite-spodumene pegmatites (No. 503, No. 91, and No. 90) can be broadly classified into four types: (1) mineral inclusions in cassiterite; (2) euhedral to subhedral crystals (commonly exhibiting oscillatory and/or sector zoning); (3) anhedral mineral aggregates; (4) tantalite-(Fe)-ferrowodginite intergrowths. Cassiterite coexisting with Type 2 CGM is present in all three pegmatites and is of magmatic origin, showing a positive correlation (2:1) between $\mathrm{Nb}+\mathrm{Ta}$ (a.p.f.u.) and $\mathrm{Fe}+\mathrm{Mn}$ (a.p.f.u.) that is similar to that of typical magmatic cassiterite.

Among the three pegmatites, No. 90 pegmatite shows the most complicated evolution of the $\mathrm{Nb}-\mathrm{Ta}-\mathrm{Sn}$ oxides with a trend from Type 2 CGM (columbite-(Fe)) + cassiterite $\rightarrow$ Type 3 CGM (columbite-(Mn)) $\rightarrow$ Type 4 CGM (tantalite-(Fe)) + ferrowodginite. The reversed Mn-Fe fractionation was likely due to the interaction between the pegmatite-forming melt and wallrock [52,57]. Although the triphylite is the Fe-Mn-richest mineral and abundant in No. 90 pegmatite, the low $\mathrm{Mn} /(\mathrm{Mn}+\mathrm{Fe})$ value $(<0.5)$ of this phase suggests that the crystallization of the triphylite cannot result in the reversed Mn-Fe fractionation. Moreover, from Type 3 CGM to Type 4 CGM + ferrowodginite, the compositional trend is characterized by significant increase in $\mathrm{Ti}, \mathrm{Sc}, \mathrm{Zr}, \mathrm{Hf}$, and $\mathrm{Sn}$ and slight decrease in $\mathrm{W}$, accompanied by decreased $\mathrm{Mn} / \mathrm{Fe}$. Titanium was likely added to the residual melt through the 
interaction with wallrock whereas the change in the $\mathrm{Zr}, \mathrm{Hf}$, and $\mathrm{W}$ concentrations of the $\mathrm{Nb}-\mathrm{Ta}-\mathrm{Sn}$ oxides was the result of magmatic fractionation. The sudden increase in the Sn activity during the formation of ferrowodginite at a late-stage was possibly related to the interaction between the residual melt and Sn-bearing fluids exsolved at an earlier stage.

Compared with No. 90 pegmatite, No. 503 and 91 pegmatites show relatively simple evolution of the Nb-Ta-Sn oxides. In No. 503 pegmatite, the crystallization sequence starts from Type 1 CGM to Type 2 CGM + cassiterite whereas in No. 91 pegmatite only Type 2 CGM + cassiterite is present. The composition of Type 2 CGM from No. 91 pegmatite changes to a Ta-Fe-richer composition, indicating that No. 91 pegmatite may also have experienced interaction with the wallrock.

Within the pegmatite group, Type 2 CGM (except the rim of Type 2 CGM from No. 91 pegmatite) from all three pegmatites shows comparable $\mathrm{Nb} / \mathrm{Ta}$ ratios. In contrast, the cassiterite coexisting with Type 2 CGM from the three pegmatites exhibits inconsistent $\mathrm{Nb} / \mathrm{Ta}$ ratios, indicating that the Type 2 CGM + cassiterite was likely formed under different physicochemical conditions (temperature, pressure, etc.). The cassiterite from different pegmatites also shows different $\mathrm{Zr} / \mathrm{Hf}$ and $\mathrm{Sn} / \mathrm{W}$ ratios. The $\mathrm{Sn} / \mathrm{W}$ ratios of the cassiterite is strongly influenced by the coexisting CGM. Moreover, the $\mathrm{Nb} / \mathrm{Ta}$ and $\mathrm{Zr} / \mathrm{Hf}$ ratios of the cassiterite display a positive correlation that mimics the $\mathrm{Nb}$ - $\mathrm{Ta}$ and $\mathrm{Zr}-\mathrm{Hf}$ fractionation in many LCT pegmatites. Therefore, these two ratios of cassiterite may bear meanings regarding the pegmatite evolution and are worth further investigation.

Supplementary Materials: The following are available online at http://www.mdpi.com/2075-163X/9/3/166/s1.

Author Contributions: Y.F. conceived of the presented idea, designed the experiments and verified the data along with T.L. The article is originally written and revised by the corresponding author, Y.F., T.L., the other corresponding author is also responsible for some key revisions. The financial support for this study was mainly secured by T.L., X.Y., Z.Z. and Y.W. along with the two corresponding authors conducted the fieldwork. Z.Z. digitalized the geological map and cross-section profile and performed EPMA and LA-ICP-MS analyses along with Y.F. and Y.W.

Funding: This study is financially supported by the Ministry of Science and Technology of the China granted to T. Liang (Grant Number: 2017YFC0602701) and the Fundamental Research Funds for the Central Universities of China to Y. Feng (Grant Number: 300102279101).

Acknowledgments: The authors would like to thank the three anonymous reviewers for their comments that help improve this manuscript significantly. The editors are thanked for their assistance with the manuscript processing. The authors are grateful to Yan Luan for the assistance with LA-ICP-MS analysis. The authors would like to thank the colleagues from Xi'an Center, the Geological Survey of China for fieldwork assistance.

Conflicts of Interest: The authors declare no conflict of interest.

\section{References}

1. Linnen, R.L.; Van Lichtervelde, M.; Černý, P. Granitic pegmatites as sources of strategic metals. Elements 2012, 8, 275-280. [CrossRef]

2. Linnen, R.L.; Samson, I.M.; Williams-Jones, A.E.; Chakhmouradian, A.R. Geochemistry of the rare-earth element, $\mathrm{Nb}$, Ta, Hf, and Zr deposits. In Treatise on Geochemistry, 2nd ed.; Holland, H.D., Turekian, K.K., Eds.; Elsevier: Oxford, UK, 2014; Volume 13, pp. 543-564.

3. Černý, P.; Ercit, T.S. Mineralogy of niobium and tantalum: Crystal chemical relationships, paragenetic aspects and their economic implications. In Lanthanides. Tantalum and Niobium; Möller, P., Černý, P., Saupé, F., Eds.; Springer: Berlin, Germany, 1989; pp. 27-79.

4. Černý, P.; Blevin, P.L.; Cuney, M.; London, D. Granite-related ore deposits. Econ. Geol. Anniv. 2005, 337-370.

5. Melcher, F.; Graupner, T.; Gäbler, H.-E.; Sitnikova, M.; Oberthür, T.; Gerdes, A.; Badanina, E.; Chudy, T. Mineralogical and chemical evolution of tantalum-(niobium-tin) mineralisation in pegmatites and granites. Part 2: Worldwide examples (excluding Africa) and an overview of global metallogenetic patterns. Ore Geol. Rev. 2017, 89, 946-987. [CrossRef]

6. Fosso Tchunte, P.M.; Tchameni, R.; André-Mayer, A.S.; Dakoure, H.S.; Turlin, F.; Poujol, M.; Negue Nomo, E.; Saha Fouotsa, A.N.; Rouer, O. Evidence for Nb-Ta Occurrences in the Syn-Tectonic Pan-African Mayo Salah Leucogranite (Northern Cameroon): Constraints from Nb-Ta Oxide Mineralogy, Geochemistry and U-Pb LA-ICP-MS Geochronology on Columbite and Monazite. Minerals 2018, 8, 188. [CrossRef] 
7. Melcher, F.; Graupner, T.; Gäbler, H.-E.; Sitnikova, M.; Henjes-Kunst, F.; Oberthür, T.; Gerdes, A.; Dewaele, S. Tantalum-(niobium-tin) mineralisation in African pegmatites and rare metal granites: Constraints from $\mathrm{Ta}-\mathrm{Nb}$ oxide mineralogy, geochemistry and U-Pb geochronology. Ore Geol. Rev. 2015, 64, 667-719. [CrossRef]

8. Badanina, E.V.; Sitnikova, M.A.; Gordienko, V.V.; Melcher, F.; Gäbler, H.E.; Lodziak, J.; Syritso, L.F. Mineral chemistry of columbite-tantalite from spodumene pegmatites of Kolmozero, Kola Peninsula (Russia). Ore Geol. Rev. 2015, 64, 720-735. [CrossRef]

9. Černý, P.; Ercit, T.S. Some recent advances in the mineralogy and geochemistry of $\mathrm{Nb}$ and Ta in rare-element granitic pegmatites. Bull. Minéral. 1985, 108, 499-532.

10. Černý, P.; Goad, B.E.; Hawthorne, F.C.; Chapman, R. Fractionation trends of the Nb- and Ta-bearing oxide minerals in the Greer Lake pegmatitic granite and its pegmatite aureole, southeastern Manitoba. Am. Mineral. 1986, 71, 501-517.

11. Tindle, A.G.; Breaks, F.W. Columbite-tantalite mineral chemistry from rare-element granitic pegmatites: Separation Lake area, N.W. Ontario, Canada. Mineral. Petrol. 2000, 70, 165-198. [CrossRef]

12. Pal, D.C.; Mishra, B.; Bernhardt, H. Mineralogy and geochemistry of pegmatite-hosted Sn-, Ta-Nb-, and Zr-Hf-bearing minerals from the southeastern part of the Bastar-Malkangiri pegmatite belt, Central India. Ore Geol. Rev. 2007, 30, 30-55. [CrossRef]

13. Breiter, K.; Skoda, R.; Uher, P. Nb-Ta-Ti-W-Sn-oxide minerals as indicators of a peraluminous P-and F-rich granitic system evolution: Podlesí, Czech Republic. Mineral. Petrol. 2007, 91, 225-248. [CrossRef]

14. Llorens, T.; Moro, M.C. Oxide minerals in the granitic cupola of the Jálama Batholith, Salamanca, Spain. Part I: Accessory Sn, Nb, Ta and Ti minerals in leucogranites, aplites and pegmatites. J. Geosci. 2012, 57, $25-43$. [CrossRef]

15. Plimer, I.R.; Lu, J.; Kleeman, J.D. Trace and rare earth elements in cassiterite-Sources of components for the tin deposits of the Mole Granite, Australia. Miner. Depos. 1991, 26, 267-274. [CrossRef]

16. Neiva, M.R. Geochemistry of cassiterite and its inclusion and exsolution products from tin and tungsten deposits in Portugal. Can. Mineral. 1996, 34, 745-768.

17. Neiva, A.M.R. Geochemistry of cassiterite and wolframite from tin and tungsten quartz veins in Portugal. Ore Geol. Rev. 2008, 33, 221-238. [CrossRef]

18. Xie, L.; Wang, R.-C.; Che, X.-D.; Huang, F.-F.; Erdmann, S.; Zhang, W.-L. Tracking magmatic and hydrothermal $\mathrm{Nb}-\mathrm{Ta}-\mathrm{W}-\mathrm{Sn}$ fractionation using mineral textures and composition: A case study from the late Cretaceous Jiepailing ore district in the Nanling Range in South China. Ore Geol. Rev. 2016, 78, 300-321.

19. Černý, P.; Ercit, T.S.; Smeds, S.-A.; Groat, L.A.; Chapman, R. Zirconium and hafnium in minerals of the columbite and wodginite groups from granitic pegmatites. Can. Mineral. 2007, 45, 185-202. [CrossRef]

20. Zhou, B.; Sun, Y.X.; Kong, D.Y. Geological features and prospecting potential of rare metallic deposits in the Dahongliutan region, Xinjiang. Acta Geol. Sichuan 2011, 31, 288-292. (In Chinese)

21. Yan, Q.-H.; Qiu, Z.-W.; Wang, H.; Wang, M.; Wei, X.-P.; Li, P.; Zhang, R.-Q.; Li, C.-Y.; Liu, J.P. Age of the Dahongliutan rare metal pegmatite deposit, West Kunlun, Xinjiang (NW China): Constraints from LA-ICP-MS U-Pb dating of columbite-(Fe) and cassiterite. Ore Geol. Rev. 2016. [CrossRef]

22. Černý, P.; Ercit, T.S. The classification of granitic pegmatites revisited. Can. Mineral. 2005, 43, $2005-2026$. [CrossRef]

23. Xiao, W.J.; Han, F.L.; Windley, B.F.; Yuan, C.; Zhou, H.; Li, J.L. Multiple accretionary orogenesis and episodic growth of continents: Insights from the western Kunlun Range, Central Asia. Int. Geol. Rev. 2003, 45, 303-328. [CrossRef]

24. Xiao, W.J.; Windley, B.F.; Liu, D.Y.; Jian, P.; Liu, C.Z.; Yuan, C.; Sun, M. Accretionary tectonics of the Western Kunlun orogen, China: A Paleozoic-Early Mesozoic, long lived active continental margin with implications for the growth of southern Eurasia. J. Geol. 2005, 113, 687-705. [CrossRef]

25. Hu, J.; Wang, H.; Huang, C.Y.; Tong, L.X.; Mu, S.L.; Qiu, Z.W. Geological characteristics and age of the Dahongliutan Fe-ore deposit in the Western Kunlun orogenic belt, Xinjiang, northwestern China. J. Asian Earth Sci. 2015, 116, 1-25. [CrossRef]

26. Deng, W.M. The geologic characteristics of the ophiolites in the Karakoram- West Kunlun region and their tectonic significance. Acta Petrol. Sin. 1995, 11, 98-111.

27. Yin, J.X.; Bian, Q.T. Geological Map of the Karakoram-West Kunlun and Adjacent Regions; Science Press: Beijing, China, 1995. 
28. Pan, Y.S. Geological Evolution of the Karakorum and Kunlun Mountains; Seismological Press: Beijing, China, 1996. (In Chinese)

29. Ding, D.G.; Wang, D.X.; Liu, W.X. The Western Kunlun Orogenic Belt and Basin; Geological Publishing House: Beijing, China, 1996; pp. 1-224. (In Chinese)

30. Mattern, F.; Schneider, W. Suturing of the Proto- and Paleo-Tethys oceans in the Western Kunlun (Xijiang, China). J. Asian Earth Sci. 2000, 18, 637-650. [CrossRef]

31. Huang, C.Y. Geological Characteristics and Genesis of the Iron Ore Deposit in the Bulunkuole Group, West Kunlun, Xinjiang. Ph.D. Thesis, Guangzhou Institute of Geochemistry Chinese Academy of Sciences, Guangdong, China, 2014. Unpublished (In Chinese)

32. Jiang, Y.H.; Jia, R.Y.; Liu, Z.; Liao, S.Y.; Zhao, P.; Zhou, P. Origin of middle Triassic high-K calc-alkaline granitoids and their potassic microgranular enclaves from the Western Kunlun orogen, northwest China: A record of the closure of Paleo Tethys. Lithos 2013, 156, 13-30. [CrossRef]

33. Xu, Z.; Qi, X.; Yang, J.; Ji, S.; Li, H.; Chen, F. Senses and timings of two kinds of shear in the Kangxiwar strike-slip shear zone, West Kunlun, and their tectonic significance. Geol. Bull. China 2007, 26, 1252-1261. (In Chinese)

34. Qiao, G.B.; Zhang, H.D.; Wu, Y.Z.; Jin, M.S.; Du, W.; Zhao, X.J.; Chen, D.H. Petrogenesis of the Dahongliutan monzogranite in western Kunlun: Constraints from SHRIMP zircon U-Pb geochronology and geochemical characteristics. Acta Geol. Sin. 2015, 89, 1180-1194. (In Chinese)

35. Wei, X.; Wang, H.; Hu, J.; Mu, S.; Qiu, Z.; Yan, Q.; Li, P. Geochemistry and geochronology of the Dahongliutan two-mica granite pluton in western Kunlun orogen: Geotectonic implications. Geochimica 2017, 46, 66-80. (In Chinese)

36. Li, S.Z.; Jahn, B.; Zhao, S.J.; Dai, L.M.; Li, X.Y.; Suo, Y.H.; Guo, L.L.; Wang, Y.M.; Liu, X.C.; Lan, H.Y.; et al. Triassic southeastward subduction of North China Block to South China Block: Insights from new geological, geophysical and geochemical data. Earth-Sci. Rev. 2017. [CrossRef]

37. London, D. Pegmatites; The Canadian Mineralogist; Special Publication: London, UK, 2008; p. 347.

38. Fransolet, A.M.; Keller, P.; Fontan, F. The phoshate mineral associations of the Tsaobismund pegmatite, Namibia. Contrib. Mineral. Petrol. 1986, 92, 502-517. [CrossRef]

39. Baijot, M.; Hatert, F.; Philippo, S. Mineralogy and geochemistry of phosphates and silicates in the Sapucaia pegmatite, Minas Gerais, Brazil: Genetic implications. Can. Mineral. 2012, 50, 1531-1554. [CrossRef]

40. Vignola, P.; Diella, V.; Oppizzi, P.; Tiepolo, M.; Weiss, S. Phosphate assemblages from the Brissago granitic pegmatite, western Southern Alps, Switzerland. Can. Mineral. 2008, 46, 635-650. [CrossRef]

41. Charoy, B.; Lhote, F.; Dusausoy, Y.; Noronha, F. The crystal chemistry of spodumene in some granitic aplite-pegmatite bodies of northern Portugal; a comparative review. Can. Mineral. 1992, 30, 639-651.

42. Hensen, B.J. Mineralogy and petrography of some tin, lithium and beryllium bearing albite-pegmatites near Doade, Galicia, Spain. Leidse Geol. Mededel. 1967, 39, 249-259.

43. Černý, P.; Ferguson, R.B. The Tanco pegmatite at Bernic Lake, Manitoba; IV, Petalite and spodumene relations. Can. Mineral. 1972, 11, 660-678.

44. Geisler, T.; Schaltegger, U.; Tomaschek, F. Re-equilibration of Zircon in Aqueous Fluids and Melts. Elements 2007, 3, 43-50. [CrossRef]

45. Černý, P. Exploration strategy and methods for pegmatite deposits of tantalum. In Lanthanides, Tantalum and Niobium; Springer: Berlin/Heidelberg, Germany, 1989; pp. 274-302.

46. Černý, P.; Chapman, R.; Ferreira, K.; Smeds, S.-A. Geochemistry of oxide minerals of Nb, Ta, Sn, and Sb in the Varuträsk granitic pegmatite, Sweden: The case of an "anomalous" columbite-tantalite trend. Am. Mineral. 2004, 89, 505-518. [CrossRef]

47. Tindle, A.G.; Breaks, F.W. Oxide minerals of the Separation Rapids rare-element granitic pegmatite group, northwestern Ontario. Can. Mineral. 1998, 36, 609-635.

48. Hatert, F.; Roda-Robles, E.; Ottolini, L.; Schmid-Beurmann, P.; Baijot, M.; Dal Bo, F. Triphylite-Sarcopside Miscibility Gap in the $\mathrm{FeO}-\mathrm{MnO}-\mathrm{Li}_{2} \mathrm{O}-\mathrm{P}_{2} \mathrm{O}_{5}-\mathrm{H}_{2} \mathrm{O}$ System: Experimental Investigation and Thermometric Application to Granitic Pegmatites. Can. Mineral. 2016, 54, 827-845. [CrossRef]

49. Akoh, J.U.; Ogunleye, P.O.; Ibrahim, A.A. Geochemical evolution of micas and Sn-, Nb-, Ta-mineralization associated with the rare metal pegmatite in Angwan Doka, central Nigeria. J. Afr. Earth Sci. 2015, 112, $24-36$. [CrossRef] 
50. Dewaele, S.; Hulsbosch, N.; Cryns, Y.; Boyce, A.; Burgess, R.; Muchez, P. Geological setting and timing of the world-class $\mathrm{Sn}, \mathrm{Nb}-\mathrm{Ta}$ and Li mineralization of Manono-Kitotolo (Katanga, Democratic Republic of Congo). Ore Geol. Rev. 2016, 72, 373-390. [CrossRef]

51. Van Lichtervelde, M.; Salvi, S.; Beziat, D.; Linnen, R.L. Textural features and chemical evolution in tantalum oxides: Magmatic versus hydrothermal origins for Ta mineralization in the Tanco Lower pegmatite, Manitoba, Canada. Econ. Geol. 2007, 102, 257-276. [CrossRef]

52. Tindle, A.G.; Breaks, F.W.; Webb, P.C. Wodginite-group minerals from the Separation Rapids rare-element granitic pegmatite group, northwestern Ontario. Can. Mineral. 1998, 36, 637-658.

53. Linnen, R.; Cuney, M. Granite-related rare-element deposits and experimental constraints on $\mathrm{Ta}-\mathrm{Nb}-\mathrm{W}-\mathrm{Sn}-\mathrm{Zr}-\mathrm{Hf}$ mineralization. In Rare-Element Geochemistry and Mineral Deposits; GAC Short Course Notes 17; Geological Association of Canada: Ottawa, ON, Canada, 2005; pp. 45-68.

54. Van Lichtervelde, M.; Holtz, F.; Melcher, F. The effect of disequilibrium crystallization on Nb-Ta fractionation in pegmatites: Constraints from crystallization experiments of tantalite-tapiolite. Am. Mineral. J. Earth Planet. Mater. 2018, 103, 1401-1416. [CrossRef]

55. Möller, P.; Dulski, P. Fractionation of Zr and Hf in cassiterite. Chem. Geol. 1983, 40, 1-12. [CrossRef]

56. Möller, P.; Dulski, P.; Szacki, W.; Malow, G.; Riedel, E. Substitution of tin in cassiterite by tantalum, niobium, tungsten, iron and manganese. Geochim. Cosmochim. Acta 1988, 52, 1497-1503. [CrossRef]

57. Galliski, M.A.; Marquez-Zavalía, M.F.; Cerný, P.; Martínez, V.A.; Chapman, R. The Ta-Nb-Sn-Ti oxide-mineral paragenesis from La Viquita, a spodumene-bearing rare-element granitic pegmatite, San Luis, Argentina. Can. Mineral. 2008, 46, 379-393. [CrossRef]

58. Novak, M.; Černý, P. Niobium-tantalum oxide minerals from complex granitic pegmatites in the Moldanubicum, Czech Republic; primary versus secondary compositional trends. Can. Mineral. 1998, 36, 659-672.

59. Černý, P.; Němec, D. Pristine vs. contaminated trends in Nb, Ta-oxide minerals of the Jihlava pegmatite district, Czech Republic. Mineral. Petrol. 1995, 55, 117-129.

60. Wise, M.A.; Černý, P.; Falster, A.U. Scandium substitution in columbite-group minerals and ixiolite. Can. Mineral. 1998, 36, 673-680.

61. Linnen, R.L. Discussion on change in Sn activity and formation of wodginite-group minerals during pegmatite evolution. Personal communication, 30 January 2019.

62. Linnen, R.L. Depth of emplacement, fluid provenance and metallogeny in granitic terranes: A comparison of western Thailand with other tin belts. Miner. Depos. 1998, 33, 461-476. [CrossRef] 